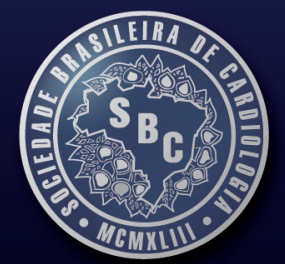

Arquivos Brasileiros de
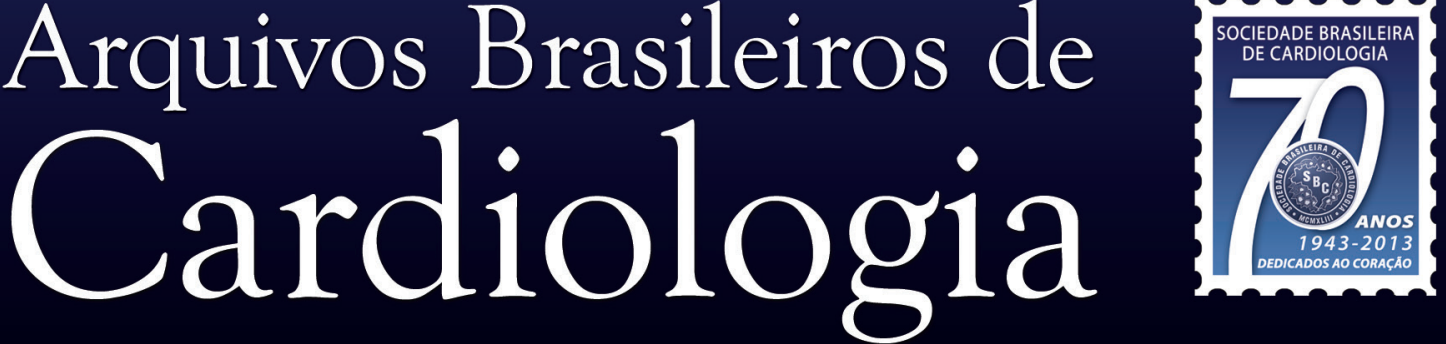

www.cardiol.br

Sociedade Brasileira de Cardiologia •ISSN-0066-782X • Volume 100, № 4, Supl. 1, Abril 2013

www.arquivosonline.com.br

\title{
I Diretriz Brasileira de Miocardites e Pericardites
}




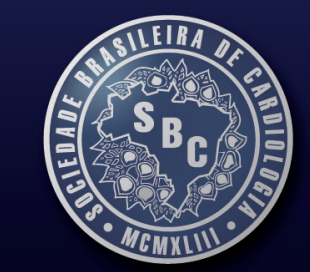

\section{Arquivos Brasileiros de}

www.cardiol.br

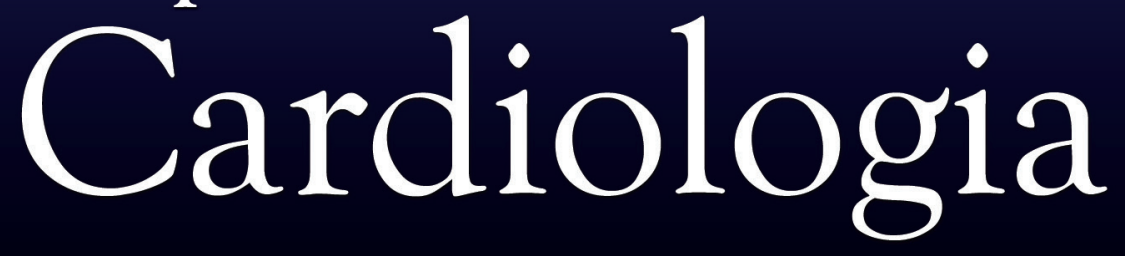

\section{Diretriz Brasileira de Miocardites e Pericardites}

\section{Autores da Diretriz:}

Montera M.W., Mesquita E.T., Colafranceschi A.S., Oliveira Junior A.M., Rabischoffsky A., lanni B.M., Rochitte C.E, Mady C., Mesquita C.T., Azevedo C.F., Bocchi E.A., Saad E.B., Braga F.G.M, Fernandes F., Ramires F.J.A., Bacal F., Feitosa G.S., Figueira H.R., Souza Neto J.D., Moura L.A.Z., Campos L.A.A., Bittencourt M.I., Barbosa M.M., Moreira M.C.V., Higuchi M.L., Schwartzmann P., Rocha R.M., Pereira S.B., Mangini S., Martins S.M., Bordignon S., Salles V.A. 


\section{www.cardiol.br}

\section{Arquivos Brasileiros de Cardiologia}

\section{Diretor Científico}

Luiz Alberto Piva e Mattos

\section{Editor-Chefe \\ Luiz Felipe P. Moreira}

Editores Associados

Cardiologia Clínica

José Augusto Barreto-Filho

Cardiologia Cirúrgica

Paulo Roberto B. Evora

\author{
CARDiologia InTERVENCIONISTA \\ Pedro A. Lemos
}

Cardiologia Pediátrica/Congênitas

Antonio Augusto Lopes

Arritmias/Marcapasso

Mauricio Scanavacca

Métodos Diagnósticos Não-Invasivos Carlos E. Rochitte

Pesquisa Básica ou Experimental

Leonardo A. M. Zornoff

\author{
Epidemiologia/Estatística \\ Lucia Campos Pellanda
}

Hipertensão Arterial

Paulo Cesar B. V. Jardim

\section{Ergometria, Exercício e \\ Reabilitação Cardíaca \\ Ricardo Stein}

Primeiro Editor (1948-1953)

+ Jairo Ramos

\section{Conselho Editorial}

\section{Brasil}

Adib D. Jatene (SP)

Alexandre A. C. Abizaid (SP)

Alfredo José Mansur (SP)

Álvaro Avezum (SP)

Amanda G. M. R. Sousa (SP)

André Labrunie (PR)

Andrei Sposito (DF)

Angelo A. V. de Paola (SP)

Antonio Augusto Barbosa Lopes (SP)

Antonio Carlos C. Carvalho (SP)

Antônio Carlos Palandri Chagas (SP)

Antonio Carlos Pereira Barretto (SP)

Antonio Cláudio L. Nóbrega (RJ)

Antonio de Padua Mansur (SP)

Ari Timerman (SP)

Armênio Costa Guimarães (BA)

Ayrton Klier Péres (DF)

Ayrton Pires Brandão (RJ)

Barbara M. lanni (SP)

Beatriz Matsubara (SP)

Braulio Luna Filho (SP)

Brivaldo Markman Filho (PE)

Bruce B. Duncan (RS)

Bruno Caramelli (SP)

Carisi A. Polanczyk (RS)

Carlos Alberto Pastore (SP)

Carlos Eduardo Negrão (SP)

Carlos Eduardo Rochitte (SP)

Carlos Eduardo Suaide Silva (SP)

Carlos Vicente Serrano Júnior (SP)

Celso Amodeo (SP)

Charles Mady (SP)

Claudio Gil Soares de Araujo (RJ)

Cleonice Carvalho C. Mota (MG)

Dalton Valentim Vassallo (ES)

Décio Mion Jr (SP)

Denilson Campos de Albuquerque (RJ)

Dikran Armaganijan (SP)

Djair Brindeiro Filho (PE)

Domingo M. Braile (SP)

Edmar Atik (SP)

Edson Stefanini (SP)

Elias Knobel (SP)

Eliudem Galvão Lima (ES)

Emilio Hideyuki Moriguchi (RS)

Enio Buffolo (SP)

\section{Eulógio E. Martinez Fo (SP)}

Evandro Tinoco Mesquita (RJ)

Expedito E. Ribeiro da Silva (SP)

Fábio Sândoli de Brito Jr. (SP)

Fábio Vilas-Boas (BA)

Fernando A. P. Morcerf (RJ)

Fernando Bacal (SP)

Flávio D. Fuchs (RS)

Francisco Antonio Helfenstein Fonseca (SP)

Francisco Laurindo (SP)

Francisco Manes Albanesi Fo (RJ)

Gilmar Reis (MG)

Gilson Soares Feitosa (BA)

Ínes Lessa (BA)

Iran Castro (RS)

Ivan G. Maia (RJ)

Ivo Nesralla (RS)

Jarbas Jakson Dinkhuysen (SP)

João Pimenta (SP)

Jorge Ilha Guimarães (RS)

Jorge Pinto Ribeiro (RS)

José A. Marin-Neto (SP)

José Antonio Franchini Ramires (SP)

José Augusto Soares Barreto Filho (SE)

José Carlos Nicolau (SP)

José Geraldo de Castro Amino (RJ)

José Lázaro de Andrade (SP)

José Péricles Esteves (BA)

José Teles Mendonça (SE)

Leopoldo Soares Piegas (SP)

Luís Eduardo Rohde (RS)

Luiz A. Machado César (SP)

Luiz Alberto Piva e Mattos (SP)

Lurildo Saraiva (PE)

Marcelo C. Bertolami (SP)

Marcia Melo Barbosa (MG)

Marco Antônio Mota Gomes (AL)

Marcus V. Bolívar Malachias (MG)

Maria Cecilia Solimene (SP)

Mario S. S. de Azeredo Coutinho (SC)

Maurício I. Scanavacca (SP)

Mauricio Wajngarten (SP)

Max Grinberg (SP)

Michel Batlouni (SP)

Nabil Chorayeb (SP)

Nadine O. Clausell (RS)

Nelson Souza e Silva (RJ)
Orlando Campos Filho (SP)

Otávio Rizzi Coelho (SP)

Otoni Moreira Gomes (MG)

Paulo A. Lotufo (SP)

Paulo Cesar B. V. Jardim (GO)

Paulo J. F. Tucci (SP)

Paulo J. Moffa (SP)

Paulo R. A. Caramori (RS)

Paulo R. F. Rossi (PR)

Paulo Roberto S. Brofman (PR)

Paulo Zielinsky (RS)

Protásio Lemos da Luz (SP)

Renato A. K. Kalil (RS)

Roberto A. Franken (SP)

Roberto Bassan (RJ)

Ronaldo da Rocha Loures Bueno (PR)

Sandra da Silva Mattos (PE)

Sergio Almeida de Oliveira (SP)

Sérgio Emanuel Kaiser (RJ)

Sergio G. Rassi (GO)

Sérgio Salles Xavier (RJ)

Sergio Timerman (SP)

Silvia H. G. Lage (SP)

Valmir Fontes (SP)

Vera D. Aiello (SP)

Walkiria S. Avila (SP)

William Azem Chalela (SP)

Wilson A. Oliveira Jr (PE)

Wilson Mathias Jr (SP)

\section{Exterior}

Adelino F. Leite-Moreira (Portugal)

Alan Maisel (Estados Unidos)

Aldo P. Maggioni (Itália)

Cândida Fonseca (Portugal)

Fausto Pinto (Portugal)

Hugo Grancelli (Argentina)

James de Lemos (Estados Unidos)

João A. Lima (Estados Unidos)

John G. F. Cleland (Inglaterra)

Maria Pilar Tornos (Espanha)

Pedro Brugada (Bélgica)

Peter A. McCullough (Estados Unidos)

Peter Libby (Estados Unidos)

Piero Anversa (Itália) 


\section{Sociedade Brasileira de Cardiologia}

Presidente

Jadelson Pinheiro de Andrade

Vice-Presidente

Dalton Bertolim Précoma

Presidente-Eleito

Angelo Amato Vincenzo de Paola

Diretor Administrativo

Marcelo Souza Hadlich

Diretora Financeira

Eduardo Nagib Gaui

Diretor de Relações Governamentais

Daniel França Vasconcelos

Diretor de Comunicação

Carlos Eduardo Suaide Silva

Diretor de Qualidade Assistencial José Xavier de Melo Filho

Diretor Científico

Luiz Alberto Piva e Mattos

Diretor de Promoção de Saúde

Cardiovascular - SBC/Funcor

Carlos Alberto Machado

Diretor de Relações

Estaduais e Regionais

Marco Antonio de Mattos

Diretor de Departamentos

Especializados

Gilberto Venossi Barbosa

Diretor de Tecnologia da Informação

Carlos Eduardo Suaide Silva

Diretor de Pesquisa

Fernando Bacal

Editor-Chefe Arquivos Brasileiros de Cardiologia

Luiz Felipe P. Moreira
Editor do Jornal SBC

Fábio Vilas-Boas Pinto

Coordenador do Conselho de Projeto

Epidemiológico

David de Padua Brasil

Coordenadores do Conselho de Ações Sociais

Alvaro Avezum Junior

Ari Timerman

Coordenadora do Conselho de Novos Projetos Glaucia Maria Moraes Oliveira

Coordenador do Conselho de Aplicação de

Novas Tecnologias

Washington Andrade Maciel

Coordenador do Conselho de Inserção do Jovem Cardiologista

Fernando Augusto Alves da Costa

Coordenador do Conselho de Avaliação da Qualidade da Prática Clínica e Segurança do Paciente

Evandro Tinoco Mesquita

Coordenador do Conselho de

Normatizações e Diretrizes

Harry Correa Filho

Coordenador do Conselho de Educação

Continuada

Antonio Carlos de Camargo Carvalho

Comitê de Atendimento de Emergência e Morte Súbita

Manoel Fernandes Canesin

Nabil Ghorayeb

Sergio Timerman

Comitê de Prevenção Cardiovascular Antonio Delduque de Araujo Travessa Sergio Baiocchi Carneiro

Regina Coeli Marques de Carvalho

Comitê de Planejamento Estratégico

Fabio Sândoli de Brito

José Carlos Moura Jorge

Walter José Gomes

Comitê de Assistência ao Associado

Maria Fatima de Azevedo

Mauro José Oliveira Goncalves

Ricardo Ryoshim Kuniyoshi
Comitê de Relações Internacionais

Antonio Felipe Simão

João Vicente Vitola

Oscar Pereira Dutra

Presidentes das Estaduais e Regionais da SBC

SBC/AL - Alfredo Aurelio Marinho Rosa

SBC/AM - Jaime Giovany Arnez Maldonado

SBC/BA - Augusto José Gonçalves de Almeida

SBC/CE - Eduardo Arrais Rocha

SBC/CO - Hernando Eduardo Nazzetta (GO)

SBC/DF - Renault Mattos Ribeiro Junior

SBC/ES - Antonio Carlos Avanza Junior

SBC/GO - Luiz Antonio Batista de Sá

SBC/MA - Magda Luciene de Souza Carvalho

SBC/MG - Maria da Consolação Vieira

Moreira

SBC/MS - Sandra Helena Gonsalves de Andrade

SBC/MT - José Silveira Lage

SBC/NNE - Aristoteles Comte de Alencar Filho (AM)

SBC/PA - Claudine Maria Alves Feio

SBC/PB - Alexandre Jorge de Andrade Negri

SBC/PE - Silvia Marinho Martins

SBC/PI - Ricardo Lobo Furtado

SBC/PR - Álvaro Vieira Moura

SBC/RJ - Glaucia Maria Moraes Oliveira

SBC/RN - Carlos Alberto de Faria

SBC/RS - Justo Antero Sayão Lobato Leivas

SBC/SC - Conrado Roberto Hoffmann Filho

SBC/SE - Eduardo José Pereira Ferreira

SBC/SP - Carlos Costa Magalhães

SBC/TO - Adalgele Rodrigues Blois

\section{Presidentes dos Departamentos Especializados e Grupos de Estudos}

SBC/DA - Hermes Toros Xavier (SP)

SBC/DCC - Evandro Tinoco Mesquita (RJ)

SBC/DCM - Orlando Otavio de

Medeiros (PE)

SBC/DCC/CP - Estela Suzana Kleiman Horowitz (RS)

SBC/DECAGE - Abrahão Afiune Neto (GO)

SBC/DEIC - João David de Souza Neto (CE)

SBC/DERC - Pedro Ferreira de

Albuquerque $(\mathrm{AL})$
SBC/DFCVR - José Carlos Dorsa Vieira Pontes (MS)

SBC/DHA - Weimar Kunz Sebba Barroso de Souza (GO)

SBC/DIC - Jorge Eduardo Assef (SP)

SBC/SBCCV - Walter José Gomes (SP)

SBC/SBHCI - Marcelo Antonio Cartaxo Queiroga Lopes (PB)

SBC/SOBRAC - Adalberto Menezes Lorga Filho (SP)

SBC/DCC/GAPO - Daniela Calderaro (SP)
SBC/DCC/GECETI - João Fernando Monteiro Ferreira (SP)

SBC/DCC/GEECABE - Luis Claudio Lemos Correia (BA)

SBC/DCC/GEECG - Carlos Alberto Pastore (SP)

SBC/DCP/GECIP - Angela Maria Pontes Bandeira de Oliveira (PE)

SBC/DERC/GECESP - Daniel Jogaib Daher (SP)

SBC/DERC/GECN - José Roberto Nolasco de Araújo (AL) 


\section{Arquivos Brasileiros de Cardiologia}

Volume 100, N 4, Suplemento 1, Abril 2013

Indexação: ISI (Thomson Scientific), Cumulated Index Medicus (NLM), SCOPUS, MEDLINE, EMBASE, LILACS, SciELO, PubMed

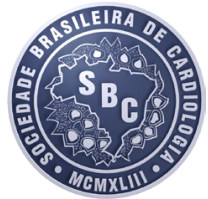

Av. Marechal Câmara, 160 - 3o andar - Sala 330 20020-907 • Centro • Rio de Janeiro, RJ • Brasil

Tel.: (21) 3478-2700

E-mail: arquivos@cardiol.br

www.arquivosonline.com.br

SciELO: www.scielo.br

\section{Departamento Comercial \\ Telefone: (11) 3411-5500}

e-mail: comercialsp@cardiol.br

\section{Produção Editorial}

SBC - Núcleo Interno de Publicações
Produção Gráfica e Diagramação

SBC - Núcleo Interno de Design

Impressão

Prol Editora Gráfica

Tiragem

11.000 exemplares

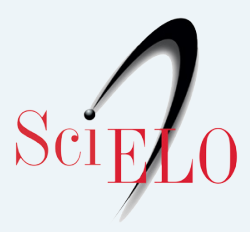

AMB

Filiada à Associação Médica Brasileira
Os anúncios veiculados nesta edição são de exclusiva responsabilidade dos anunciantes, assim como os conceitos emitidos em artigos assinados são de exclusiva responsabilidade de seus autores, não refletindo necessariamente a opinião da SBC.

Material de distribuição exclusiva à classe médica. Os Arquivos Brasileiros de Cardiologia não se responsabilizam pelo acesso indevido a seu conteúdo e que contrarie a determinação em atendimento à Resolução da Diretoria Colegiada (RDC) no 96/08 da Agência Nacional de Vigilância Sanitária (Anvisa), que atualiza o regulamento técnico sobre Propaganda, Publicidade, Promoção e informação de Medicamentos. Segundo o artigo 27 da insígnia, "a propaganda ou publicidade de medicamentos de venda sob prescrição deve ser restrita, única e exclusivamente, aos profissionais de saúde habilitados a prescrever ou dispensar tais produtos (...)".

Garantindo o acesso universal, o conteúdo científico do periódico continua disponível para acesso gratuito e integral a todos os interessados no endereço: www.arquivosonline.com.br.

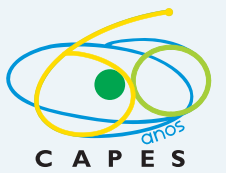

\section{Ministério da \\ Educação}

\section{Ministério da Ciência e Tecnologia}

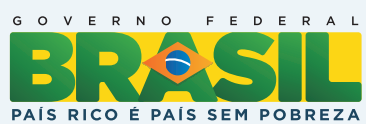




\section{Sumário}

\section{Miocardites}

1. Epidemiologia .................................................................................................................. página 1

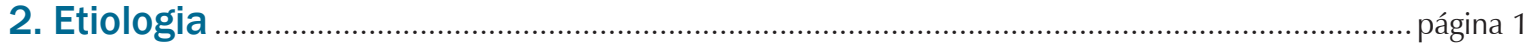

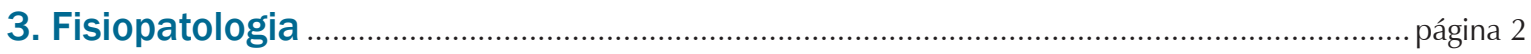

4. Diagnóstico

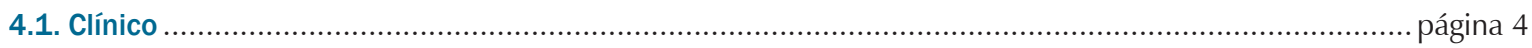

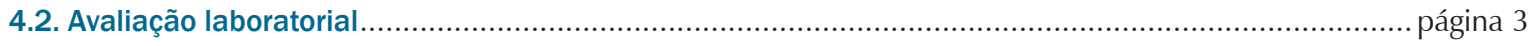

4.2.1. Marcadores laboratoriais de agressão inflamatória.............................................................. página 3

4.2.2. Marcadores laboratoriais de pesquisa etiopatogênica ..................................................... página 4

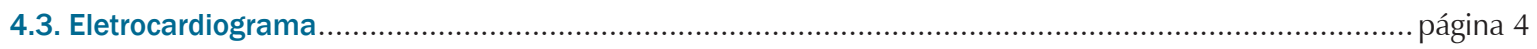

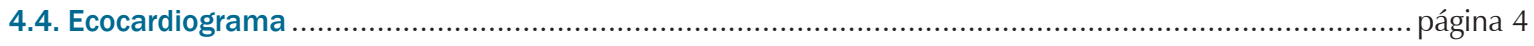

4.5. Ressonância magnética cardíaca................................................................................... página 4

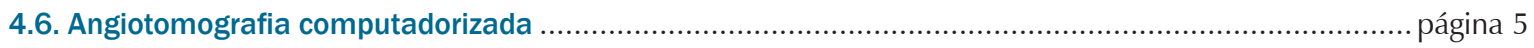

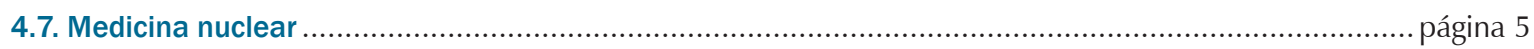

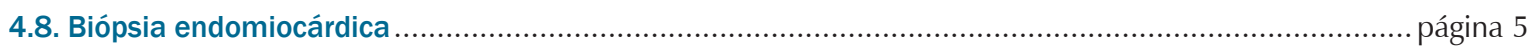

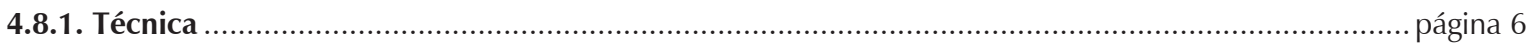

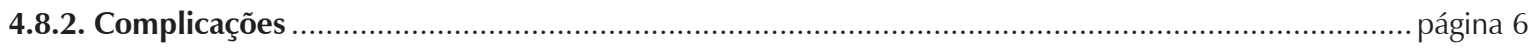

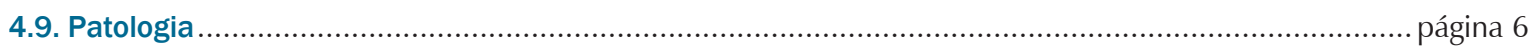

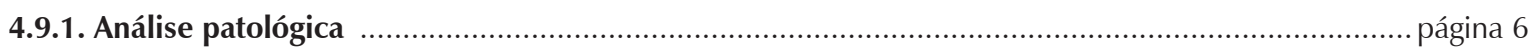

4.9.2. Análise histológica por imunohistoquímica .................................................................... página 7

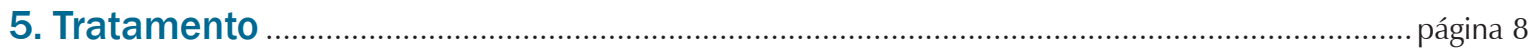

5.1. Medidas gerais e preventivas: hábitos de vida, exercício e dieta................................................... página 8

5.2. Suporte terapêutico geral: betabloqueadores, IECA/BRA, anti-coagulação ..................................... página 8

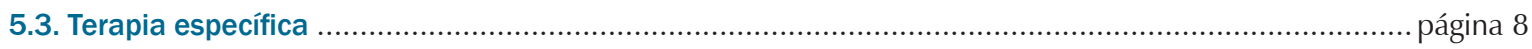

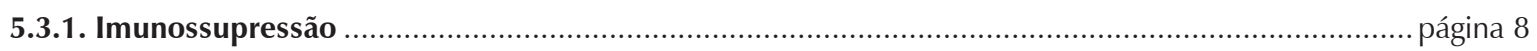

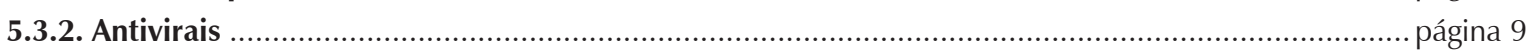

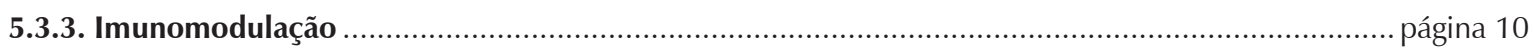

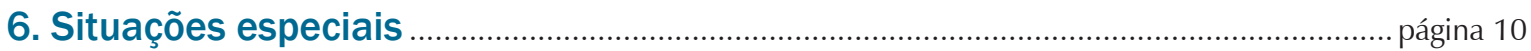

6.1. Tratamento de arritmias e prevenção da morte súbita ............................................................... página 10

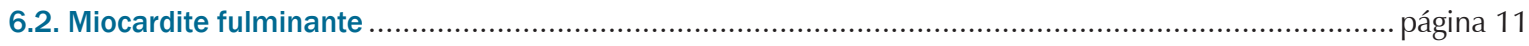

6.3. Cardiomiopatia neuro-adrenérgica (Takotsubo) ...................................................................... página 12

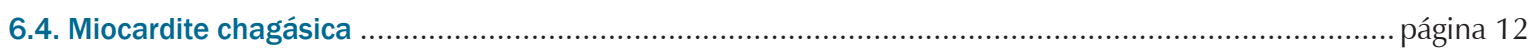

7. Avaliação prognóstica .................................................................................................... página 13

\section{Pericardites}

1. Epidemiologia .............................................................................................................. página 14

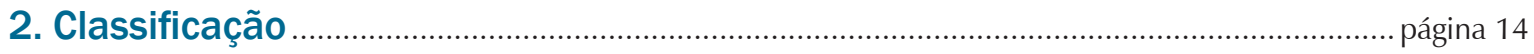

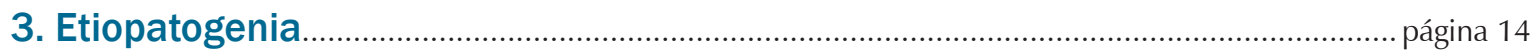

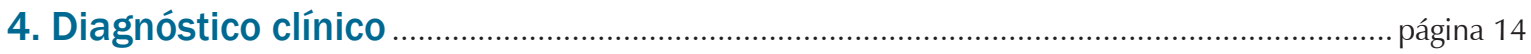


4.1. Pericardite aguda

página 14

4.2. Tamponamento cardíaco

página 15

4.3. Pericardite constritiva

página 16

4.4. Marcadores laboratoriais

página 16

4.4.1. Marcadores de atividade de doença

página 16

a) Marcadores de necrose miocárdica

página 16

b) Marcadores de atividade inflamatória

página 16

c) BNP / NT-proBNP

página 16

4.4.2. Marcadores do diagnóstico etiológico …....................................................................... página 16

4.5. Eletrocardiograma

página 16

4.6. Radiografia

página 17

4.7. Ecocardiograma

página 17

4.7.1. Derrame pericárdico

página 17

4.7.2. Tamponamento cardíaco

página 17

4.7.3. Pericardite constritiva

página 18

4.8. Tomografia computadorizada do coração (TCC) ...................................................................... página 18

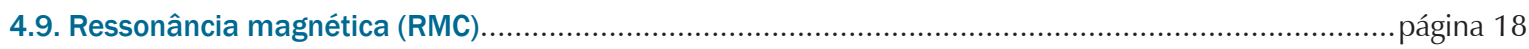

4.10. Medicina nuclear

página 18

4.11. Pericardiocentese e biópsia pericárdica ........................................................................página 19

4.12. Análise Histológica

página 20

\section{Tratamento}

página 20

5.1. Anti-inflamatórios não hormonais e colchicina

página 20

5.2. Imunossupressão

página 21

5.3. Antiviral.

página 21

5.4. Tratamento no tamponamento cardíaco ...............................................................................página 22

5.5. Tratamento cirúrgico das afecções pericárdicas.................................................................... página 22

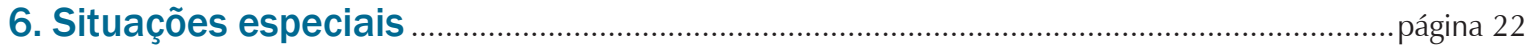

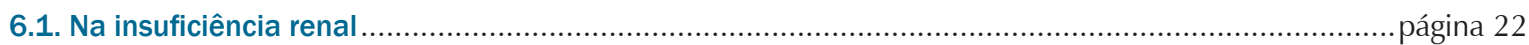

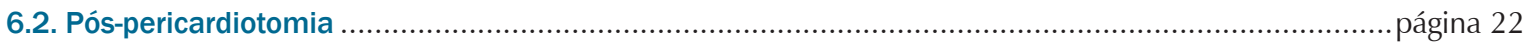

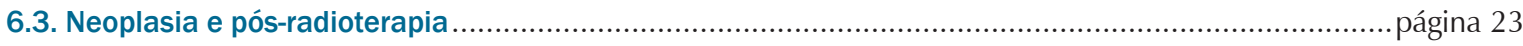

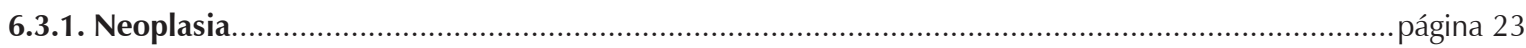

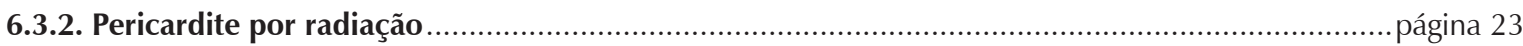

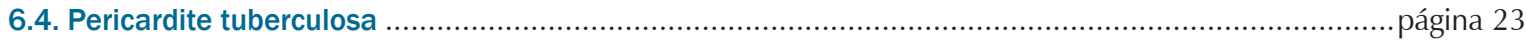

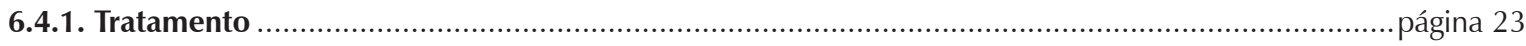

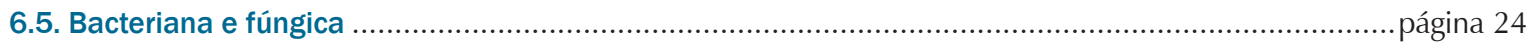

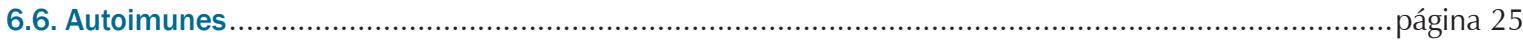

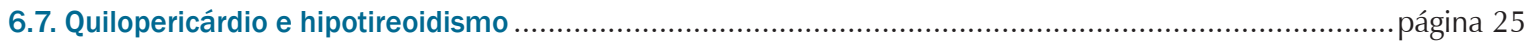

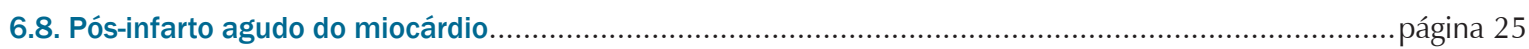

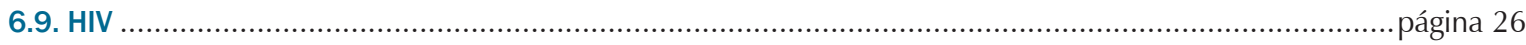

6.10. Pós-traumática e por dissecção aórtica................................................................................. página 26

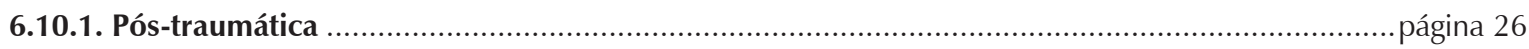

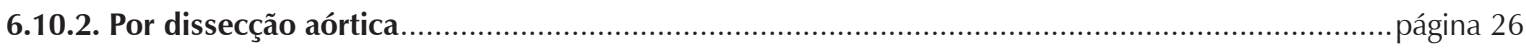

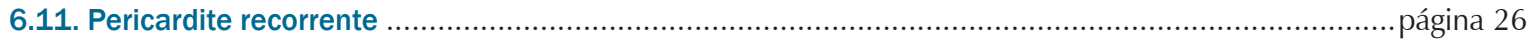

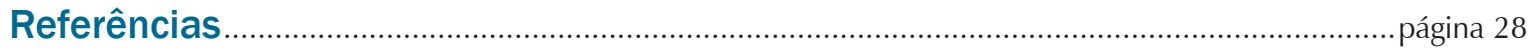


 \\ I Diretriz Brasileira de Miocardites e Pericardites}

REALIzAÇÃo

Sociedade Brasileira de Cardiologia

Coordenador de Normatizações e Diretrizes da SBC

Harry Correa Filho

Coordenadores da Diretriz

Marcelo Westerlund Montera

\section{Comissão de Redação e Planejamento}

Sabrina Bernardez Pereira, Vitor Agueda Salles e Pedro Schwartzmann

\section{Autores}

Marcelo Westerlund Montera (1), Evandro Tinoco Mesquita (1,2), Alexandre Siciliano Colafranceschi (1), Amarino Carvalho de Oliveira Jr. (1), Arnaldo Rabischoffsky (1), Barbara Maria lanni (3), Carlos Eduardo Rochitte (1,3,4), Charles Mady (1), Claudio Tinoco Mesquita (1,2), Clerio Francisco Azevedo (5), Edimar Alcides Bocchi (3), Eduardo Benchimol Saad (1), Fabiana Goulart Marcondes Braga (3), Fábio Fernandes (3), Felix José Alvarez Ramires (3), Fernando Bacal (3), Gilson Soares Feitosa (6), Hélio Roque Figueira (7,8), João David de Souza Neto (9), Lídia Ana Zytynski Moura (10,11), Luiz Antônio de Almeida Campos $(12,13)$, Marcelo Imbroinise Bittencourt (1,12), Márcia de Melo Barbosa (14), Maria da Consolação Vieira Moreira (15), Maria de Lourdes Higuchi (3), Pedro Schwartzmann (16), Ricardo Mourilhe Rocha (1,12), Sabrina Bernardez Pereira (2), Sandrigo Mangini $(3,17)$, Silvia Marinho Martins (18), Solange Bordignon $(19,20)$, Vitor Agueda Salles $(21,22)$.

\section{INSTITUIÇÕES}

1. Hospital Pró-Cardíaco; 2. Universidade Federal Fluminense; 3. Instituto do Coração - FMUSP; 4. Hospital do Coração - HCOR; 5. Labs D’Or - Grupo Fleury / Instituto D’Or de Pesquisa e Ensino; 6. Hospital Santa Izabel da Santa Casa de Misericórdia da Bahia; 7. Hospital TotalCor; 8. Clínica São Vicente; 9. Hospital de Messejana Dr. Carlos Alberto Studart Gomes; 10. Santa Casa de Curitiba; 11. Pontificia Universidade Católica do Paraná; 12. Universidade do Estado do Rio de Janeiro - UERJ; 13. Hospital Unimed-Rio; 14. Ecocenter - Hospital SOCOR (MG); 15. Faculdade de Medicina da Universidade Federal de Minas Gerais; 16. Hospital das Clínicas da Faculdade de Medicina de Ribeirão Preto - USP; 17. Hospital Israelita Albert Einstein; 18. Pronto-Socorro Cardiológico de Pernambuco, Universidade de Pernambuco; 19. Instituto de Cardiologia, Fundação Universitária de Cardiologia (RS); 20. Hospital Nossa Senhora da Conceição; 21. Instituto Nacional de Cardiologia; 22. Hospital Federal dos Servidores do Estado (RJ).

REVISORES

Antonio Carlos Sobral Sousa, Harry Correa Filho, Iran Castro, Marcus Vinicius Bolívar Malachias e Mario Sergio de Carvalho Bacellar

Esta diretriz deverá ser citada como:

Montera M.W., Mesquita E.T., Colafranceschi A.S., Oliveira Junior A.M., Rabischoffsky A., lanni B.M., et al. Sociedade Brasileira de Cardiologia. I Diretriz Brasileira de Miocardites e Pericardites. Arq Bras Cardiol 2013; 100(4 supl. 1): 1-36

\section{Correspondência:}

Marcelo W. Montera

Rua Dona Mariana, 209 - $2^{\circ}$ andar - Botafogo - Rio de Janeiro

Cep: 22280-020. E-mail: mmontera@uol.com.br 


\section{Diretrizes}

Declaração de potencial conflito de interesses dos autores/colaboradores da Alterar para: Diretriz em Cardiologia do Esporte - Avaliação pré-participação, prevenção de eventos e morte súbita em esportes, no lazer e nos paratletas

Se nos últimos 3 anos o autor/colaborador das Diretrizes:

\begin{tabular}{|c|c|c|c|c|c|c|c|}
\hline $\begin{array}{c}\text { Nomes Integrantes } \\
\text { da Diretriz }\end{array}$ & $\begin{array}{l}\text { Participou } \\
\text { de estudos } \\
\text { clínicos elou } \\
\text { experimentais } \\
\text { subvencionados } \\
\text { pela indústria } \\
\text { farmacêutica ou } \\
\text { de equipamentos } \\
\text { relacionados } \\
\text { à diretriz em } \\
\text { questão }\end{array}$ & $\begin{array}{c}\text { Foi } \\
\text { palestrante } \\
\text { em eventos } \\
\text { ou atividades } \\
\text { patrocinadas } \\
\text { pela indústria } \\
\text { relacionados } \\
\text { à diretriz em } \\
\text { questão }\end{array}$ & $\begin{array}{c}\text { Foi (é) } \\
\text { membro do } \\
\text { conselho } \\
\text { consultivo } \\
\text { ou diretivo } \\
\text { da indústria } \\
\text { farmacêutica } \\
\text { ou de } \\
\text { equipa- } \\
\text { mentos }\end{array}$ & $\begin{array}{c}\text { Participou } \\
\text { de comitês } \\
\text { normativos } \\
\text { de estudos } \\
\text { científicos } \\
\text { patroci- } \\
\text { nados pela } \\
\text { indústria }\end{array}$ & $\begin{array}{c}\text { Recebeu auxílio } \\
\text { pessoal ou } \\
\text { institucional da } \\
\text { indústria }\end{array}$ & $\begin{array}{c}\text { Elaborou textos } \\
\text { científicos em } \\
\text { periódicos } \\
\text { patroci- } \\
\text { nados pela } \\
\text { indústria }\end{array}$ & $\begin{array}{c}\text { Tem ações } \\
\text { da } \\
\text { indústria }\end{array}$ \\
\hline $\begin{array}{c}\text { Alexandre Siciliano } \\
\text { Colafranceschi }\end{array}$ & Não & Não & Não & Não & Não & Não & Não \\
\hline Amarino Carvalho de Oliveira Jr. & Não & Não & Não & Não & Não & Não & Não \\
\hline Antonio Carlos Sobral Sousa & Não & Não & Não & Não & Não & Não & Não \\
\hline Arnaldo Rabischoffsky & Não & Não & Não & Não & Não & Não & Não \\
\hline Barbara Maria lanni & Não & Não & Não & Não & Não & Não & Não \\
\hline Carlos Eduardo Rochitte & Não & Não & Não & Não & Não & Não & Não \\
\hline Charles Mady & Não & Não & Não & Não & Não & Não & Não \\
\hline Claudio Tinoco Mesquita & Não & Não & Não & Não & Não & Não & Não \\
\hline Clerio Francisco Azevedo & Não & Não & Não & Não & Não & Não & Não \\
\hline Edimar Alcides Bocchi & Não & Não & Não & Não & Não & Não & Não \\
\hline Eduardo Benchimol Saad & Não & Não & Não & Não & Não & Não & Não \\
\hline Evandro Tinoco Mesquita & $\begin{array}{l}\text { Laboratório Sérgio } \\
\text { Franco }\end{array}$ & $\begin{array}{l}\text { Laboratório } \\
\text { Sérgio Franco }\end{array}$ & Não & Não & Não & Não & Não \\
\hline $\begin{array}{c}\text { Fabiana Goulart Marcondes } \\
\text { Braga }\end{array}$ & Não & Não & Não & Não & Não & Não & Não \\
\hline Fábio Fernandes & Não & Não & Não & Não & Não & Não & Não \\
\hline Felix José Alvarez Ramires & Não & Não & Não & Não & Não & Não & Não \\
\hline Fernando Bacal & Não & Não & Não & Não & Não & Não & Não \\
\hline Gilson Soares Feitosa & Não & Não & Não & Não & Não & Não & Não \\
\hline Harry Correa Filho & Não & Não & Não & Não & Não & Não & Não \\
\hline Hélio Roque Figueira & Não & Não & Não & Não & Abbott/ Medtronic & Abbott & Não \\
\hline Iran Castro & Não & Não & Não & Não & Não & Não & Não \\
\hline João David de Souza Neto & Não & Não & Não & Não & Não & Não & Não \\
\hline Lídia Ana Zytynski Moura & Não & Não & Não & Não & Não & Não & Não \\
\hline $\begin{array}{l}\text { Luiz Antônio de Almeida } \\
\text { Campos }\end{array}$ & Não & Não & Não & Não & Não & Não & Não \\
\hline Marcelo Imbroinise Bittencourt & Não & Não & Não & Não & Não & Não & Não \\
\hline Marcelo Westerlund Montera & Não & Não & Não & Não & Não & Não & Não \\
\hline Márcia de Melo Barbosa & Não & Não & Não & Não & Não & Não & Não \\
\hline $\begin{array}{c}\text { Marcus Vinicius Bolivar } \\
\text { Malachias }\end{array}$ & Não & Não & Não & Não & Não & Não & Não \\
\hline $\begin{array}{c}\text { Maria da Consolação Vieira } \\
\text { Moreira }\end{array}$ & Não & Não & Não & Não & Não & Não & Não \\
\hline Maria de Lourdes Higuchi & Não & Não & Não & Não & Não & Não & Não \\
\hline $\begin{array}{c}\text { Mario Sergio de Carvalho } \\
\text { Bacellar }\end{array}$ & Não & Não & Não & Não & Não & Não & Não \\
\hline Pedro Schwartzmann & Não & Não & Não & Não & Não & Não & Não \\
\hline Ricardo Mourilhe-Rocha & Não & Não & Não & Não & Não & Não & Não \\
\hline Sabrina Bernardez Pereira & Não & Não & Não & Não & Não & Não & Não \\
\hline Sandrigo Mangini & Não & Não & Não & Não & Não & Não & Não \\
\hline Silvia Marinho Martins & Não & Não & Não & Não & Não & Não & Não \\
\hline Solange Bordignon & Não & Não & Não & Não & Não & Não & Não \\
\hline Vitor Agueda Salles & Não & Não & Não & Não & Não & Não & Não \\
\hline
\end{tabular}




\section{Miocardite}

\section{Epidemiologia}

A verdadeira incidência de miocardite é difícil de ser estimada, devido a fatores como: apresentação clínica diversificada, pouca realização biópsia endomiocárdica e falta de critérios histológicos sensíveis e uniformizados.

Os relatos de estudos de autópsias estimam uma incidência entre 0,2 e 12\% dependendo da população estudada $^{1,2}$. O ensaio clínico Myocarditis Treatment Trial relatou uma incidência de 9,6\% de miocardite comprovada por biópsia endomiocárdica (BEM) em pacientes com insuficiência cardíaca $(\mathrm{IC})$ de causa inexplicada ${ }^{3}$. Evidências recentes de alta prevalência de genomas virais em adultos com disfunção ventricular esquerda sugerem que a miocardite é uma das principais determinantes do desenvolvimento da cardiomiopatia dilatada idiopática ${ }^{4}$.

Manifesta maior prevalência no sexo masculino, principalmente adulto jovem, sendo uma das principais causas de morte súbita em pessoas com menos de 40 anos de idade e em crianças ${ }^{5}$. Em crianças que sobrevivem à miocardite notase evolutivamente ao fim de 12 anos, uma maior mortalidade e necessidade de transplante cardíaco.

A miocardite pode estar presente em outras formas de cardiomiopatias, como amiloidose e cardiomiopatia hipertrófica, assim como em pacientes com infarto agudo do miocárdio, o que confere um pior prognóstico a esses pacientes $^{6,7}$.

\section{Etiologia}

A miocardite pode decorrer de diversas causas infecciosas e não infecciosas sendo a miocardite secundária por infecção viral a forma mais prevalente (tabela 1$)^{8}$.

Entre a variedade de doenças infecciosas que podem causar miocardite, as infecções virais são as mais comuns. Os vírus cardiotróficos mais prevalentes são adenovírus, enterovirus, parvovirus-B19, herpes simples, vírus da hepatite C (HCV), citomegalovírus (CMV), e Epstein-Barr (EBV). A prevalência do perfil viral varia conforme o meio estudado. Em nosso meio observa-se prevalência de adenovírus, parvovírus e herpes, à semelhaça do que se encontra na população europeia ${ }^{4,9}$. Já população americana observase o predomínio de enterovírus ${ }^{10}$. Em cerca de 30\% das miocardites virais observamos infecção por mais de um tipo de vírus.

Na infecção por vírus da imunodeficiência humana (HIV/ SIDA) foi observada em estudo de autopsia, a presença de miocardite em mais de $50 \%$ dos pacientes. Em outras formas de infecção não viral, podemos ter o desenvolvimento de miocardite por Clostridium e Corynebacterium diphtheria, Meningococcus, Streptococcus, Listeria e Borrelia burgdorferi, que se manifesta como doença de Lyme ${ }^{11}$.

Na América do Sul e especialmente em algumas regiões do Brasil a miocardite chagásica causada pelo protozoário Trypanosoma cruzi, é a forma mais prevalente de miocardite ou cardiomiopatia dilatada ${ }^{12}$.
Vários fármacos podem causar miocardite de hipersensibilidade hipereosinofílica, ou a agressão tóxica direta do miocárdio, como a ciclofosfamida, a fenitoína, a zidovudina e as anfetaminas. O diagnóstico deve ser suspeitado na presença de eosinofilia no sangue periférico ou infiltrado eosinofílico miocárdico. Também podemos ter o desenvolvimento de miocardite eosinofílica linfocítica secundária a vacinação ${ }^{13-15}$

Doenças sistêmicas autoimunes como a síndrome de Churg-Strauss ${ }^{16}$, e a síndrome hipereosinofílica estão associadas à miocardite eosinofílica ${ }^{17}$. A miocardite de células gigantes e a sarcoidose, embora raras, quando diagnosticadas precocemente podem ter o prognóstico alterado através de tratamento adequado ${ }^{18,19}$.

Dentre as colagenoses temos a artrite reumatoide, a dermatomiosite e o lúpus eritematoso sistêmico como as de maior prevalência na agressão inflamatória miocárdica.

A cardiomiopatia periparto apresenta como possíveis fatores etiológicos: agressão viral, autoimunidade, distúrbio nutricional e origem familiar. A prevalência de miocardite é variável observada em até $62 \%$ dos pacientes submetidos a biópsia endomiocárdica. A provável infecção viral e autoimune se deve à maior suscetibilidade às infecções virais na fase gestacional e pela possibilidade de ativação imunológica pelas células fetais na fase pós-parto ${ }^{20,21}$.

\section{Tabela 1 - Etiologia das miocardites.}

\begin{tabular}{|c|c|}
\hline \multicolumn{2}{|r|}{ Infecciosa } \\
\hline Vírus RNA & $\begin{array}{l}\text { Picornaviruses (coxsackie A + B, echovirus, poliovirus, } \\
\text { hepatitis virus), orthomyxovirus (influenza), paramyxoviruses } \\
\text { (respiratory syncitial virus, mumps), togaviruses (rubella), } \\
\text { flaviviruses (dengue fever, yellow fever) }\end{array}$ \\
\hline Vírus DNA & $\begin{array}{l}\text { Adenovirus (A 1, } 2,3 \text {, e 5), erythrovirus [1 (B19V) and 2], } \\
\text { herpesviruses (human herpes virus } 6 \mathrm{~A} / \mathrm{B} \text {, cytomegalievirus, } \\
\text { Epstein-Barr virus, varicella-zoster virus), retrovirus (HIV) }\end{array}$ \\
\hline Bactérias & $\begin{array}{l}\text { Chlamydia (C. pneumonialpsittacosis) haemophilus } \\
\text { influence, legionella, pneumophilia, brucella clostridium, } \\
\text { francisella tularensis, neisseria meningitis, mycobacterium } \\
\text { (tuberculosis), salmonella, staphylococcus, streptococcus A, } \\
\text { S. pneumonia, tularemia, tetanus, syphilis, Vibrio cholera }\end{array}$ \\
\hline Espiroquetas & Borrelia recurrentis, leptospira, Treponema pallidum \\
\hline Reckettsia & Coxiella burnetii, R. rickettsii/prowazekii \\
\hline Fungos & $\begin{array}{c}\text { Actinomyces, aspergillus, candida, cryptococcus, } \\
\text { histoplasma, nocardia }\end{array}$ \\
\hline Protozoários & $\begin{array}{c}\text { Entamoeba histolytica, leishmania, Plasmodium } \\
\text { falciparum, Trypanosoma cruzi, Trypanosoma brucei, } \\
\text { Toxoplasma gondii }\end{array}$ \\
\hline Helmintos & $\begin{array}{l}\text { Ascaris, Echinococcus granulosus, Schistosoma, } \\
\text { Trichinella spiralis, Wuchereria bancrofti }\end{array}$ \\
\hline \multicolumn{2}{|r|}{ Não Infecciosa } \\
\hline $\begin{array}{l}\text { Doenças } \\
\text { autoimunes }\end{array}$ & $\begin{array}{l}\text { Dematomyositis, inflammatory bowel disease, rheumatoid } \\
\text { arthritis, Sjogren's syndrome, systemic lupus erythematodes, } \\
\text { Wegener's granulomatosis, giant cell myocarditis }\end{array}$ \\
\hline Fármacos & $\begin{array}{l}\text { Aminofilina, anfetaminas, antracíclicos, catecolaminas, } \\
\text { cloranfenicol, ciclofosfamida, doxorubicina, 5-fluoruracil, } \\
\text { fenitoína, mesilato, metilsergide, trastuzumab, zidovudine }\end{array}$ \\
\hline
\end{tabular}




\section{Diretrizes}

\begin{tabular}{|c|c|}
\hline \multicolumn{2}{|r|}{ Não Infecciosa } \\
\hline $\begin{array}{c}\text { Reações de } \\
\text { hipersensibilidade } \\
\text { (fármacos): }\end{array}$ & $\begin{array}{l}\text { Azitromycin, benzodiazepines, clozapine, } \\
\text { cephalosporins, dapsone, dobutamin, lithium, diuretics, } \\
\text { thiazide, methyldopa, mexiletine, Streptomycin, } \\
\text { sulfonamides, non-steroidal anti-inflammational drugs, } \\
\text { tetanus toxoid, tetracycline, tricyclic antidepressivo }\end{array}$ \\
\hline $\begin{array}{c}\text { Reações de } \\
\text { hipersensibilidade }\end{array}$ & Abelha, vespa, aranha viúva-negra, escorpião, cobra. \\
\hline $\begin{array}{l}\text { Doenças } \\
\text { sistêmicas }\end{array}$ & $\begin{array}{l}\text { Síndrome de Churg-Strauss, doenças do colágeno, } \\
\text { sarcoidose, doença de Kawasaki, esclerodermia. }\end{array}$ \\
\hline Outros & $\begin{array}{l}\text { Infarto agudo do miocárdio, hipotermia, rejeição do } \\
\text { transplante, radiação }\end{array}$ \\
\hline
\end{tabular}

\section{Fisiopatologia}

A miocardite viral pode ser dividida em fase aguda, subaguda e crônica. O conhecimento dessa evolução temporal e fisiopatológica se faz importante na definição diagnóstica e nas possibilidades terapêuticas ${ }^{22}$.

A fase aguda caracteriza-se pela presença de viremia. Ocorre perda de miócitos por necrose graças a ação direta do vírus, efeitos citotóxicos de mediadores inflamatórios e produtos do estresse oxidativo associado a disfunção endotelial e isquemia ${ }^{23}$. A ação direta ocorre pela entrada do vírus na célula, por meio de receptores de membrana como o CAR (coxsackie-adenovirus receptor) e lesão citoplasmática e nuclear ${ }^{24}$. Segue-se à agressão viral, um complexo mecanismo de ativação do sistema imune com importante infiltrado inflamatório com células natural killer e macrófagos. A produção de citocinas (interleucina 1 e 2, interferon $\gamma$ e fator de necrose tumoral $)^{25}$ faz parte dessa resposta inflamatória, sendo um mecanismo de defesa, que pode danificar os miócitos na dependência do tempo e dos níveis de exposição dessas células. Anticorpos neutralizantes não são observados até o $4^{\circ}$ dia, quando os títulos virais são muito elevados. Esses anticorpos são responsáveis pela tentativa de clearance viral seu pico é alcançado no 14음 dia, e estão relacionados com a eliminação do vírus no coração (10음ia).

A fase subaguda inicia-se a partir do $4^{\circ}$ dia da inoculação e estende-se até o $14^{\circ}$ dia. O infiltrado de linfócitos T segue na invasão do miocárdio, atingindo o seu pico em 7 a 14 dias após a inoculação viral. Nessa fase ocorre maior dano celular miocárdico. Existe também infiltração de linfócitos B, sendo que a proporção aumenta gradativamente no decorrer do $1^{\circ}$ ao $3^{\circ}$ mês ${ }^{26}$. A resposta imune humoral tem importante papel na lesão e disfunção miocárdica. A lesão direta ou indireta dos miócitos libera a miosina na circulação, e a presença dessa proteína promove a liberação de anticorpos contra a cadeia pesada da miosina e estimula os linfócitos CD4, os quais podem perpetuar e amplificar a lesão das células cardíacas. Essa amplificação estimulada pelos linfócitos T CD4 se dá por estímulo aos linfócitos B na produção de anticorpos antimiosina e por estimular a presença citotóxica de linfócitos T CD8. A reação cruzada de anticorpos entre antígenos virais e células miocárdicas também proporciona a lesão dos miócitos. O soro de pacientes com miocardite apresenta padrões imunohistoquímicos, que podem reagir com diferentes proteínas da membrana ou do citoplasma do miócito cardíaco ${ }^{27}$.
A terceira fase inicia-se no $15^{\circ}$ dia e segue até o $90^{\circ}$ dia após a inoculação viral, e caracteriza-se pela deposição intensa de colágeno no interstício miocárdico com fibrose miocárdica evoluindo para dilatação, disfunção e insuficiência cardíaca $^{28,29}$.

No caso da miocardite bacteriana, além da agressão bacteriana direta aos miócitos, a produção importante de toxinas (com níveis de toxicidade variáveis dependendo do agente etiológico) e a resposta inflamatória intensa com a produção de níveis elevados de citocinas são responsáveis pelo dano celular, com predomínio de infiltrado de macrófagos e células natural killer.

$\mathrm{Na}$ miocardite induzida por drogas, a resposta de sensibilidade pode variar de horas a meses. Parte da justificativa da hipersensibilidade se dá em resposta a componentes quimicamente reativos que se ligam a proteínas promovendo modificações estruturais. Essas partículas são fagocitadas pelas células de defesa, por vezes macrófagos, os quais as apresentam na superfície dessas células aos linfócitos T. Como uma resposta de hipersensibilidade retardada, são liberadas citocinas como interleucina 5, estimulante de eosinófilos. Esse acúmulo de interleucina 5 promove um grande infiltrado eosinofílico com aumento da resposta de hipersensibilidade e maior lesão miocárdica. A predisposição genética parece favorecer esse padrão de resposta.

A síndrome hipereosinofílica pode ocorrer em associação a diversas doenças com manifestação sistêmica, como síndrome de Churg-Strauss, câncer, infecções parasitárias e helmínticas, ou estar relacionada a vacinações. Estas podem promover uma resposta inflamatória intensa no miocárdio, levando a lesão celular com disfunção e IC $\mathrm{IC}^{30-32}$.

Do ponto de vista fisiopatológico, assim como em outros órgãos, ocorre um intenso infiltrado eosinofílico (principalmente CD69) no miocárdio, infiltrado este que promove a liberação de mediadores altamente agressivos ao miócito, levando a necrose e perda da estrutura miocárdica. Entre os fatores agressores estão a neurotoxina, derivada dos eosinófilos, a proteína catiônica do eosinófilo e a protease eosinofílica. Além desses fatores, a produção de citocinas inflamatórias como IL 1, TNF-alfa, IL 6, IL 8, IL3, IL5 e proteínas inflamatórias do macrófago promove a lesão e perda de miócitos, com evolução para disfunção miocárdica ${ }^{33}$.

A miocardite de células gigantes é uma forma autoimune de agressão miocárdica e caracteriza-se histologicamente por um infiltrado de células gigantes multinucleadas, além de infiltrado inflamatório de células T, eosinófilos e histiócitos. Entretanto, por vezes, um granuloma bem definido não é observado. A presença marcante de células CD8 (citotóxicas) promove intensa lesão miocítica. Essa patologia encontrase, em até $20 \%$ dos casos, associada a doenças autoimunes como tireoidite de Hashimoto, artrite reumatoide, miastenia gravis, arterite de Takayasu, entre outras. A grande liberação de citocinas inflamatórias e mediadores do estresse oxidativo leva a uma intensa agressão às células miocíticas com perda de miócitos e reposição por fibrose. Essa intensa agressão promove uma evolução acelerada, perda rápida da função ventricular e evolução clínica desfavoráve ${ }^{34}$. 
A sarcoidose é uma doença multissistêmica de etiologia desconhecida, caracterizada pelo acúmulo de linfócitos T, fagócitos mononucleares e granulomas não caseosos nos tecidos envolvidos ${ }^{35,36}$. Os pulmões são afetados em aproximadamente $90 \%$ dos pacientes, e a presença de doença pulmonar contribui de forma independente para a morbimortalidade associada a essa doença.

\section{Diagnóstico}

A avaliação diagnóstica da miocardite se faz inicialmente através da suspeita clínica, juntamente com métodos diagnósticos não invasivos. A confirmação diagnóstica só é possível através da análise histológica obtida pela biópsia endomiocárdica do ventrículo direito. Na prática clínica a maioria dos diagnósticos de miocardite são de suspeição diagnóstica, pois somente a minoria dos pacientes com suspeita de miocardite são submetidos a investigação por biópsia endomiocárdica para confirmação da agressão inflamatória (Figura 1).

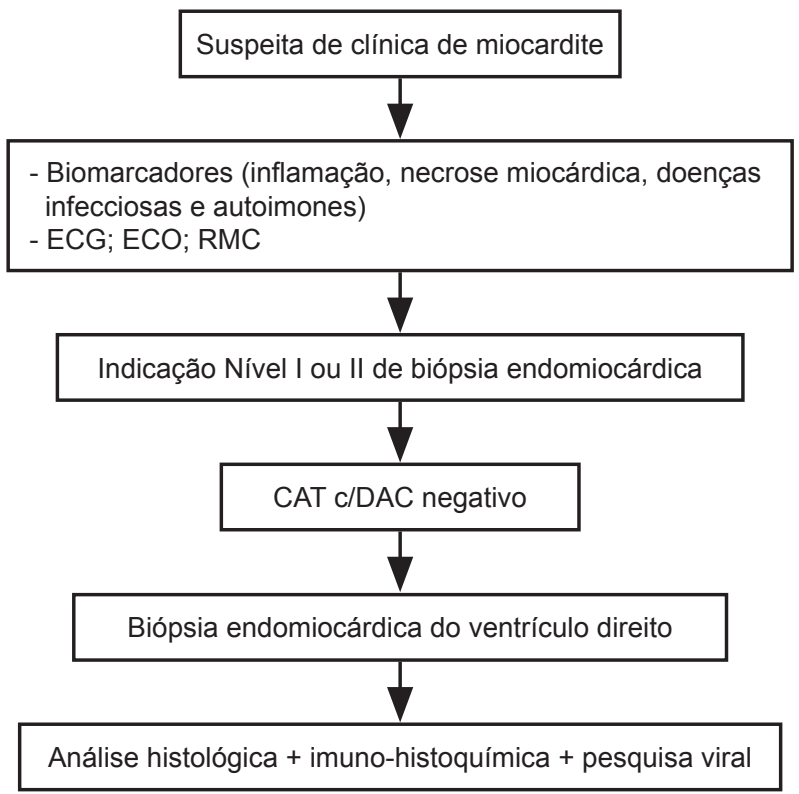

ECG: Eletrocardiograma; ECO: Ecocardiograma; RMC: Ressonância Magnética Cardíaca; CAT: Cateterismo Cardíaco; DAC: Doença Arteria Coronariana.

Figura 1 - Fluxograma de avaliação diagnóstica da miocardite.

\subsection{Clínico}

As manifestações clínicas da doença são bastante variáveis, podendo abranger formas sub-clínicas, como dilatação e disfunção ventricular assintomática, ou mesmo manifestações clínicas agudas de insuficiência cardíaca descompensada, fulminante com quadro de choque cardiogênico, dor precordial, mimetizando doença coronariana, palpitações, síncope, ou lipotimia, e morte súbita ${ }^{22,37,38}$.
A despeito do fato de que a maioria das formas de miocardite tem sua gênese em um quadro viral, a presença de infecção respiratória, gastrointestinal ou sistêmica de infecção viral é observada em somente cerca de $30 \%$ dos pacientes nas formas agudas de manifestação ${ }^{39}$.

Nas formas agudas com dor torácica, pode se manifestar de modo similar à dor anginosa, com achados semelhantes aos de uma síndrome coronariana aguda, incluindo alterações no eletrocardiograma (ECG) e elevação dos marcadores de necrose miocárdica, ou com características da pericardite, no caso do envolvimento epimiocárdico. Outras formas de apresentação clínica seriam como um quadro de insuficiência cardíaca aguda, arritmias ventriculares e atriais frequentes, choque cardiogênico e morte ${ }^{13,40}$.

Em crianças e neonatos, a miocardite usualmente apresenta-se como insuficiência cardíaca aguda, por vezes fulminante ${ }^{41}$ e com menor frequência como cardiomiopatia dilatada oligossintomática.

Nas formas subaguda e crônica, frequentemente a miocardite se manifesta primeiro como CMD de início recente ou de tempo indeterminado, em paciente assintomático ou com sintomas de insuficiência cardíaca.

Mais raramente, a miocardite pode se manifestar com alterações eletrocardiográficas apontando distúrbios de condução atrioventricular de grau variável, associados ou não a bloqueio de ramo. Em formas avançadas, os pacientes apresentam quadro de baixo débito em decorrência de bloqueio atrioventricular total com ritmo de escape ${ }^{42}$.

Outros sintomas apontam para formas mais específicas de miocardite, por exemplo: (1) rash, febre, eosinofilia periférica sugerem miocardite por hipersensibilidade; (2) cardiomiopatia dilatada associada com timoma, distúrbios autoimunes, taquicardia ventricular ou bloqueios avançados sugerem miocardite de células gigantes; (3) arritmias ventriculares e bloqueios avançados também podem estar presentes na sarcoidose $^{43}$.

\subsection{Avaliação laboratorial}

\subsubsection{Marcadores laboratoriais de agressão inflamatória}

Marcadores séricos inespecíficos de inflamação, como velocidade de hemossedimentação, proteína $C$ reativa e leucometria, podem estar elevados ou inalterados. Eles podem espelhar a inflamação miocárdica ou pericárdica, ou representarem a manifestação de doença sistêmica autoimune ou de hipersensibilidade. A detecção da elevação dos biomarcadores de necrose miocárdica na miocardite aguda depende da fase evolutiva e da extensão da agressão inflamatória no momento da investigação diagnóstica. De modo diferente do que ocorre nas síndromes coronarianas em que existe uma curva de elevação e redução habitual, os marcadores de necrose miocárdica na miocardite se mantêm em um platô por maior tempo. A elevação de troponinas ( I ou T) é mais comum que da CK-MB, e níveis elevados conferem pior prognóstico (tabela 2) $25-27,33,34$. 


\section{Diretrizes}

\subsubsection{Marcadores laboratoriais de pesquisa etiopatogênica}

A pesquisa do fator causal da miocardite através de exames complementares estará na dependência da suspeição clínica. Usualmente todos os pacientes devem ser investigados para doenças sistêmicas inflamatórias autoimunes, como lúpus, artrite reumatoide, sarcoidose, Churg-Strauss, doença celíaca $^{10}$. A pesquisa de sorologias virais possui baixa sensibilidade e especificidade, apresentando uma correlação de somente $4 \%$ da sorologia com a infecção viral miocárdica ${ }^{44}$. Esse dado demonstra que a sorologia viral não deve ser utilizada de forma rotineira para a investigação diagnóstica da miocardite (tabela 2). No Brasil, a doença de Chagas, em razão de sua alta prevalência deve ser investigada de forma rotineira em todos os pacientes de áreas endêmicas.

Tabela 2 - Recomendação de exames laboratoriais na miocardite.

\begin{tabular}{ccc}
\hline $\begin{array}{c}\text { Classe de } \\
\text { recomendação }\end{array}$ & Indicações & $\begin{array}{c}\text { Nível de } \\
\text { evidência }\end{array}$ \\
\hline Classe I & $\begin{array}{c}\text { Investigação de doenças inflamatórias } \\
\text { sistêmicas na miocardite aguda }\end{array}$ & $\mathrm{C}$ \\
\hline Classe Ila & $\begin{array}{c}\text { Troponina como diagnóstico e } \\
\text { prognóstico na miocardite aguda }\end{array}$ & $\mathrm{B}$ \\
\hline Classe Ila & $\begin{array}{c}\text { Marcadores inflamatórios inespecíficos } \\
\text { (VHS, proteína C reativa, leucometria) } \\
\text { para diagnóstico na miocardite aguda }\end{array}$ & $\mathrm{C}$ \\
\hline Classe Ilb & Sorologias virais & $\mathrm{B}$ \\
\hline
\end{tabular}

\subsection{Eletrocardiograma}

As alterações de eletrocardiograma na miocardite vão depender da fase de evolutiva em que se encontra a agressão inflamatória miocárdica. Usualmente esse exame possui uma sensibilidade diagnóstica de $47 \%{ }^{45}$.

$\mathrm{Na}$ fase aguda, as alterações mais comuns são os distúrbios de repolarização e bloqueios atrioventriculares, assim como padrão sugestivo de isquemia coronariana com infra ou supradesnível do segmento ST de região cardíaca específica ou difusa, sendo que a presença de onda $Q$ indica pior prognóstico. A presença de arritmias supraventriculares ou ventriculares é frequente ${ }^{27,33}$. Nas fases subaguda ou "crônica", predominam os sinais eletrocardiográficos de remodelamento de câmaras, como sobrecarga ventricular e presença de bloqueio de ramo esquerdo, ambos relacionados a pior prognóstico ${ }^{46}$.

Nos quadros de acometimento do pericárdio em associação ao miocárdio (perimiocardite), é comum o padrão clássico eletrocardiográfico de pericardite com supradesnível do segmento ST difuso e infra do segmento PR é comum ${ }^{47}$.

A recomendação para a realização de eletrocardiograma na miocardite encontra-se na tabela 3 .

Tabela 3 - Recomendações de Eletrocardiograma para avaliação de miocardite.

\begin{tabular}{ccc}
\hline $\begin{array}{c}\text { Classe de } \\
\text { recomendação }\end{array}$ & Indicação & $\begin{array}{c}\text { Nível de } \\
\text { evidência }\end{array}$ \\
\hline Classe I & ECG na suspeita de miocardite & $\mathrm{C}$ \\
\hline
\end{tabular}

\subsection{Ecocardiograma}

Os achados ecocardiográficos na miocardite são inespecíficos. As alterações ecocardiográficas espelham a agressão inflamatória miocárdica e as consequências desta sobre a função e remodelagem ventricular, podendo ser encontrados trombos intraventriculares ou atriais ${ }^{48,49}$. As alterações na contração ventricular podem ser difusas ou segmentares, indistinguíveis das alterações isquêmicas ${ }^{9,50}$.

A presença de disfunção ventricular direita é incomum, e quando ocorre indica pior prognóstico ${ }^{51}$. Na miocardite fulminante, usualmente encontramos importante disfunção sistólica com diâmetros cavitários normais, por vezes associada a aumento da espessura da parede septal, indicando edema miocárdico ${ }^{49,52}$. A presença de derrame pericárdico na ausência de IC congestiva sugere envolvimento inflamatório do pericárdio com miopericardite.

O ecocardiograma tem importante papel no diagnóstico diferencial da miocardite com outras patologias que tenham a mesma forma clínica de apresentação - como doenças valvulares agudas, cardiomiopatia inflamatória de takotsubo e infarto agudo do miocárdio - além de servir como um guia durante a realização da biópsia endomiocárdica (tabela 4).

Tabela 4 - Recomendações de ecocardiograma para avaliação de miocardite.

\begin{tabular}{ccc}
\hline $\begin{array}{c}\text { Classe de } \\
\text { recomendação }\end{array}$ & Indicações & $\begin{array}{c}\text { Nível de } \\
\text { evidência }\end{array}$ \\
\hline Classe I & $\begin{array}{c}\text { Ecocardiograma para avaliação } \\
\text { funcional }\end{array}$ & $\mathrm{B}$ \\
\hline Classe lla & Ecocardiograma no auxílio a BEM & $\mathrm{C}$ \\
\hline
\end{tabular}

\subsection{Ressonância magnética cardíaca}

$\mathrm{Na}$ avaliação dos pacientes com miocardite, a ressonância magnética cardíaca (RMC) permite identificar tanto a injúria miocárdica inflamatória das fases aguda e subaguda quanto as lesões cicatriciais frequentemente presentes na fase crônica da doença. As três principais técnicas de RMC utilizadas na caracterização da injúria miocárdica dos pacientes com miocardite são as sequências ponderadas em T2 (T2 imaging), o realce miocárdico global precoce e a técnica do realce tardio ${ }^{53}$.

As imagens adquiridas pelas sequências ponderadas em T2 permitem avaliar o edema miocárdico secundário ao processo inflamatório nos pacientes com miocardite aguda, e podem ser tanto do tipo regional quanto global.

Na técnica do realce global precoce, as imagens adquiridas nos primeiros minutos após a administração do gadolínio representam as áreas mais acometidas pela injúria inflamatória ${ }^{54,55}$. A avaliação consiste na medida de intensidade de sinal pré e pós a injeção de contraste baseado em gadolínio e na comparação com a variação da intensidade do músculo esquelético dentro do campo de visão (exemplo: músculo peitoral). Relações maiores que quatro vezes entre miocárdio e músculo esquelético indicam hiperemia e extravasamento capilar causados pela inflamação.

A técnica do realce tardio, por sua vez, permite avaliar as regiões de injúria miocárdica irreversível, o que permite identificar as regiões de necrose, no caso das miocardites agudas ou subagudas, 
e as regiões de fibrose, no caso das miocardites crônicas ${ }^{56-58}$. O padrão de distribuição do realce tardio na miocardite é muito diferente daquele observado nos casos de infarto do miocárdio. É frequentemente mesoepicárdico poupando o endocárdio, mas também pode apresentar distribuição epicárdica e transmural. As regiões de realce costumam ser multifocais, heterogêneas e esparsas, não respeitando os territórios coronarianos. Mas esse padrão de distribuição não tem se mostrado obrigatório, de modo que se pode, por vezes, observar distribuição semelhante à doença coronariana.

Diversos estudos demonstraram que, embora cada uma das técnicas apresente boa acurácia diagnóstica quando utilizada isoladamente, os melhores resultados são obtidos através da combinação dos três critérios diagnósticos ${ }^{48}$ à presença de pelo menos um dos critérios descritos acima (qualquer um dos três), a RMC mostra sensibilidade de $88 \%$, especificidade de $48 \%$, valor preditivo positivo (VPP) de $68 \%$, valor preditivo negativo (VPN) de $68 \%$ e acurácia de $70 \%$. Na presença de dois dos critérios (quaisquer dois dos três), a RMC registra sensibilidade de 67\%, especificidade de 91\%, valor preditivo positivo (VPP) de 91\%, valor preditivo negativo (VPN) de $69 \%$ e acurácia de $78 \%{ }^{9}$. Os resultados de acurácia na miocardite aguda são superiores aos do que nos casos de suspeita de miocardite subaguda ou crônica.

A RMC está indicada na avaliação diagnóstica dos pacientes com suspeita de miocardite aguda e crônica e naqueles portadores de disfunção ventricular de início recente com suspeita de miocardite prévia, independentemente da forma de manifestação. Entretanto apresenta especial valor naqueles com elevação dos marcadores de necrose miocárdica e coronárias normais na avaliação angiográfica (apresentação aguda tipo infarto). A RMC deve ser realizada o mais precocemente a partir da suspeita clínica. Exames subsequentes de reavaliação devem ser feitos com quatro e doze semanas após o episódio agudo, com o objetivo de avaliar a evolução do processo inflamatório, quando positivo o exame, e a função de remodelagem. Devido a questões logísticas inerentes ao método, a RMC não está indicada na avaliação dos pacientes portadores de miocardite fulminante com instabilidade hemodinâmica (tabela 5).

A presença de realce tardio positivo revela correlação com pior prognóstico evolutivo a longo prazo em pacientes com miocardite viral comprovada por biópsia endomiocárdica, sendo maiores a mortalidade total e a mortalidade cardíaca, independentemente dos sintomas clínicos e da função ventricular. A ausência de realce tardio demonstrou estar relacionada a um baixo risco de morte súbita, mesmo na presença de disfunção e dilatação ventricular ${ }^{59}$.

Tabela 5 - Recomendações de RMC na avaliação de miocardite.

\begin{tabular}{ccc}
\hline $\begin{array}{c}\text { Classe de } \\
\text { recomendação }\end{array}$ & Indicações & $\begin{array}{c}\text { Nível de } \\
\text { evidência }\end{array}$ \\
\hline Classe I & $\begin{array}{c}\text { RMC na avaliação da função, geometria } \\
\text { e morfologia ventricular na suspeita de } \\
\text { miocardite aguda, sub-aguda e crônica. }\end{array}$ & B \\
\hline Classe lla & $\begin{array}{c}\text { RMC na investigação diagnóstica } \\
\text { de miocardite aguda ,crônica e/ou } \\
\text { suspeita de miocardite prévia }\end{array}$ & B \\
\hline Classe Ila & $\begin{array}{c}\text { RMC no acompanhamento de 4 semanas } \\
\text { a 12 semanas do episódio agudo }\end{array}$ & C \\
\hline Classe III & $\begin{array}{c}\text { RMC na miocardite fulminante com } \\
\text { instabilidade hemodinâmica }\end{array}$ & B \\
\hline
\end{tabular}

\subsection{Angiotomografia computadorizada}

A tomografia computadorizada cardíaca (TCC) é mais rápida e mais acessível que a RMC, no diagnóstico diferencial de dor torácica, mas tem a desvantagem de usar contraste iodado e radiação ionizante60. Pode fornecer imagens de coronárias normais (quando trigada pelo ECG) ${ }^{61}$, excluindo a isquemia e o infarto miocárdico.

Adicionalmente, a angiotomografia coronariana pode ser utilizada no diagnóstico diferencial com síndrome coronariana aguda, para excluir a presença de DAC significativa nos pacientes com quadro tipo infarto (dor precordial, elevação dos marcadores de necrose miocárdica e alterações eletrocardiográficas) (tabela 6).

Tabela 6 - Recomendações de angiotomografia de coronárias na avaliação de miocardite.

\begin{tabular}{ccc}
\hline $\begin{array}{c}\text { Classe de } \\
\text { recomendação }\end{array}$ & Indicação & $\begin{array}{c}\text { Nível de } \\
\text { evidência }\end{array}$ \\
\hline Classe lla & $\begin{array}{c}\text { AngioTC de coronárias para exclusão } \\
\text { de coronariopatia obstrutiva grave na } \\
\text { investigação de miocardite }\end{array}$ & C \\
\hline
\end{tabular}

\subsection{Medicina nuclear}

Os exames de medicina nuclear têm sido aplicados há mais de três décadas na avaliação de pacientes com suspeita de miocardite ${ }^{62}$. Suas principais aplicações estão relacionadas à avaliação da função ventricular esquerda, avaliação da presença de inflamação cardíaca, identificação de subtipos de miocardites e monitoração da resposta terapêutica.

Na avaliação da presença de inflamação cardíaca a presença de inflamação miocárdica pode ser detectada por diversas técnicas radionuclídicas ${ }^{63,64}$. A mais estudada na literatura é a cintilografia com 67-Gálio, que apresenta sensibilidade de $50 \%$ no diagnóstico da miocardite, sendo que sua melhor utilização diagnóstica se dá nos primeiros três meses de apresentação clínica ${ }^{65}$. Em alguns determinados tipos de miocardite como na sarcoidose, proporciona maior acurácia.

Em casos de gálio positivo associado a biópsia endomiocárdica positiva para inflamação, podemos utilizar a evolução do marcador em exames subseqüentes, para o acompanhamento da atividade inflamatória e resposta terapêutica (tabela 7). O Indio111 marcado com anticorpos monoclonais mostrou, em alguns estudos, ser preditor de miocardite na biópsia miocárdica.

Tabela 7 - Recomendações de cintilografia miocárdica na avaliação de miocardite.

\begin{tabular}{ccc}
\hline $\begin{array}{c}\text { Classe de } \\
\text { recomendação }\end{array}$ & Indicação & $\begin{array}{c}\text { Nível de } \\
\text { evidência }\end{array}$ \\
\hline Classe Ilb & $\begin{array}{c}\text { Cintilografia com Gálio na pesquisa de } \\
\text { miocardite }\end{array}$ & B \\
\hline
\end{tabular}

\subsection{Biópsia endomiocárdica}

A biópsia endomiocárdica (BEM) é o método "padrãoouro" para o diagnóstico da miocardite, pesquisa de persistência viral cardíaca, assim como de outras doenças 
cardiovasculares não inflamatórias. A BEM tem como objetivos estabelecer o diagnóstico de inflamação miocárdica com ou sem persistência viral para definir a necessidade e o tipo de terapêutica a ser adotada ${ }^{66}$.

Nas situações clínicas onde há insuficiência cardíaca de início recente (menos de 2 semanas), com instabilidade hemodinâmica, sem resposta ao tratamento usual e/ou presença de arritmias ventriculares ou bloqueios cardíacos de alto grau, a BEM desempenha importante papel na investigação do fator causal, com impacto na terapêutica. Ela altera favoravelmente o prognóstico ao determinar o tratamento imunossupressor em cenários clínicos como o da miocardite de células gigantes, eosinofílica necrotizante e da sarcoidose ${ }^{67-69}$.

A BEM na cardiomiopatia dilatada crônica de provável etiologia viral sintomática tem sido foco de estudos, uma vez que já foi demonstrado que a terapia antiviral ou imunomoduladora ocasiona melhora da fração de ejeção em pacientes com IC sintomática após seis meses de terapia otimizada ${ }^{70}$.

A miocardite também pode ser causada por certas terapias farmacológicas, e a BEM tem papel essencial naqueles casos de dúvida diagnóstica e rápida progressão da doença, com suspeita de reação alérgica e eosinofilia auxilia na busca do diagnóstico diferencial com outras condições. Dada a sua natureza invasiva, a BEM para pacientes tratados com agentes quimioterápicos é reservada aos casos de evolução desfavorável associada a dúvida quanto à causa da disfunção cardíaca ${ }^{71}$.

São poucos os estudos, na literatura, sobre a indicação de BEM nos casos de arritmia ventricular de causa indefinida. A incidência do diagnóstico histológico de miocardite nesses eventos varia muito entre os estudos. A detecção de miocardite ativa em um paciente com arritmia ventricular maligna pode, teoricamente, levar à decisão de adiar a implantação do cardiodesfibrilador implantável até a redução da atividade inflamatória, mas esse tipo de abordagem ainda permanece controverso ${ }^{72}$.

As indicações de BEM na miocardite encontram-se na tabela 8 .

Tabela 8 - Indicações de biópsia endomiocárdica.

\begin{tabular}{ccc}
\hline $\begin{array}{c}\text { Classe de } \\
\text { recomendação }\end{array}$ & Indicações & $\begin{array}{c}\text { Nível de } \\
\text { evidência }\end{array}$ \\
\hline Classe I & $\begin{array}{c}\text { IC de início recente (<2 semanas), sem } \\
\text { causa definida, não responsiva ao tratamento } \\
\text { usual e com deterioação hemodinâmica }\end{array}$ & B \\
\hline Classe I & $\begin{array}{c}\text { IC de início recente (2 semanas a 3 meses), } \\
\text { sem causa definida e associada a arritmias } \\
\text { ventriculares ou bloqueios atrioventriculares } \\
\text { de segundo ou terceiro graus. }\end{array}$ & B \\
\hline Classe Ila & $\begin{array}{c}\text { IC com início (> 3 meses e < 12 meses), } \\
\text { sem causa definida e sem resposta à } \\
\text { terapia-padrão otimizada. }\end{array}$ & C \\
\hline Classe Ila & $\begin{array}{c}\text { IC decorrente de cardiomiopatia dilatada } \\
\text { de qualquer duração, com suspeita de } \\
\text { reação alérgica e/ou eosinofilia. }\end{array}$ & C \\
\hline Classe IIb & $\begin{array}{c}\text { Arritmias ventriculares frequentes na } \\
\text { presença ou não de sintomas, } \\
\text { sem causa definida. }\end{array}$ & C \\
\hline
\end{tabular}

\subsubsection{Técnica}

O procedimento deve ser realizado no laboratório de hemodinâmica, por hemodinamicista com experiência na realização desse procedimento. A anestesia é local com sedação consciente, se necessário, sempre sob a supervisão do anestesiologista.

A biópsia endomiocárdica pode ser realizada de forma segura, guiada por fluoroscopia direta, e deve ter auxílio do ecocardiograma na sua realização ${ }^{73,74}$ que servirá guia para o posicionamento correto do biótomo para que se evite puncionar a parede livre do ventrículo direito (VD) ${ }^{75}$.

$A$ realização de RMC prévia à BEM pode ser de grande utilidade na identificação das lesões focais no VD ou VE, direcionando a coleta do material ${ }^{76}$. Não existem estudos comparativos para que se recomende a biópsia endocárdica do VD ou do VE, entretanto a realização da biópsia endomiocárdica do VE deve ser realizada somente nos casos em que o processo esteja definitivamente limitado a esta cavidade, o que pode ser definido, em alguns casos, pela RMC.

As amostras devem ser obtidas no ventrículo direito, especialmente a porção distal do septo interventricular e a área trabeculada apical, evitando-se a parede livre do VD. O número de amostras dependerá da pesquisa a ser realizada ${ }^{77}$. No caso de investigação de miocardite viral, devem ser 10 amostras (6 para pesquisa viral, 2 para hematoxilina-eosina e 2 para imunohistoquímica). No caso de investigação de doenças infiltrativas ou de depósito, 6 fragmentos (2 para hematoxilina-eosina, 2 para imuno-histoquímica e 2 para microscopia eletrônica). As amostras para HE e imunohistoquímica devem ser colocadas em frasco de formalina tamponada a 10\% e não devem ser refrigeradas. As amostras para pesquisa viral devem ser colocadas em microtubos tipo Eppendorf ${ }^{\circledR}$ (sem soluções de transporte), e estes em recipientes com gelo seco, e rapidamente transferidas para refrigeradores -70 graus para armazenamento. As amostras para microscopia eletrônica devem ser acondicionadas em tubos Eppendorf ${ }^{\circledR}$ Com solução oct.

\subsubsection{Complicações}

As complicações da biópsia endomiocárdica felizmente são raras, da ordem de 1,7\% em cerca de 2.400 pacientes $^{78} \mathrm{e}$ menos de $1 \%$ em outra série de mais de 4000 pacientes $^{79}$. A utilização do ecocardiograma associado à fluoroscopia reduz de forma significativa a possibilidade de punção inadvertida que possa ocasionar perfuração miocárdica ou lesão de coronária.

As complicações descritas são: reação vaso-vagal, bloqueios AV de graus variados, perfuração de parede livre de VD, pneumotórax, perfuração do septo interventricular, hematoma de sítio de punção, fístulas intracardíacas, hematoma retroperitoneal (acesso femoral), derrame pericárdico, deslocamento de trombos, tamponamento cardíaco, ruptura de cordoalhas tricúspides, arritmias ventriculares.

\subsection{Patologia}

\subsubsection{Análise patológica}

O clássico critério de Dallas para miocardite requer células inflamatórias e necrose de miócitos à BEM, sendo a ausência de necrose caracterizada como miocardite borderline. Esse 
critério é bastante criticado pela falta de correlação com a evolução clínica, a presença de vírus e a variabilidade entre patologistas ${ }^{80}$. Recentemente tem-se proposto que o diagnóstico histológico de inflamação se faça através da contagem de linfócitos, macrófagos e expressão HLA-DR pela técnica de imuno-histoquímica ${ }^{81}$.

Miocardite fulminante - A miocardite fulminante tem como causa mais comum uma miocardite linfocítica difusa, com edema intersticial e miocitólise, com boa resposta ao tratamento imunossupressor. O diagnóstico diferencial através da BEM com miocardite de células gigantes ou miocardite eosinofílica necrotizante tem importância prognóstica.

Miocardite de células gigantes - Inflamação crônica difusa acompanhada de células gigantes, ocorrendo usualmente em pacientes com outras doenças autoimunes.

Miocardite necrotizante eosinofílica - É uma condição uma rara, com infiltrado inflamatório difuso, predomínio de eosinófilos e extensa necrose.

Miocardite aguda - A BEM revela diferentes intensidades de inflamação, geralmente um infiltrado linfo-histiocitário, edema intracelular e intersticial, com presença de miocitólise focal ou difusa.

Miocardite crônica ativa - É a forma frequente de miocardite em adultos a BEM mostra miocardite linfocítica ativa ou borderline, alterações degenerativas da fibra com hipertrofia e fibrose intersticial a contagem de linfócitos pode melhorar a acuidade do diagnóstico: mais de 7 linfócitos $/ \mathrm{mm}^{2}$ miocardite discreta e mais de $14 \mathrm{~mm}^{2}$ miocardite moderada.

Doenças de depósito - colorações específicas para amilóide, ferro, mucopolissacarídeos e outras devem ser realizadas. A microscopia eletrônica auxilia e muitas vezes confirmar o diagnóstico.

Cardiotoxicidade - A microscopia eletrônica é fundamental para diagnosticar precocemente as alterações, como as induzidas por antraciclina, com extensa lise miofibrilar, ruptura mitocondrial e vacuolização intramiócito ${ }^{82}$, gradação de toxicidade.

\subsubsection{Análise histológica por imuno-histoquímica}

Para a análise de imunohistoquímica do tecido miocárdico, devemos utilizar no mínimo dois fragmentos obtidos pela biópsia endomiocárdica, que devem ser conservados em formalina tamponada a 10\%, na temperatura ambiente, sem serem congelados. A avaliação diagnóstica da miocardite pela imuno-histoquímica oferece maior acurácia na detecção da presença de processo inflamatório miocárdico do que se tem através dos critérios histológicos. A imuno-histoquímica, através da análise de reações antígeno-anticorpo específicos, realiza a marcação das células mononucleares (linfócitos T e B) e de leucócitos através de anticorpos específicos, o que permite melhor identificação e contagem das células inflamatórias. A imuno-histoquímica também identifica a ativação inflamatória induzida pelas citocinas, através da detecção de antígenos de histocompatibilidade (HLADR) do tipo I e II nas células endoteliais ou intersticiais dos cardiomiócitos ou perivasculares e da expressão de receptores na superfície celular para a adesão das células inflamatórias (ICAM) ${ }^{83-85}$. A imunohistoquímica, por detectar o infiltrado inflamatório e a capacidade de adesão celular induzida pelas citocinas, permite diagnosticar a agressão inflamatória miocárdica mesmo distante do foco primário de infecção o que lhe confere uma maior acurácia do que a análise histológica convencional no diagnóstico das miocardites através da biópsia do ventrículo direito ${ }^{86,87}$.

O aumento da expressão miocárdica dos antígenos de histocompatibilidade (HLADR) e das moléculas de adesão (ICAM) pode ser difuso ou localizado, e usualmente está associado à presença de células inflamatórias com contagem de linfócitos $\mathrm{T}(\mathrm{CD} 3)$ superior a duas células por campo de microscopia ótica $(\times 400)$ que correspondem a $7 \bullet 0$ células $/ \mathrm{mm}^{2}{ }^{88-90}$.

Podemos estabelecer o diagnóstico de miocardite através de um escore de pontos que combina a expressão do HLADR com a presença de infiltrado inflamatório ${ }^{91,92}$.

\begin{tabular}{cl}
\hline Pontos & \multicolumn{1}{c}{ Critério } \\
\hline 0 & $\begin{array}{l}\text { Ausência ou leve detecção de HLADR em células } \\
\text { endoteliais e intersticiais. }\end{array}$ \\
\hline 1 & $\begin{array}{l}\text { Presença focal de HLADR em células endoteliais e } \\
\text { intersticiais }\end{array}$ \\
\hline 2 & Presença multifocal de HLADR restrita às células endoteliais \\
\hline 3 & $\begin{array}{l}\text { Presença de HLADR difusa nas células endoteliais e } \\
\text { focal nos cardiomiócitos }\end{array}$ \\
\hline 4 & $\begin{array}{l}\text { Presença de HLADR difusa nas células endoteliais e } \\
\text { cardiomiócitos }\end{array}$ \\
\hline
\end{tabular}

Devemos considerar como diagnóstico positivo para miocardite a presença de um escore igual ou superior a três para HLADR positivo ou dois ou mais para ICAM-1 positivo, associado à presença de infiltrado de células inflamatórias igual ou superior a $7 \bullet 0$ células $/ \mathrm{mm}^{2}$. O escore entre um e três reconhece-se como possível diagnóstico de inflamação.

Podemos considerar também como diagnóstico positivo a contagem de linfócitos igual ou superior a $14 \bullet 0$ celulas $/ \mathrm{mm}^{2}$ sendo que na presença de menos de 14 células podemos utilizar a contagem de linfócitos para a confirmação de miocardite ${ }^{37,93}$.

A tabela 9 demonstra as indicações para realização da imunohistoquímica na miocardite.

Tabela 9 - Indicação de imunohistoquímica para o diagnóstico de miocardite.

\begin{tabular}{ccc}
\hline $\begin{array}{c}\text { Classe de } \\
\text { recomendação }\end{array}$ & Indicações & $\begin{array}{c}\text { Nível de } \\
\text { evidência }\end{array}$ \\
\hline Classe I & $\begin{array}{c}\text { Imunohistoquímica com HLADR tipo I e II } \\
\text { na investigação diagnóstica de inflamação } \\
\text { miocárdica. }\end{array}$ & B \\
\hline Classe I & $\begin{array}{c}\text { Imunohistoquímica para pesquisa e } \\
\text { contagem de infiltrado por linfócitos T, B e } \\
\text { macrófagos. }\end{array}$ & B \\
\hline
\end{tabular}




\section{Diretrizes}

\section{Tratamento}

5.1. Medidas gerais e preventivas: hábitos de vida, exercício e dieta

As medidas gerais no tratamento da miocardite objetivam cuidados relacionados às formas sintomáticas ou não de insuficiência cardíaca (estágios B a D). A restrição dietética do sódio a 2 a $3 \mathrm{~g} / \mathrm{dia}$ é indicada na ausência de hiponatremia e restrição calórica, sendo coadjuvante fundamental nas fases mais avançadas de apresentação clínica. A restrição hídrica entre 1000 e $1500 \mathrm{ml}$ por dia também é recomendada na fase sintomática.

O tabagismo, bem como o consumo excessivo do álcool, é contraindicado, havendo orientação de vigilância do peso corporal para evitar-se tanto a obesidade como a caquexia. Os anti-inflamatórios não hormonais não devem ser associados na fase aguda e na presença de insuficiência cardíaca ${ }^{94,95}$. Em relação aos exercícios físicos, estudos em animais mostram que atividade aeróbica durante a fase aguda da doença leva a aumento de mortalidade ${ }^{96}$. Em vista disso e sabendo-se que miocardite é causa de morte súbita em atletas jovens ${ }^{97}$, os pacientes não devem realizar exercícios vigorosos por até seis meses após a fase aguda, e até por mais tempo na dependência dos sintomas ou se restou comprometimento da função ventricular ${ }^{98,99}$.

Em relação à prevenção, as vacinas disponíveis (caxumba, sarampo, rubéola, poliomielite e gripe) devem ser administradas para que a miocardite secundária aos agentes dessas doenças seja evitada, e não se deve não realizar a vacinação enquanto houver com atividade de doença. Estudos em modelos animais mostram que a vacina contra o vírus da gripe previne o dano miocárdico, mas não há estudos em humanos ${ }^{100 .}$

A tabela 10 resume as indicações de medidas não farmacológicas na miocardite.

Tabela 10 - Recomendações de medidas não farmacológicas na miocardite.

\begin{tabular}{|c|c|c|}
\hline $\begin{array}{l}\text { Classe de } \\
\text { recomendação }\end{array}$ & Indicações & $\begin{array}{l}\text { Nível de } \\
\text { evidência }\end{array}$ \\
\hline Classe I & $\begin{array}{l}\text { Ingestão de } 2 \text { a } 3 \text { g de sódio/dia em } \\
\text { pacientes com insuficiência cardíaca }\end{array}$ & C \\
\hline Classe I & $\begin{array}{l}\text { Restrição hídrica de } 1000 \text { a } 1500 \mathrm{ml} / \mathrm{dia} \\
\text { em pacientes com insuficiência cardíaca }\end{array}$ & C \\
\hline Classe lla & $\begin{array}{l}\text { Vigilância do peso corpóreo, evitando } \\
\text { caquexia e obesidade }\end{array}$ & C \\
\hline Classe Ila & Vacinação fora de atividade de doença & C \\
\hline Classe III & $\begin{array}{c}\text { Exercícios durante ou até } 6 \text { meses após } \\
\text { a fase aguda }\end{array}$ & C \\
\hline Classe III & $\begin{array}{l}\text { Uso de antiinflamatórios não hormonais } \\
\text { na fase aguda ou na permanência de } \\
\text { disfunção ventricular na fase crônica }\end{array}$ & C \\
\hline Classe III & Tabagismo & $A$ \\
\hline
\end{tabular}

\subsection{Suporte terapêutico geral: betabloqueadores, IECA/} BRA, anticoagulação

A modulação do sistema renina-angiotensina-aldosterona atenua a progressão da disfunção ventricular, diminuindo a fibrose, necrose e inflamação miocárdica em modelos experimentais ${ }^{101,102}$. Os inibidores da enzima de conversão (IECA) e bloqueadores do receptor da angiotensina (BRA) são utilizados em todos os casos de pacientes com disfunção ventricular, mesmo naqueles sem insuficiência cardíaca manifesta, salvo contraindicações, com doses progressivas até as máximas preconizadas. Recomenda-se a manutenção dos IECA/BRA nos casos de normalização da função ventricular. Em um estudo no qual foi suspenso o IECA, cerca de um terço dos pacientes apresentaram novo episódio de insuficiência cardíaca contra $5 \%$ dos que mantiveram a medicação ${ }^{103}$. Os BRA podem ser utilizados na presença de disfunção ventricular e intolerância ao uso de IECA

O bloqueio beta-adrenérgico na miocardite baseia-se na necessidade de reduzir a atividade simpática e os níveis de noradrenalina, impedindo assim a progressão da disfunção miocárdica e um pior prognóstico. Os betabloqueadores (BB) são utilizados em todos os casos de pacientes com disfunção ventricular e insuficiência cardíaca manifesta, salvo contraindicações, com doses progressivas até as máximas preconizadas. Recomenda-se a manutenção do BB nos casos de normalização da função ventricular, pelo período mínimo de um ano.

O uso de anticoagulante oral (ACO) está indicado nos casos de miocardite associado a fibrilação atrial (FA) paroxística, ou permanente, trombos intracavitários ou fenômenos tromboembólicos prévios ${ }^{104}$.

A tabela 11 traz as recomendações de medidas farmacológicas na miocardite.

Tabela 11 - Recomendações de medidas farmacológicas gerais na miocardite.

\begin{tabular}{|c|c|c|}
\hline $\begin{array}{l}\text { Classe de } \\
\text { recomendação }\end{array}$ & Indicações & $\begin{array}{l}\text { Nível de } \\
\text { evidência }\end{array}$ \\
\hline Classe I & $\begin{array}{l}\text { IECA e BRA todos os pacientes, salvo } \\
\text { contra-indicações }\end{array}$ & C \\
\hline Classe I & BB com disfunção ventricular & C \\
\hline Classe I & ACO na FA paroxística ou permanente & C \\
\hline Classe lla & $\begin{array}{l}\text { IECA/BRA após normalização da função } \\
\text { ventricular }\end{array}$ & C \\
\hline Classe Ila & $\begin{array}{l}\text { BB após normalização da função } \\
\text { ventricular }\end{array}$ & C \\
\hline
\end{tabular}

\subsection{Terapia específica}

\subsubsection{Imunossupressão}

A terapêutica imunossupressora na miocardite tem como objetivo suprimir a resposta inflamatória e a atividade autoimune, com consequente melhora clínica e da função ventricular, além de redução da mortalidade. Para indicação da terapêutica imunossupressora, faz-se necessária a comprovação 
de atividade inflamatória miocárdica através da biópsia endomiocárdica associada a pesquisa viral negativa (Figura 2).

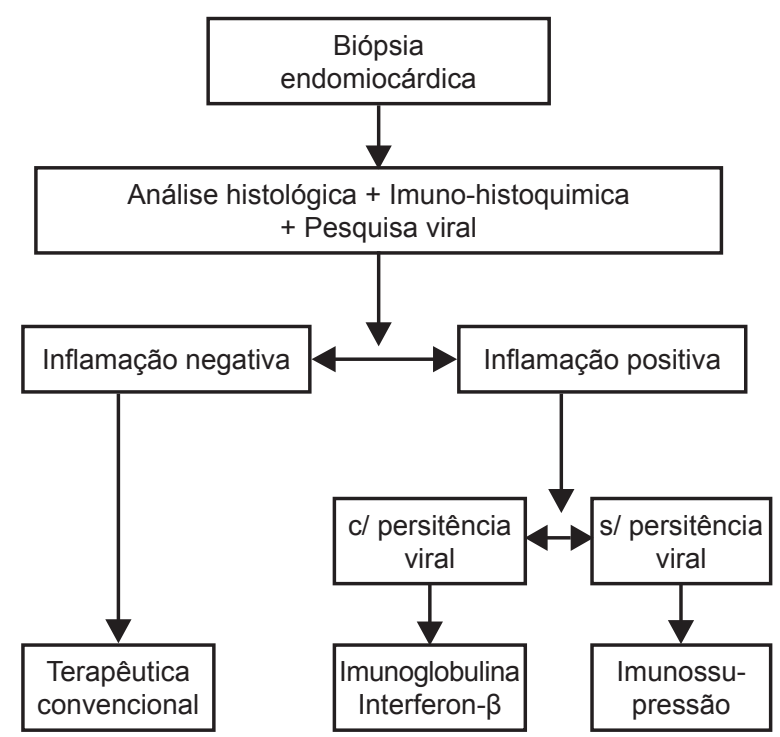

Figura 2 - Fluxograma terapêutico da miocardite viral

Fatores como a regressão espontânea da inflamação de cerca de $50 \%$ das miocardites, a falta de uniformidade dos estudos clínicos quanto aos critérios diagnósticos, o reduzido número de pacientes na maioria dos ensaios, a heterogeneidade das características clínicas das populações estudadas e a ausência de estudos clínicos com objetivo principal de avaliar a redução da mortalidade de forma isolada dificultam a análise dos benefícios clínicos da terapêutica imunossupressora. Os estudos clínicos ${ }^{105}$ que avaliaram a melhora na sobrevida não demonstraram benefício da terapêutica imunossupressora em relação à terapêutica convencional para insuficiência cardíaca. Esses estudos apresentaram diversas falhas metodológicas, como não realizar pesquisa viral, utilizar somente de critérios de análise histológica por DALLAS e não de imunohistoquímica para o diagnóstico de miocardite. Tudo isso pode ter comprometido os benefícios esperados com a terapêutica imunossupressora, por isso permanece não definido o benefício da imunossupressão na redução da mortalidade.

Em pacientes com IC crônica com miocardite ativa, sem presença de infecção viral, a terapêutica imunossupressora demonstrou benefícios na melhora clínica, redução dos diâmetros cavitários com melhora da função ventricular e regressão da atividade inflamatória (tabela 12) ${ }^{106-109}$. Nas miocardites autoimune, eosinofílica por hipersensibilidade, sarcoidose ou por células gigantes, a terapêutica com corticosteroides ou associada à ciclofosfamida (lúpus eritematoso) demostra benefícios na melhora clínica, da função ventricular e da sobrevida, mas deve-se considerar que esses benefícios foram observados em estudos com número reduzido de pacientes ${ }^{110-112}$.
A terapêutica imunossupressora mais comumente utilizada nos pacientes com miocardite pós-viral é a associação de prednisona com azatioprina pelo período de seis meses (tabela 13). Os pacientes submetidos à terapêutica imunossupressora devem ser clinicamente monitorados de modo contínuo quanto ao desenvolvimento de paraefeitos, pois estes podem aumentar de forma significativa tanto a morbidez quanto a mortalidade.

Tabela 12 - Indicações da terapêutica imunossupressora na miocardite.

\begin{tabular}{ccc}
\hline $\begin{array}{c}\text { Classe de } \\
\text { recomendação }\end{array}$ & Indicações & $\begin{array}{c}\text { Nível de } \\
\text { evidência }\end{array}$ \\
\hline Classe I & $\begin{array}{c}\text { Na presença de miocardite positiva - por } \\
\text { células gigantes, doenças autoimunes, } \\
\text { sarcoidose e hipersensibilidade - } \\
\text { associada a disfunção ventricular. }\end{array}$ & B \\
\hline Classe Ila & $\begin{array}{c}\text { Na presença de miocardite positiva com } \\
\text { pesquisa viral negativa, comprovada por } \\
\text { biópsia endomiocárdica, em pacientes com } \\
\text { insuficiência cardíaca crônica, com objetivo } \\
\text { de melhora clinica e da função ventricular. }\end{array}$ & B \\
\hline Classe III & $\begin{array}{l}\text { Na insuficiência cardiaca aguda não } \\
\text { responsiva a terapêutica usual. }\end{array}$ & C \\
\hline
\end{tabular}

Tabela 13 - Terapêutica imunossupressora com prednisona e azatioprina.

\begin{tabular}{cc}
\hline & Prednisona \\
\hline $\begin{array}{c}\text { Primeiras } 4 \\
\text { semanas }\end{array}$ & $1 \mathrm{mg} / \mathrm{Kg} / \mathrm{dia}$ \\
\hline 5 a 12 semanas & Reduzir a posologia em $0,08 \mathrm{mg} / \mathrm{kg} / \mathrm{semana}$ \\
\hline 13 a 20 semanas & Manter a dose em 0,3mg/kg/dia \\
\hline 21 a 24 semanas & Reduzir a dose em 0,08mg/kg/semana \\
\hline & Azatioprina \\
\hline 1 a 24 semanas & $2 \mathrm{mg} / \mathrm{kg} / \mathrm{dia}$ \\
\hline
\end{tabular}

\subsubsection{Antivirais}

A terapêutica antiviral tem como objetivo promover a eliminação viral como também impedir a sua replicação. Dentre as possibilidades terapêuticas, temos a infusão subcutânea de interferon- $\beta$ (IFN- $\beta$ ) e a imunoglobulina intravenosa (IG-IV).

Em modelo experimental de miocardite viral com animais geneticamente modificados para não expressão de produção de IFN- $\beta$, foi observada extensa proliferação viral e intensa atividade inflamatória associada a maior disfunção ventricular e mortalidade, sugerindo que o IFN- $\beta$ tem um importante papel para o controle da infecção viral na miocardite ${ }^{113}$.

A infusão subcutânea de IFN- $\beta$ em pacientes com cardiomiopatia dilatada e persistência viral (adenovírus e enterovírus) demonstrou eliminação viral com melhora clínica da capacidade funcional e função ventricular ${ }^{100}$. Em pacientes com miocardite viral por parvovírus-B19, o IFN- $\beta$ esteve associado à redução da carga viral, melhora da função 
endotelial e da função ventricular ${ }^{114}$. Portanto, a terapêutica com IFN- $\beta$ em pacientes com miocardite viral está se consolidando como opção terapêutica antiviral.

A imunoglobulina-IV (IG-IV) apresenta atuações antiinflamatórias, redução da resposta imune e antiviral. Ela promove a redução da ativação e ação das citocinas pró-inflamatórias, possui propriedade anti-idiotípica com consequente redução da produção e neutralização dos autoanticorpos. A IG-IV apresenta ainda ação antiviral por reduzir a replicação e favorecer a eliminação viral ${ }^{99}$.

A utilização da IG-IV em cardiomiopatia dilatada de início recente não demonstrou benefício na melhora da função ventricular frente ao placebo. Porém, algumas falhas na metodologia podem ter comprometido os resultados apresentados, pois os pacientes foram admitidos no estudo com ou sem inflamação presente na biópsia, a inflamação foi somente demonstrada somente em $16 \%$ dos pacientes e neste não foi pesquisada presença viral. O critério histológico de DALLAS foi utilizado para o diagnóstico de inflamação ${ }^{99}$.

Em miocardites virais por adenovírus e citomegalovírus, a IG-IV ocasionou redução da carga viral e da inflamação com melhora clínica e da função ventricular. Na miocardite por PV-B19 temos uma persistência de carga viral em cerca de $40 \%$ dos pacientes após a utilização da IG-IV, sendo que os pacientes que tiveram eliminação do PV-B19 evoluíram com melhora da função ventricular e redução dos diâmetros cavitários ${ }^{115}$. Esses resultados sugerem que o benefício terapêutico da IG-IV deve ser reservado ao cenário de miocardites com processo inflamatório ativo, avaliado por imunohistoquímica, e identificação viral positiva (tabela 14).

Tabela 14 - Recomendações da terapêutica antiviral com imunoglobulina na miocardite

\begin{tabular}{ccc}
\hline $\begin{array}{c}\text { Classe de } \\
\text { recomendação }\end{array}$ & Indicações & $\begin{array}{c}\text { Nível de } \\
\text { evidência }\end{array}$ \\
\hline Classe Ila & $\begin{array}{c}\text { Na presença de miocardite positiva, } \\
\text { comprovada por biópsia endomiocárdica } \\
\text { e pesquisa positiva para adenovirus, } \\
\text { CMV,enterovirus e parvovirus B19, } \\
\text { com objetivo de melhora clinica e da } \\
\text { função ventricular. }\end{array}$ & B \\
\hline Classe IIb & $\begin{array}{c}\text { Na presença de miocardite } \\
\text { positiva, comprovada por biópsia } \\
\text { endomiocárdica e pesquisa positiva para } \\
\text { adenovirus,CMV,enterovirus e parvovirus } \\
\text { B19 em pacientes com insuficiência cardíaca } \\
\text { crônica, com objetivo de melhora clinica } \\
\text { e da função ventricular. }\end{array}$ & B \\
\hline Classe III & $\begin{array}{l}\text { Uso de IG em pcts com IC Aguda não } \\
\text { responsiva ao tratamento clinico,sem } \\
\text { avaliação por biopsia endomiocárdica }\end{array}$ & C \\
\hline
\end{tabular}

\subsubsection{Imunomodulação}

O processo de imunomodulação tem como objetivo reduzir a agressão inflamatória e autoimune através da remoção e modulação de possíveis agentes agressores envolvidos na patogênese da miocardite.

A terapia de imunoadsorção através de plasmaférese seletiva visa a retirada de autoanticorpos específicos associada à terapia com IG-IV para imunomodulação inflamatória das citocinas e da produção dos autoanticorpos. A utilização da imunoadsorção em pacientes com cardiomiopatia inflamatória crônica com níveis séricos elevados de autoanticorpos contra $\beta 1$ neurorreceptor miocárdico associado à reposição de IG-IV, demonstrou redução da atividade inflamatória miocárdica e melhora clínica da classe funcional e da função ventricular e maior sobrevida ao fim de cinco anos. Embora esses resultados sugiram um possível benefício desta terapêutica nos pacientes com miocardite autoreativa, o número de pacientes avaliados é muito reduzido para que possamos estabelecer essa estratégia terapêutica como definitiva ${ }^{116}$.

A pentoxifilina apresenta como propriedades antiinflamatórias o bloqueio da transcriptase do TNF- $\alpha$ e a redução dos níveis de interleucinas 2 e 6, com consequente redução dos efeitos de cardioagressão dessas citocinas ${ }^{117}$.

Na cardiomiopatia dilatada com IC crônica e na cardiomiopatia periparto, a utilização de pentoxifilina na posologia de $1200 \mathrm{mg}$ a $2400 \mathrm{mg} /$ dia, pelo período de seis meses, ocasionou melhora clínica da classe funcional e da função ventricular (tabela 15). Esses resultados sugerem um papel benéfico da pentoxifilina como terapêutica coadjuvante nas cardiomiopatias inflamatórias crônicas, sendo ainda necessário ainda comprovar este benefício nas cardiomiopatias de início recente ou miocardites agudas ${ }^{118-121}$.

Tabela 15 - Recomendação de utilização de pentoxifilina como imunomodulador.

\begin{tabular}{ccc}
\hline $\begin{array}{c}\text { Classe de } \\
\text { recomendação }\end{array}$ & Indicação & $\begin{array}{c}\text { Nível de } \\
\text { evidência }\end{array}$ \\
\hline Classe llb & $\begin{array}{c}\text { Utilização de pentoxifilina nas } \\
\text { cardiomiopatia inflamatória crônica ou } \\
\text { cardiomiopatia periparto, para melhora } \\
\text { clínica e da função ventricular }\end{array}$ & B \\
\hline
\end{tabular}

\section{Situações especiais}

\subsection{Tratamento de arritmias e prevenção da morte súbita}

Os pacientes que se encontram na fase aguda de miocardite podem desenvolver tanto taquiarritmias como bradiarritmias. Essas arritmias frequentemente desaparecem após a fase aguda da miocardite, sendo a terapia, habitualmente, de suporte.

Geralmente não se recomenda terapia antiarrítmica para extrassístoles atriais e ventriculares assintomáticas. As taquicardias supraventriculares (TSV), principalmente fibrilação e flutter atrial, podem induzir ou agravar a IC. A abordagem inicial recomendada para a TSV sustentada sintomática é a restauração do ritmo sinusal através de cardioversão elétrica ou química. Para TSV sustentada recorrente, as opções incluem a ablação por cateter ou o controle da frequência ventricular.

Taquicardias ventriculares não sustentadas assintomáticas não devem receber terapia específica. As arritmias ventriculares sustentadas devem ser tratadas com drogas antiarrítmicas após a reversão elétrica aguda. A opção, porém, é limitada a amiodarona. Devido aos efeitos pró-arrítmicos, drogas de classe I e III (exceto a amiodarona) são geralmente evitadas nesses pacientes.

Bloqueio átrioventricular total e bradicardia sinusal sintomática são indicações para estimulação provisória durante a fase aguda da miocardite. Essas anormalidades de condução muitas vezes são transitórias. 
Não existem dados disponíveis na literatura sobre os riscos em longo prazo de pacientes que apresentam TV ou PCR na fase aguda da miocardite, de modo que a conduta nestes casos é individualizada. O implante de cardiodesfibrilador (CDI) está indicado, na presença de terapia medicamentosa otimizada, em pacientes que desenvolvem cardiomiopatia dilatada na fase crônica da miocardite, com os critérios descritos na tabela 16 .

Tabela 16 - Tratamento de arritmias e prevenção de morte súbita na miocardite.

\begin{tabular}{|c|c|c|}
\hline $\begin{array}{l}\text { Classe de } \\
\text { recomendação }\end{array}$ & Indicações & $\begin{array}{l}\text { Nível de } \\
\text { evidência }\end{array}$ \\
\hline Classe I & $\begin{array}{l}\text { Implante de marcapasso transvenoso } \\
\text { provisório em pacientes com bradicardia } \\
\text { sintomática e/ou bloqueio AV durante a } \\
\text { fase aguda da miocardite }\end{array}$ & C \\
\hline Classe I & $\begin{array}{l}\text { Terapêutica com betabloqueador em } \\
\text { doses otimizadas para prevenção de } \\
\text { morte súbita em pacientes com miocardite }\end{array}$ & $A$ \\
\hline Classe Ila & $\begin{array}{l}\text { Implante de CDI na Prevenção Primária } \\
\text { de MS em pacientes com cardiomiopatia } \\
\text { dilatada na fase crônica da miocardite, CF } \\
\text { II-III, com FEVE } \leq 35 \% \text { e expectativa de } \\
\text { vida de pelo menos } 1 \text { ano }\end{array}$ & A \\
\hline Classe Ila & $\begin{array}{l}\text { Implante de CDI na Prevenção Primária } \\
\text { de MS em pacientes com cardiomiopatia } \\
\text { dilatada na fase crônica da miocardite } \\
\text { (> } 6 \text { meses), CF III-IV, QRS } \geq 150 \text { ms, } \\
\text { com FEVE } \leq 35 \% \text {, para os quais tenha } \\
\text { sido indicado TRC e expectativa de vida } \\
\text { de pelo menos } 1 \text { ano }\end{array}$ & B \\
\hline Classe Ila & $\begin{array}{l}\text { Terapia antiarrítmica com amiodarona } \\
\text { na TVNS sintomática ou TV sustentada } \\
\text { durante a fase aguda de miocardite }\end{array}$ & C \\
\hline Classe III & $\begin{array}{l}\text { Atividade física durante a fase aguda } \\
\text { da miocardite }\end{array}$ & C \\
\hline Classe III & $\begin{array}{l}\text { Indicação de CDI nas fases aguda e } \\
\text { subaguda de miocardite ( }<6 \text { meses) }\end{array}$ & C \\
\hline
\end{tabular}

\subsection{Miocardite fulminante}

Classicamente a miocardite fulminante e uma forma mais grave de manifestação da miocardite aguda, caracterizada por um curso agudo de doença, rapidamente progressiva, com ICC CF IV e choque cardiogênico e de alta letalidade quando não tratada com suporte hemodinâmico adequado ${ }^{122}$.

Na miocardite fulminante viral usualmente ocorre a persistência de uma alta viremia em indivíduos susceptíveis, com persistência da ativação de linfócitos T e formação de anticorpos responsáveis pela mediação da agressão e destruição miocitária ${ }^{22}$.

Felker e colaboradores descreveram as características da miocardite fulminante, na apresentação clínica, em período longo de seguimento de pacientes ${ }^{123}$. Esses pacientes frequentemente tiveram quadro de processo infeccioso detectado nas últimas quatro semanas e também quadro febril nas últimas 12 semanas. A apresentação é aguda, progressiva e a grande maioria dos pacientes já se encontram em CF III/IV por ocasião do seu diagnóstico. Além disso, em comparados com o que ocorre na forma não fulminante, estes pacientes são mais hipotensos, taquicárdicos e com menos dilatação ventricular.

Apesar de apresentar um quadro de dramática evolução, quando se faz o reconhecimento precoce do seu diagnóstico e as medidas de suporte clínico e hemodinâmico são adotadas imediatamente, o prognóstico pode ser muito bom, inclusive com reversão da disfunção ventricular e boa sobrevida tardia ${ }^{124,125}$.

Do ponto de vista do tratamento específico da miocardite, o reconhecimento do fator causal através da investigação histológica por BEM permite o estabelecimento de estratégias terapêuticas específicas, como a utilização de imunoglobulina nas miocardites virais e imunossupressão nas autoimunes sem presença viral, ou com o uso de corticoide em pacientes com sarcoidose ou miocardite por células gigantes. Uma opção que tem sido testada é a utilização de altas doses de imunoglobulina, que se mostrou efetiva em série de casos, porém ainda sem comprovação por estudo randomizado ${ }^{126,127}$. O tratamento de suporte deve ser realizado com drogas vasoativas e eventualmente vasopressoras, e em situações nas quais seja possível a introdução de vasodilatadores. $\mathrm{O}$ insucesso imediato no tratamento medicamentoso e acerto volêmico deve abrir perspectiva para indicação de suporte hemodinâmico com assistência circulatória. Os dispositivos mais utilizados são o balão intra-aórtico, dispositivos percutâneos como tandem-heart e impella, a circulação extracorpórea (ECMO) e ventrículos artificiais paracorpóreos, como ponte para recuperação ou ponte para transplante cardíaco. Os dispositivos de curta duração têm sua indicação para suporte de 7 a 10 dias $^{128}$. Após esse período, e quando não se consegue a estabilização do paciente, a indicação de ECMO ou ventrículos artificiais pode dar suporte por período maior, possibilitando mais chance de recuperação da disfunção ventricular ${ }^{129}$.

As indicações na miocardite fulminante encontram-se na tabela 17.

Tabela 17 - Indicações na miocardite fulminante.

\begin{tabular}{|c|c|c|}
\hline $\begin{array}{l}\text { Classe de } \\
\text { recomendação }\end{array}$ & Indicações & $\begin{array}{l}\text { Nível de } \\
\text { evidência }\end{array}$ \\
\hline Classe I & $\begin{array}{l}\text { Na presença de miocardite positiva - por } \\
\text { células gigantes, doenças autoimunes, } \\
\text { sarcoidose e hipersensibilidade }\end{array}$ & B \\
\hline Classe I & $\begin{array}{l}\text { Suporte hemodinâmico e com dispositivos } \\
\text { de assistência ventricular temporários } \\
\text { na suspeita de miocardite em sua forma } \\
\text { fulminante, no insucesso terapêutico com } \\
\text { drogas vasoativas e balão intra-aórtico. }\end{array}$ & $B$ \\
\hline Classe I & $\begin{array}{l}\text { Transplante cardíaco em situação } \\
\text { de prioridade, para pacientes que } \\
\text { não apresentam melhora clínica } \\
\text { e hemodinâmica, a despeito do } \\
\text { tratamento instituído. }\end{array}$ & B \\
\hline Classe I & $\begin{array}{l}\text { Suporte circulatório com dispositivos } \\
\text { de longa permanência, quando não } \\
\text { ocorre melhora do quadro clínico e } \\
\text { hemodinâmico mesmo com suporte } \\
\text { temporário por mais de } 10 \text { dias. }\end{array}$ & B \\
\hline Classe I & $\begin{array}{l}\text { Realização de biópsia endomiocárdica na } \\
\text { apresentacão fulminante de miocardite }\end{array}$ & C \\
\hline
\end{tabular}




\section{Diretrizes}

\begin{tabular}{ccc}
\hline $\begin{array}{c}\text { Classe de } \\
\text { recomendação }\end{array}$ & Indicações & $\begin{array}{c}\text { Nível de } \\
\text { evidência }\end{array}$ \\
\hline & $\begin{array}{c}\text { Utilização de imunoglobulina endovenosa } \\
\text { em pacientes com apresentação } \\
\text { Clínica de miocardite fulminante, após } \\
\text { comprovação de infecção viral por } \\
\text { meio de biópsia endomiocárdica, não } \\
\end{array}$ & B \\
& responsiva às medidas de suporte iniciais. & \\
\hline
\end{tabular}

\subsection{Cardiomiopatia neuroadrenérgica (Takotsubo)}

A cardiomiopatia neuroadrenérgica (CNA) tem sido progressivamente mais diagnosticada nos pacientes com disfunção ventricular aguda nas salas de emergência. As mulheres idosas (pós-menopausa) representam o principal grupo de risco (em torno de $80 \%$ dos casos), sendo que a cardiomiopatia é frequentemente desencadeada por intenso estresse físico ou emocional, perdas financeiras, desastres naturais e por vezes secundária a estresse provado por outras doenças. A CNA apresenta bom prognóstico: com mortalidade intra-hospitalar de $2 \%$ e, geralmente, usualmente com recuperação da função cardíaca entre 2-4 semanas ${ }^{130}$.

Os principais achados clínicos são a presença de dor torácica, dispneia e síncope. Alterações eletrocardiográficas são comuns, como supradesnivelamento do segmento ST (34 a 56\%), ondas Q patológicas inversão da onda T com QT prolongado, além de alterações inespecíficas da repolarização. A elevação dos níveis de troponinas cardíacas é frequente e o pequeno aumento das troponinas é discrepante com as anormalidades contráteis e hemodinâmicas ${ }^{131}$. A ventriculografia esquerda, ou estudo ecodopplercardiográfico, demonstra abaulamento apical com acinesia ou discinesia acometendo de metade a dois terços do VE associada a hiperdinamia dos segmentos basais. A ressonância cardíaca com gadolíneo é útil para diferenciar o CNA do IAM e da miocardite, por não demonstrar presença de edema miocárdico ou realce tardio. Podemos identificar o acometimento do ventrículo direito em 25\% dos casos. As principais complicações agudas são: insuficiência cardíaca, taquicardia ventricular, fenômenos trombo-embólicos, regurgitação mitral e choque cardiogênico.

A CNA apresenta bom prognóstico evolutivo em contraste, por vezes, com a avaliação clínica com importante comprometimento hemodinâmico. O tratamento tem como base manter o suporte clíinico-hemodinâmico, para permitir a recuperação espontânea do miocárdio. $\mathrm{Na}$ ausência de hipotensão arterial ou sinais de baixo débito cardíaco, podem ser utilizados betabloqueador, inibidor da enzima conversora e diurético. Pacientes que cursam com hipotensão arterial necessitam de suporte hemodinâmico com uso cauteloso de inotrópicos, como dobutamina, e vasopressores na presença de hipotensão refratária. E caso não ocorra melhora clínicohemodinâmica está indicado o suporte hemodinâmico mecânico com balão intra-aórtico. Em pacientes que estejam evoluindo com choque refratário, o emprego da circulação extracorpórea (ECMO) pode ser realizado, tendo em vista o perfil transitório da síndrome.

As Indicações para o diagnóstico de Takotsubo encontramse na tabela 18.
Tabela 18 - Indicações para o diagnóstico de Takotsubo.

\begin{tabular}{ccc}
\hline $\begin{array}{c}\text { Classe de } \\
\text { recomendação }\end{array}$ & Indicações & $\begin{array}{c}\text { Nível de } \\
\text { evidência }\end{array}$ \\
\hline Classe I & $\begin{array}{c}\text { Cinecoronariografia em pacientes } \\
\text { com suspeita diagnóstica de síndrome } \\
\text { de Takotsubo com apresentação } \\
\text { clínica com dor precordial e } \\
\text { supradesnivelamento do segmento ST. }\end{array}$ & $\mathrm{C}$ \\
\hline Classe I & $\begin{array}{c}\text { Ecocardiograma transtorácico para } \\
\text { avaliação diagnóstica inicial de suspeita de } \\
\text { síndrome de takotsubo. }\end{array}$ & $\mathrm{C}$ \\
\hline \multicolumn{4}{c}{$\begin{array}{c}\text { RNM para confirmação diagnóstica } \\
\text { de síndrome de Takotsubo quando } \\
\text { houver dissociação entre anormalidades } \\
\text { segmentares com lesões na anatomia } \\
\text { coronariana. }\end{array}$} & $\mathrm{C}$ \\
\hline
\end{tabular}

\subsection{Miocardite chagásica}

A doença de Chagas é endêmica na América Latina ${ }^{132}$. A miocardite chagásica pode se apresentar-se como miocardite aguda durante infecção "de novo" pelo Trypanosoma cruzi associada a várias formas de transmissão, incluindo a vertical como miocardite crônica, durante a evolução tardia após a infecção por esse agente: ser secundaria a reativação da infecção; congênita durante redução da imunocompetência, principalmente após o uso de imunodepressores, ou por infecção pelo vírus HIV.

A manifestação da miocardite aguda depende do grau de acometimento do coração e da infecção sistêmica, podendo variar de uma forma florida com taquicardia sinusal, baixa voltagem do QRS, distúrbio de condução, alteração do intervalo Q-T, sinais de alterações de repolarização ventricular, arritmias, comprometimento da função biventricular e insuficiência cardíaca aguda até as formas mais frustras em que é necessária a suspeita clínica para o diagnóstico ${ }^{13}$. Deve ser sempre suspeitada em pacientes de região endêmica, com possibilidade de transmissão vetorial ou de outras formas de transmissão como transfusão sanguínea, oral, ou ainda congênita. Pode estar associada a sinais de infecção sistêmica, hepatoesplenomegalia, febre e sinais de entrada do parasita na transmissão vetorial. A manifestação da reativação da infecção pelo Trypanosoma cruzi determinada pelo comprometimento da imunocompetência, pode ser semelhante à da miocardite aguda, mas as manifestações sistêmicas que a acompanham podem ser mais diversas, podendo acometer pele com chagomas e eritemas, medula óssea, meningoencefalite, além de febre e hepatoesplenomegalia. Na biópsia pode ser difícil o diagnóstico diferencial entre a miocardite da reativação e a rejeição ${ }^{133}$. Na forma congênita pode haver icterícia, hemorragia cutânea e sinais neurológicos, especialmente em neonatos prematuros. $\mathrm{O}$ aspecto anatomopatológico é de um processo inflamatório agudo, com apoptose, mas ainda sem fibrose importante. O diagnóstico se faz através da localização do parasita no miocárdio, ou na sua impossibilidade, a presença do parasita na circulação é forte evidência para o seu diagnóstico. Os métodos mais comumente utilizados para sua demonstração no sangue são o esfregaço, e o xenodiagnóstico. Em nosso meio, para o tratamento da forma aguda ou reativada, são utilizadas medicações específicas, como o benzonidazolna dose de $5-10 \mathrm{mg} / \mathrm{kg} /$ dia durante 30 a 60 dias para adultos e para crianças $15 \mathrm{mg} / \mathrm{kg} / \mathrm{dia}$, com elevado índice de sucesso. Nas reativações também o alopurinol foi utilizado com sucesso. 
A miocardite crônica pode ser encontrada na forma crônica da doença de Chagas - que pode se manifestar após longo período de latência pós-infecção aguda, de maneira isolada ou combinada -, na forma de insuficiência cardíaca crônica ou aguda, arritmias, morte súbita e embolia pulmonar ou sistêmica ${ }^{134,135}$. Os sinais e sintomas são de miocardiopatia, podendo haver maior incidência de bradicardia e distúrbio de condução, especialmente de ramo direito. Apresenta prognóstico pior do que outras etiologias ${ }^{136}$. Os mecanismos potencialmente envolvidos na sua patogenia são lesões neurogênicas, microvasculares, apoptose, processo inflamatório crônico, fibrose, persistência do parasita, e autoimunidade ${ }^{137}$. Atualmente se tem valorizado a persistência do parasita como mecanismo desencadeador da miocardite chagásica crônica ${ }^{138}$. Entretanto, outros agentes podem influenciar a manifestação da miocardite crônica ${ }^{139}$. Na fase crônica da doença de Chagas, diante de um diagnóstico clínico altamente provável, apoiado em dados de epidemiologia compatíveis, reações sorológicas positivas, manifestações típicas de insuficiência cardíaca ou de outros comprometimentos do coração, em geral não se realiza biópsia endomiocárdica. Outros métodos podem ser utilizados ${ }^{140}$. Na fisiopatologia, a insuficiência cardíaca pode determinar elevação de BNP e maior intensidade de processo pró-inflamatório ${ }^{141,142}$. O tratamento específico para as formas sem insuficiência cardíaca é controverso, e nas formas com insuficiência cardíaca é contraindicado ${ }^{143,144}$. O tratamento é o mesmo para outras formas de insuficiência cardíaca, quer na forma compensada, quer na descompensada ${ }^{145-148}$. Procedimentos cirúrgicos antes potencialmente favoráveis foram abandonados ${ }^{149-151}$ e no nos casos de evolução em estágio final está indicado o transplante cardíaco para melhora da qualidade de vida e sobrevida ${ }^{152-155}$ ou a utilização de dispositivos de assistência circulatória ${ }^{156}$. O transplante necessita de seguimento diferenciado devido ao maior número de comorbidades, incluindo neoplasia e reativação da infecção, mas tem resultado melhor do que para outras etiologias ${ }^{157-161}$.

Indicações para o diagnóstico e tratamento da miocardite chagásica estão na tabela 19.

Tabela 19 - Indicações para o diagnóstico e tratamento da miocardite chagásica.

\begin{tabular}{ccc}
\hline $\begin{array}{c}\text { Classe de } \\
\text { recomendação }\end{array}$ & Indicações & $\begin{array}{c}\text { Nível de } \\
\text { evidência }\end{array}$ \\
\hline Classe I & $\begin{array}{c}\text { Teste sorológico (2 técnicas distintas) para } \\
\text { o diagnóstico de miocardite chagásica em } \\
\text { crianças acima de 7 meses de idade }\end{array}$ & C \\
\hline Classe I & $\begin{array}{c}\text { Pesquisa do T.cruzi (por biópsia } \\
\text { endomiocárdica, de lesão de pele } \\
\text { ou de outro órgão quando houver } \\
\text { acometimento) em casos de reativação de } \\
\text { miocardite chagásica. }\end{array}$ & C \\
\hline Classe I & $\begin{array}{c}\text { Tratamento específico com benzonidazol } \\
\text { em casos de reativação de miocardite } \\
\text { chagásica. }\end{array}$ & C \\
\hline Classe lla & $\begin{array}{c}\text { Tratamento com alopurinol na ausência } \\
\text { de disfunção ventricular em pacientes } \\
\text { com reativação de miocardite chagásica. }\end{array}$ & C \\
\hline Classe llb & $\begin{array}{c}\text { Teste sorológico de rotina para } \\
\text { diagnóstico de reativação da infecção do }\end{array}$ & C cruzi \\
\hline
\end{tabular}

\section{Avaliação prognóstica}

A história natural das miocardites varia de acordo com a causa, sendo que dados clínicos e hemodinâmicos podem ajudar a estabelecer o prognóstico (tabela 20) ${ }^{13}$.

Existem diferentes formas clínicas e patológicas da miocardite, e a biópsia endomiocárdica pode estabelecer não somente o diagnóstico, mas também contribuir com a avaliação prognóstica. Isto pode ser feito, primeiramente, pela identificação de formas específicas de miocardite, como a miocardite fulminante, miocardite de células gigantes, miocardite ativa crônica, miocardite eosinofílica e sarcoidose. Os achados clinicopatológicos podem ajudar a diferenciar, por exemplo, miocardite linfocítica fulminante de miocardite linfocítica aguda, o que tem grande importância prognóstica (tabela 1) $)^{162}$. A miocardite linfocítica fulminante, que tem um início bem estabelecido com pródromos virais precedendo o quadro em duas semanas, caracteriza-se por grave comprometimento hemodinâmico. Entretanto, caso o tratamento consiga manter suporte vital adequado para o paciente (por vezes requerendo terapia inotrópica ou assistência circulatória mecânica), a chance de recuperação da função ventricular é grande, o que confere um bom prognóstico ao paciente ${ }^{163}$.

No passado, a baixa sensibilidade aliada à utilização única e exclusiva do critério de Dallas não permitia que achados da histologia pudessem ser bem correlacionados com a evolução do paciente ${ }^{45}$. Atualmente, a constatação da presença de vírus pode auxiliar a predizer essa evolução. Em um estudo observacional envolvendo 59 biópsias realizadas em 48 crianças com diagnóstico clínico e histológico de miocardite ou cardiomiopatia dilatada, a presença de PCR (reação em cadeia da polimerase) positiva para vírus revelou pior prognóstico, resultando em transplante cardíaco ou morte ${ }^{164}$.

Outro dado importante que frequentemente é capaz de predizer morte ou necessidade de transplante cardíaco é o comprometimento da função do ventrículo direito ${ }^{76}$.

\section{Tabela 20 - Miocardites e correlação dos seus cenários clínicos e} prognósticos.

\begin{tabular}{|c|c|}
\hline Cenário clínico & Prognóstico \\
\hline $\begin{array}{l}\text { Síndrome semelhante ao infarto agudo } \\
\text { do miocárdio com coronárias normais }\end{array}$ & $\begin{array}{l}\text { Bom, se a miocardite linfocítica está } \\
\text { presente na biópsia }\end{array}$ \\
\hline $\begin{array}{l}\text { Insuficiência cardíaca com } \\
\text { comprometimento hemodinâmico }\end{array}$ & $\begin{array}{l}\text { Bom na miocardite linfocítica } \\
\text { fulminante, mas o suporte pode } \\
\text { envolver terapia inotrópica ou } \\
\text { assistência circulatória mecânica }\end{array}$ \\
\hline $\begin{array}{c}\text { Insuficiência cardíaca com dilatação } \\
\text { do VE e novas arritmias ventriculares, } \\
\text { bloqueios avançados ou ausência de } \\
\text { resposta ao tratamento usual em } \\
\text { 1 a } 2 \text { semanas }\end{array}$ & $\begin{array}{l}\text { Ruim; alta probabilidade de morte ou } \\
\text { necessidade de transplante cardíaco } \\
\text { se miocardite de células gigantes } \\
\text { é encontrada na biópsia. Caso se } \\
\text { encontre sarcoidose aumenta o risco } \\
\text { da necessidade de marca-passo ou } \\
\text { desfibrilador }\end{array}$ \\
\hline $\begin{array}{l}\text { Insuficiência cardíaca com dilatação } \\
\text { do VE sem arritmias ventriculares ou } \\
\text { bloqueios avançados }\end{array}$ & $\begin{array}{l}\text { Bom nos primeiros anos, mas com } \\
\text { o risco de progressão tardia da } \\
\text { doença com insuficiência cardiaca } \\
\text { e cardiomiopatia caso genoma viral } \\
\text { esteja presente }\end{array}$ \\
\hline Insuficiência cardíaca com eosinofilia & Ruim \\
\hline
\end{tabular}




\section{Diretrizes}

\section{Pericardites}

\section{Epidemiologia}

Não existem dados epidemiológicos oficiais no Brasil referentes ao comprometimento pericárdico. Mesmo os disponíveis na literatura internacional são escassos e certamente sofrem a influência das características de cada centro. Os dados referentes a serviços de emergência mostram que $5 \%$ dos pacientes com queixa de dor torácica nos quais foi afastada insuficiência coronariana aguda ${ }^{165}$ e 1\% daqueles com supradesnível de segmento ST tinham pericardite aguda ${ }^{166}$.

Quanto ao derrame pericárdico, é mais frequente quando o comprometimento é por tuberculose ou neoplasia, e o mesmo acontece em relação ao tamponamento cardíaco. Já nos casos em que outras etiologias são responsáveis pelo quadro clínico, a frequência é menor.

\section{Classificação}

Pericardite é um processo inflamatório do pericárdio que tem múltiplas causas e se apresenta tanto como doença primária quanto secundária. Geralmente benigna e autolimitada, a pericardite pode cursar com derrame ou constrição pericárdica, o que aumenta sua morbidez ${ }^{167,168}$. As pericardites são classificadas de acordo com a evolução e forma de apresentação clínica ${ }^{153,169}$ :

- Pericardite aguda;

- Pericardite crônica;

- Derrame pericárdico e tamponamento cardíaco;

- Pericardite constritiva;

- Pericardite recorrente.

\section{Etiopatogenia}

As causas de pericardite são divididas em infecciosas e não-infecciosas (tabela 21). Entre as infecções pericárdicas, a pericardite viral é a mais comum e seu processo inflamatório deve-se à ação direta do vírus ou a uma resposta imune. Os mais comuns são: enterovírus, ecovírus, Epstein barr, herpes simples, influenza e citomegalovírus (CMV), sendo o último mais frequente em imunodeprimidos e soropositivos ${ }^{170}$. A pericardite nos soropositivos pode ser devida a doenças infecciosas, não infecciosas ou neoplásicas (sarcoma de Kaposi ou linfoma), podendo por vezes resultar em miopericardite ${ }^{25}$.

A pericardite bacteriana manifesta-se geralmente com derrame pericárdico, e sua origem pode estar em situações como pneumonia, empiema, disseminação hematogênica, pós-cirurgia cardíaca ou torácica - possui ampla gama de agentes infecciosos como causa. A pericardite tuberculosa tem diminuído com o controle efetivo da tuberculose pulmonar, mas mostra-se presente principalmente em pacientes HIV positivos $^{171,172}$.

Já o envolvimento autoimune do pericárdico acontece especialmente nos casos de lúpus eritematoso sistêmico, artrite reumatoide, esclerodermia, polimiosite e dermatomiosite.

A pericardite pós-infarto pode ocorrer precocemente nos três primeiros dias do infarto agudo do miocárdio (IAM), pericardite epistenocárdica. Nesses casos está relacionada ao acometimento do epicárdio e pericárdio adjacente e, tardiamente, de três semanas a seis meses, a atividade autoimune denominada síndrome de Dressler. A insuficiência renal é causa comum de doença pericárdica, produzindo derrame em $20 \%$ dos pacientes. Pode se manifestar como pericardite urêmica ou pericardite associada a diálise. Já as pericardites neoplásicas são devidas à invasão tumoral ou linfática, ou ocorrem por disseminação hematogênica ${ }^{167}$.

\section{Tabela 21 - Causas de pericardite.}

\begin{tabular}{|c|}
\hline Infecciosas \\
\hline $\begin{array}{c}\text { Viral (cocksackie, herpes, enterovírus, CMV, HIV, EBV, varicela, } \\
\text { rubéola, influenza, etc.) }\end{array}$ \\
\hline $\begin{array}{l}\text { Bacteriana (pneumococo, meningococo, hemophilus, chlamydia, } \\
\text { micobactérias, micoplasma, leptospira, etc) }\end{array}$ \\
\hline Fúngica (cândida, histoplasma) \\
\hline Parasitária (toxoplasma, entamoeba hystolitica, etc) \\
\hline Doenças do sistema autoimune \\
\hline $\begin{array}{l}\text { Lupus eritematoso sistêmico, artrite reumatoide, febre reumática, } \\
\text { esclerodermia, espondilite anquilosante, esclerose sistêmica, } \\
\text { dermatomiosite, periarterite nodosa, polimiosite, poliarterite nodosa, } \\
\text { púrpura trombocitopênica, síndrome pós-cardiotomia e pós-infarto do } \\
\text { miocárdio, dentre outras. }\end{array}$ \\
\hline Doenças de órgãos adjacentes \\
\hline $\begin{array}{l}\text { Miocardites, infarto do miocárdio, dissecção aórtica, infarto pulmonar, } \\
\text { pneumonia, empiema, doenças do esôfago, hidropericárdio na IC, } \\
\text { síndromes paraneoplásicas. }\end{array}$ \\
\hline Doenças metabólicas \\
\hline $\begin{array}{c}\text { Insuficiência renal (uremia), diálise, mixedema, doença de Addison, } \\
\text { cetoacidose diabética. }\end{array}$ \\
\hline Doenças neoplásicas \\
\hline Primárias: mesotelioma, sarcoma, fibroma, lipoma e outros. \\
\hline $\begin{array}{l}\text { Secundárias: neoplasias de pulmão, mama, estômago e cólon, leucemia e } \\
\text { linfoma, melanoma, sarcoma, dentre outras. }\end{array}$ \\
\hline Trauma \\
\hline Direto: ferimento penetrante de tórax, perfuração de esôfago, corpo estranho. \\
\hline Indireto: trauma de tórax não penetrante, irradiação mediastinal. \\
\hline Outras situações ou síndromes \\
\hline $\begin{array}{l}\text { Síndromes de injúria pericárdica e miocárdica, doença inflamatória de Bowel, } \\
\text { síndrome de Loffler, sindrome de Stevens-Johnson, aortite de células gigantes, } \\
\text { síndrome eosinofilica, pancreatite aguda, gravidez, dentre outras. }\end{array}$ \\
\hline Idiopática \\
\hline
\end{tabular}

\section{Diagnóstico clínico}

\subsection{Pericardite aguda}

A pericardite aguda classicamente se manifesta como uma síndrome febril com frequente acometimento de vias aéreas superiores, dor torácica e atrito pericárdico. A dor torácica pode variar com a respiração ou posição do tórax, variando também de intensidade e duração. $\mathrm{O}$ atrito pericárdico pode 
compreender de um a três tempos e pode ser transitório. Podemos ter acometimento pleural, associado à presença de derrame ou atrito pleural. Por vezes, a pericardite encontra-se associada a miocardite, que deve ser suspeitada na presença de exame clínico de disfunção ventricular aguda.

Os marcadores de alto risco da pericardite aguda são: elevação de enzimas de necrose miocárdica, febre acima de $38^{\circ} \mathrm{C}$ e leucocitose (elevada possibilidade de pericardite purulenta), derrames pericárdicos volumosos com ou sem tamponamento cardíaco, pacientes imunocomprometidos, história prévia de anticoagulação oral, disfunção global pelo ecocardiograma, sugerindo miopericardite. Esses marcadores indicam a necessidade de admissão hospitalar, intensificação da avaliação etiológica e otimização terapêutica ${ }^{173,174}$.

Abaixo, o fluxograma de avaliação admissional na pericardite (figura 3).

\subsection{Tamponamento cardíaco}

O saco pericárdico contém uma pequena quantidade de líquido (30 a $50 \mathrm{ml}$ ) que envolve o coração. Quando uma quantidade significativa de líquido se acumula e ultrapassa a capacidade de distensão do tecido fibroelástico pericárdico, ocorre progressiva compressão de todas as câmaras cardíacas decorrente do aumento da pressão intrapericárdica, redução do volume de enchimento cardíaco e maior interdependência ventricular ${ }^{175}$

O desenvolvimento do tamponamento depende da velocidade de instalação e do fator causal: o tamponamento cardíaco agudo ocorre em minutos, devido ao trauma, ruptura do coração e aorta, ou como complicação de procedimentos diagnósticos e terapêuticos (biópsias cardíacas, estudo eletrofisiológico, oclusão de apêndice atrial, oclusores de septo interatrial etc.), resultando num quadro de choque. Já o tamponamento cardíaco subagudo ocorre entre dias

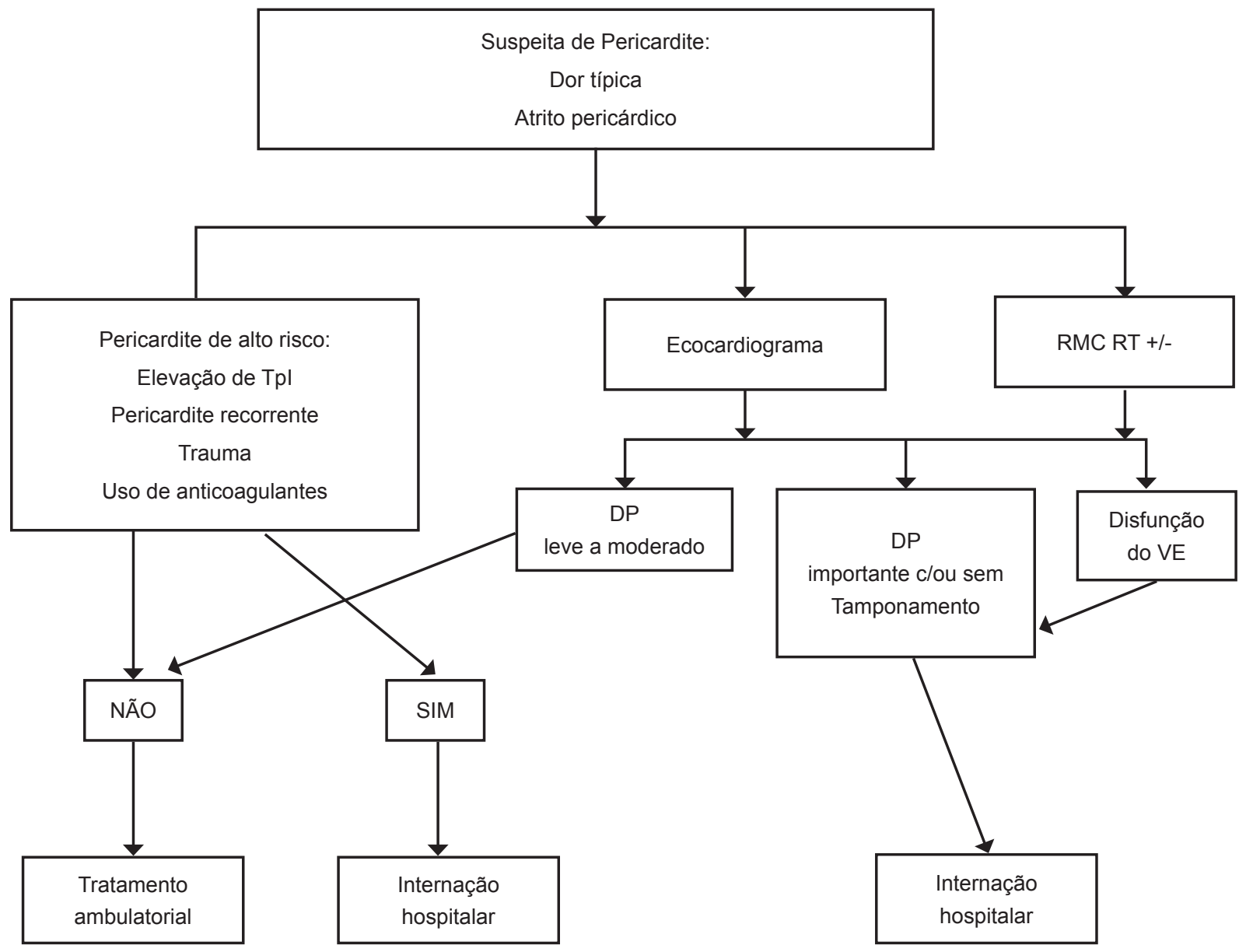

DP: Derrame Periocárdico; RMC: Ressonância Magnética Cardíaca; AINH: anti-inflamatório não hormonal; RT: Realce Tardio; Tpl: Tropomina I.

Figura 3 - Fluxograma de conduta admissional das pericardites. 
e semanas e poder estar associado com dispneia e fadiga. Tamponamento de baixa pressão (oculto) ocorre em pacientes que estão hipovolêmicos, com consequente redução da pressão intracardíaca, favorecendo a compressão extrínseca do derrame pericárdico. Tamponamento cardíaco regional ocorre quando um derrame localizado ou um hematoma produz compressão regional em uma única câmara ${ }^{168}$.

O diagnóstico é clínico, baseado na história e no exame físico: taquicardia, pressão venosa elevada, hipotensão arterial e a presença de pulso arterial paradoxal.

\subsection{Pericardite Constritiva}

A pericardite constritiva frequentemente está associada a um paciente sintomático com dispneia de esforço e/ou fadiga associada a disfunção diastólica e presença de ascite desproporcional ao edema de membros inferiores. No pulso venoso jugular observamos colapso " $Y$ " proeminente e sinal de Kussmaul. No pulso arterial podemos encontrar a presença de pulso paradoxal em um terço dos casos.

Formas transitórias de pericardites efusivas constritivas (constrição sem importante espessamento do pericárdio parietal, geralmente associada a derrame) podem acontecer no contexto da pericardite aguda, frequentemente associada a tuberculose, neoplasias malignas e hemopericárdio.

\subsection{Marcadores laboratoriais}

\subsubsection{Marcadores de atividade de doença}

\section{a) Marcadores de necrose miocárdica:}

Níveis elevados de marcadores miocárdicos são observados em pacientes com pericardite aguda, sendo mais frequente a elevação de troponina I (Tnl) do que de CKMB, uma vez que esta pode estar elevada em decorrência da miosite periférica por infecções virais ${ }^{176,177}$. Estudo retrospectivo avaliou 55 pacientes com pericardite aguda e observou elevação de Tnl em $27 \%$ dos $\operatorname{casos}^{178}$. Estudo pequeno sugere que o pico de Tnl em geral ocorre no segundo dia após início dos sintomas e seus níveis permanecem elevados por tempo mais prolongado do que os de $\mathrm{CKMB}^{177}$. A elevação da Tnl é marcador de comprometimento miocárdico associado (miopericardite).

\section{b) Marcadores de atividade inflamatória:}

Os marcadores de atividade inflamatória de fase aguda como VHS, leucocitose e Proteína C reativa (PCR), encontram-se elevados em aproximadamente 75\% dos pacientes, sendo que a ausência desses marcadores na avaliação inicial de pacientes e não afasta o diagnóstico, principalmente nos que estão em uso de anti-inflamatórios não hormonais ou com comprometimento imunológico. Estes tendem a normalizar ao fim de duas semanas, sendo que valores persistentemente elevados indicam a necessidade de terapêutica anti-inflamatória prolongada e maior risco de recorrência da pericardite ${ }^{179}$. A dosagem seriada de PCR é útil para o diagnóstico e avaliação de resposta ao tratamento da pericardite aguda.

\section{c) BNP / NT-proBNP:}

Os níveis de peptídeo natriurético atrial do tipo B (BNP) e da fração N-terminal do BNP (NT-proBNP) podem estar elevados em doenças pericárdicas ${ }^{180,181}$. No entanto, não há evidências suficientes que justifiquem seu uso rotineiro para o diagnóstico de pericardite aguda.

\subsubsection{Marcadores do diagnóstico etiológico}

A avaliação sorológica em busca de um fator causal deve incluir dosagem de hormônios tireoidianos; provas reumatológicas; função renal; hemoculturas, na suspeita de infecção bacteriana. A pesquisa viral através de sorologia em sangue não deve ser realizada, pois não possui correlação com os achados no pericárdio. Na presença de derrame pericárdico volumoso, a análise histológica e imuno-histoquímica do pericárdio e do líquido pericárdico para avaliação de tuberculose (dosagem de adenosina deaminase), neoplasia, pesquisa viral e de outros fatores pode aumentar a chance de diagnóstico etiológico de forma significativa ${ }^{182}$. Na pericardite aguda idiopática recorrente, a presença de autoanticorpos antinúcleo em baixos títulos é comum e sugere uma possível patogênese autoimune ${ }^{183}$.

A tabela 22 resume as principais indicações para marcadores laboratoriais na pericardite.

Tabela 22 - Indicações de marcadores laboratoriais na pericardite.

\begin{tabular}{ccc}
\hline $\begin{array}{c}\text { Classe de } \\
\text { recomendação }\end{array}$ & Indicações & $\begin{array}{c}\text { Nível de } \\
\text { evidência }\end{array}$ \\
\hline Classe I & $\begin{array}{c}\text { Dosagem de PCR para diagnóstico e } \\
\text { seguimento de pericardite aguda. }\end{array}$ & B \\
\hline Classe I & $\begin{array}{c}\text { Dosagem de hormônios tireoidianos, } \\
\text { autoanticorpos e avaliação de função } \\
\text { renal na investigação etiológica de } \\
\text { pericardite aguda. }\end{array}$ & C \\
\hline Classe Ila & $\begin{array}{c}\text { Dosagem de troponina para diagnóstico } \\
\text { de pericardite aguda. }\end{array}$ & C \\
\hline Classe IIb & $\begin{array}{c}\text { Dosagem de CKMB para diagnóstico de } \\
\text { pericardite aguda. }\end{array}$ & $\mathrm{C}$ \\
\hline Classe IIb & $\begin{array}{c}\text { Dosagem de BNP/NTproBNP para auxiliar } \\
\text { no diagnóstico diferencial entre pericardite } \\
\text { constritiva e cardiomiopatia restritiva. }\end{array}$ & $\mathrm{C}$ \\
\hline Classe III & $\begin{array}{l}\text { Dosagem de BNP/NTproBNP para } \\
\text { diagnóstico de pericardite aguda. }\end{array}$ & $\mathrm{C}$ \\
\hline
\end{tabular}

\subsection{Eletrocardiograma}

As alterações eletrocardiográficas da pericardite são bastante amplas (tabela 23) e acontecem nos segmentos PR, segmento ST e no ritmo, variando de acordo com a fase da pericardite. O ECG pode ser normal em até $6 \%$ dos $\operatorname{casos}^{184}$.

$\mathrm{Na}$ pericardite aguda, as alterações eletrocardiográficas acontecem em quatro estágios ${ }^{185}$. São eles:

Estágio I: supradesnível do segmento ST côncavo e difuso, exceto em aVR e V1, aonde ocorre infradesnível; onda T apiculada, com leve aumento da amplitude; infradesnível do segmento PR (exceto em aVR, aonde ocorre supradesnível). Essas alterações acontecem em mais de $80 \%$ dos $\operatorname{casos}^{186,187}$.

Estágio II: normalização do segmento ST e PR, além do achatamento da onda T. 
Estágio III: inversão da onda T difusa, simulando isquemia miocárdica.

Estágio IV: Retorno à normalidade da onda T. Pode ocorrer semanas ou meses após o evento inicial.

Alterações do ritmo podem ocorrer em qualquer estágio e variam de taquicardia sinusal até arritmias atriais diversas ${ }^{188}$.

Baixa amplitude do QRS acontece na presença de derrame pericárdico, que melhora após pericardiocentese $\mathrm{e}^{189,190}$. A alternância na morfologia ou amplitude do QRS está associada à pericardite com derrame pericárdico volumoso e sinais de tamponamento cardíaco ${ }^{191}$.

Os principais diagnósticos diferenciais das alterações eletrocardiográficas são infarto agudo do miocárdio, tromboembolismo pulmonar, áreas discinéticas e repolarização precoce $^{192}$.

A diferenciação da pericardite com repolarização precoce pode ser feita através da razão entre a amplitude do início do ST sobre a amplitude da onda T (ST/T) em V6. O diagnóstico de pericardite ocorre quando a razão ST/T é igual ou maior que $0,25{ }^{193}$.

Na pericardite crônica observam-se predominantemente ondas T invertidas e baixa amplitude do QRS ${ }^{194}$.

Tabela 23 - Recomendações de angiotomografia de coronárias na avaliação de miocardite.

\begin{tabular}{ccc}
\hline $\begin{array}{c}\text { Classe de } \\
\text { recomendação }\end{array}$ & Indicação & $\begin{array}{c}\text { Nível de } \\
\text { evidência }\end{array}$ \\
\hline Classe I & $\begin{array}{c}\text { Eletrocardiograma para diagnóstico de } \\
\text { pericardite aguda. }\end{array}$ & $\mathrm{C}$ \\
\hline
\end{tabular}

\subsection{Radiografia}

Na pericardite aguda, a radiografia de tórax é normal na maioria das vezes. A presença de cardiomegalia ocorre apenas quando há mais de $200 \mathrm{ml}$ de fluido no saco pericárdico. O aumento progressivo do derrame pericárdico, que ocorre, por exemplo, no tamponamento cardíaco, resulta em formato globular da silhueta cardíaca à radiografia de tórax ${ }^{195}$.

Estudos mostram que o aumento da silhueta cardíaca à radiografia de tórax tem sensibilidade moderada (70\%), porém baixa especificidade (41\%) para o diagnóstico de derrame pericárdico. Não há estudos que avaliam a sensibilidade e especificidade do método para o diagnóstico de pericardite, mas considerando que a pericardite pode não ser acompanhada por derrame pericárdico em grande parte das vezes e que não há outras alterações específicas desta patologia, não é possível definir pericardite com base apenas em dados radiológicos ${ }^{196}$.

A presença de calcificação do pericárdio, que pode ser evidenciada facilmente pela radiografia de tórax, sugere fortemente pericardite constritiva em pacientes com insuficiência cardíaca. No entanto, está presente em apenas $25 \%$ dos pacientes com pericardite constritiva (tabela 24) ${ }^{197}$.
Tabela 24 - Indicação de radiografia de tórax nas afecções pericárdicas.

\begin{tabular}{ccc}
\hline $\begin{array}{c}\text { Classe de } \\
\text { recomendação }\end{array}$ & Indicação & $\begin{array}{c}\text { Nível de } \\
\text { evidência }\end{array}$ \\
\hline Classe I & $\begin{array}{c}\text { Radiografia de tórax como } \\
\text { complementação diagnóstica } \\
\text { na suspeita clínica de afecções } \\
\text { pericárdicas. }\end{array}$ & C \\
\hline
\end{tabular}

\subsection{Ecocardiograma}

A ecocardiografia tem se mostrado uma ferramenta muito útil no diagnóstico das doenças do pericárdio, assim como no acompanhamento da resposta terapêutica e do prognóstico. Também tem sido utilizada como guia na drenagem do derrame pericárdico.

Comumente, os achados ao ecocardiograma associados a pericardite aguda envolvem aumento do espessamento pericárdico e derrame pericárdico. No entanto, podemos ter casos de pericardite aguda sem alterações ao ecocardiograma, usualmente denominados "pericardite aguda seca".

\subsubsection{Derrame pericárdico}

A ecocardiografia bidimensional permite a avaliação semiquantitativa do derrame pericárdico e de sua repercussão hemodinâmica. Em geral, quando o tamanho do derrame ao modo $\mathrm{M}$ é $<10 \mathrm{~mm}$ e é visualizado apenas na parte posterior ao ventrículo esquerdo, trata-se de um derrame pequeno. Quando mede entre 10 e $20 \mathrm{~mm}$ e circunda todo o coração, é moderado. Finalmente, espaços livres de eco > 20 $\mathrm{mm}$ caracterizam derrame importante ${ }^{198}$. Derrames pequenos geralmente só são vistos posteriores ao ventrículo esquerdo, enquanto os que são suficientemente grandes para causar tamponamento cardíaco geralmente são vistos circundando todo o coração. O ecocardiograma pode oferecer informações sobre a etiologia, pois permite caracterizar a natureza do líquido (se transudato ou exsudato), verificar se existe fibrina (como na tuberculose), cálcio, coágulos, massas sugestivas de tumor ou cisto, permitindo portanto inferências sobre o diagnóstico etiológico.

O pericárdio deve ser avaliado em todos os cortes possíveis. $\mathrm{Na}$ suspeita de pericardite constritiva, a espessura do pericárdio deve ser medida (espessura > 3 mm ao ETE 95\% de sensibilidade e $86 \%$ de especificidade para pericárdio espessado).

\subsubsection{Tamponamento cardíaco}

Os achados ecocardiográficos usuais na presença de síndrome clínica de tamponamento são: dilatação das cavas com pouca variação respiratória, colapso diastólico da parede livre do ventrículo direito, do átrio direito, do átrio esquerdo e raramente do ventrículo esquerdo. O colapso do AD é um sinal mais sensível de tamponamento, ao passo que o do VD, quando dura mais de $1 / 3$ da diástole, é mais específico. Ao Doppler podemos observar aumento do fluxo tricúspide e redução do fluxo mitral na inspiração, e na expiração, um aumento no fluxo mitral de até $25 \%$ e redução do tricúspide. Os achados ao Doppler ecocardiograma nada mais são do que a expressão ecocardiográfica do pulso paradoxal. 


\section{Diretrizes}

\subsubsection{Pericardite constritiva}

De uma forma geral, $80 \%$ dos casos podem registrar espessamento pericárdico. Porém, como este nem sempre pode ser detectado pela ecocardiografia, mesmo que pelo ETE, outros métodos diagnósticos, como ressonância ou tomografia computadorizada, podem ser indicados.

Os achados usuais na presença de constrição pericárdica são: movimentação anormal do septo interventricular, aumento moderado biatrial do fluxo restritivo, variação respiratória maior que $25 \%$ na velocidade do fluxo mitral. Essa variação não é patognomônica da pericardite, já que também ocorre nas doenças respiratórias (doença pulmonar obstrutiva crônica). Nestas, contudo, ocorre grande variação respiratória do fluxo da veia cava superior, que na pericardite é menor.

Outro achado útil para o diagnóstico de pericardite constritiva, especialmente no seu diagnóstico diferencial das síndromes restritivas, é a presença de velocidade normal da onda e' ao Doppler tecidual (> $8 \mathrm{~cm} / \mathrm{seg}$ ), o que não ocorre nas cardiopatias restritivas. É importante destacar: na presença de doenças do pericárdio, deve ser usada a onda e' septal, e não a lateral, devido à possível influência do espessamento/ derrame pericárdico na parede livre do VE. Além disso, a calcificação do anel mitral pode levar à diminuição da onda $\mathrm{e}^{\prime}$ septal $^{199}$. A relação linear que existe entre o índice $E / E^{\prime}$ e a pressão atrial esquerda, que é útil para se avaliar as pressões de enchimento nas cardiomiopatias, é invertida (paradoxo anular) na pericardite constritiva. Não se observa aumento do retorno venoso sistêmico com a inspiração.

As indicações da ecocardiografia transtorácica na pericardite encontram-se na tabela 25 .

Tabela 25 - Indicações de ecocardiograma na pericardite.

\begin{tabular}{ccc}
\hline $\begin{array}{c}\text { Classe de } \\
\text { recomendação }\end{array}$ & Indicações & $\begin{array}{c}\text { Nível de } \\
\text { evidência }\end{array}$ \\
\hline Classe I & $\begin{array}{c}\text { Ecodopplercardiograma para o } \\
\text { diagnóstico de afecções pericárdicas. }\end{array}$ & B \\
\hline Classe I & $\begin{array}{c}\text { Ecodopplercardiograma para a } \\
\text { monitoração da pericardiocentese nas } \\
\text { afecções pericárdicas. }\end{array}$ & B \\
\hline Classe I & $\begin{array}{c}\text { Ecodopplercardiograma para o } \\
\text { acompanhamento de afecções } \\
\text { pericárdicas. }\end{array}$ & C \\
\hline
\end{tabular}

\subsection{Tomografia computadorizada do coração (TCC)}

Na pericardite aguda, a TCC pode encontrar pericárdio uniformemente espessado, derrame pericárdico e algum realce precoce após contraste venoso. O derrame pericárdico pode ser loculado, com septações, e eventualmente a presença de gás é associada à presença de microrganismos. Os septos formados também captam contraste. A densidade do derrame deve ser observada, pois transudatos têm baixa densidade (0-10 UH), ao contrário de exsudatos, hemorragias e neoplasias ${ }^{200}$.

Na pericardite constritiva a TCC identifica espessamento pericárdico, calcificações pericárdicas, ou ambos ${ }^{201}$. A espessura normal do pericárdio mede menos que $2 \mathrm{~mm}$, e só é identificada adequadamente quando há gordura envolvendo-o. O espessamento pode envolver todo ou quase todo o pericárdio ou ser localizado ${ }^{202,203}$. A constrição cardíaca causada pelo espessamento do pericárdio dá ao coração uma forma estreita tubular. Se a constrição predominar na fossa atrioventricular, forma-se uma cintura. Há distensão dos átrios e das veias cavas. Derrame pericárdico e ascite também podem ser achados.

Na pericardite neoplásica, além de derrame pericárdico e espessamento dos folhetos, pode ser identificável a presença de massas no pericárdio ou a infiltração de tecidos adjacentes, comprometimento das bordas ventriculares, septos espessados e captantes de contraste.

A tabela 26 resume as principais indicações da TCC na pericardite.

Tabela 26 - Indicações da TCC na pericardite.

\begin{tabular}{ccc}
\hline $\begin{array}{c}\text { Classe de } \\
\text { recomendação }\end{array}$ & Indicações & $\begin{array}{c}\text { Nível de } \\
\text { evidência }\end{array}$ \\
\hline Classe Ila & $\begin{array}{c}\text { Pericardite aguda (apresentação aguda } \\
\text { tipo infarto ou associada a quadro viral } \\
\text { agudo ou subagudo; }<3 \text { meses) }\end{array}$ & B \\
\hline Classe Ila & Pericardite crônica > 3 meses & C \\
\hline Classe lla & $\begin{array}{c}\text { Pericardite constritiva com suspeita de } \\
\text { calcificação pericárdica associada }\end{array}$ & B \\
\hline Classe Ilb & $\begin{array}{c}\text { Pericardite constritiva sem suspeita de } \\
\text { calcificação pericárdica associada }\end{array}$ & $\mathrm{C}$ \\
\hline
\end{tabular}

\subsection{Ressonância magnética (RMC)}

A RMC está indicada na avaliação diagnóstica das pericardites aguda e crônica (Tabela 27). Ela permite quantificar o grau de espessamento pericárdico e o volume do derrame pericárdico, e se distingue por permitir a identificação dos sinais sugestivos de injúria inflamatória miopericárdica através da técnica do realce tardio ${ }^{168}$.

\section{Tabela 27 - Indicações da RMC na pericardite.}

\begin{tabular}{ccc}
\hline $\begin{array}{c}\text { Classe de } \\
\text { recomendação }\end{array}$ & Indicações & $\begin{array}{c}\text { Nível de } \\
\text { evidência }\end{array}$ \\
\hline Classe lla & $\begin{array}{c}\text { Pericardite Aguda (apresentação aguda } \\
\text { tipo infarto ou associada a quadro viral } \\
\text { agudo ou sub-agudo; < 3 meses) }\end{array}$ & B \\
\hline Classe lla & Pericardite Crônica > 3 meses & B \\
\hline Classe lla & $\begin{array}{c}\text { Pericardite Constrictiva sem suspeita de } \\
\text { calcificação pericárdica associada }\end{array}$ & B \\
\hline Classe lla & $\begin{array}{c}\text { Pericardite Constrictiva com suspeita de } \\
\text { calcificação pericárdica associada }\end{array}$ & C \\
\hline
\end{tabular}

\subsection{Medicina Nuclear}

Entre as principais aplicações da medicina nuclear no diagnóstico não invasivo das pericardites devemos destacar: (1) diagnóstico diferencial em pacientes atendidos com dor torácica e alterações eletrocardiográficas sem curva enzimática características, em especial na ausência de RMC disponível ou em pacientes com contraindicações à RMC; (2) diagnóstico de pericardite por BK em atividade (novas evidências têm apontado 
para uso de PET com FDG); (3) diagnóstico de pericardite em pacientes com doenças sistêmicas como meningite, sepse pneumocócica, artrite reumatoide, lúpus; (4) acompanhamento de pacientes com pericardite induzida por quimioterápicos ou radioterapia; e (5) suspeita clínica de pericardite em que há indefinição diagnóstica após investigação com ecocardiograma e RMC 204,205 .

\subsection{Pericardiocentese e biópsia pericárdica}

A pericardiocentese é um procedimento invasivo utilizado com objetivo terapêutico e diagnóstico. Ela está indicada na presença de quadro clínico de tamponamento pericárdico, como medida terapêutica salvadora. ${ }^{168,195} \mathrm{~A}$ pericardiocentese também está indicada na suspeita clínica de hemopericárdio pós trauma, pericardite bacteriana ou neoplásica (tabela 28) ${ }^{206}$.

Nos derrames pericárdicos importantes assintomáticos (mais de $20 \mathrm{~mm}$ ao ecocardiograma na diástole), a pericardiocentese está indicada para avaliação diagnóstica e pela possibilidade de evolução para tamponamento pericárdico de forma súbita ${ }^{207}$.

A pericardiocentese pode ser feita à beira do leito do paciente sob anestesia local ou na hemodinâmica com radioscopia. A via de acesso pode ser transtorácica, mediana ou subxifoide. $\mathrm{O}$ acesso pela via subxifoide permite uma exposição limitada do pericárdio, resultando em baixo índice de positividade ${ }^{208}$. A agulha para punção pericárdica deve ser guiada por monitorização eletrocardiográfica ou por método de imagem. A pericardiocentese guiada pelo ecocardiograma apresenta menor risco de complicações e maior sucesso. Além disso, a injeção salina permite a localização da agulha durante o procedimento ${ }^{209}$. Após a introdução do cateter é importante a aferição da pressão da cavidade pericárdica seguida da aspiração do seu líquido. $\mathrm{O}$ alívio dos sintomas deve ser imediato.

Nos casos de pericardite-efusivo-constritiva, há a persistência da elevação da pressão atrial direita após redução da pressão intrapericárdica para níveis normais após drenagem do derrame pericárdico ${ }^{210}$. O líquido pericárdico deve ser encaminhado para análise citológica, cultura, pesquisa de células neoplásicas pesquisa viral por PCR, dosagem de adenosina deaminase, de acordo com a suspeita etiológica: viral, bacteriana, tuberculosa, fúngica, neoplásica. A contraindicação absoluta é a dissecção aórtica e as relativas são: coagulopatia, anticoagulação, trombocitemia menor que $50.000 / \mathrm{mm}^{3}$, derrame pequeno, posterior ou loculado.

Com a finalidade de aumentar a sensibilidade diagnóstica, novas estratégicas diagnósticas e terapêuticas surgiram, como a vídeopericardioscopia que permite ampla ressecção do pericárdio e maior exposição da cavidade pericárdica ${ }^{211}$.

A biópsia pericárdica, por sua vez, está indicada na investigação diagnóstica em pacientes com pericardite persistente refratária ao tratamento clínico, sem diagnóstico definitivo estabelecido. A biópsia pode ser coadjuvante na drenagem pericárdica terapêutica para o tamponamento pericárdico recidivante ou em derrames volumosos associados à importantes sintomas clínicos.

A biópsia pericárdica também pode ser realizada através de pericardioscopia, que pode, guiar o local para retirada dos fragmentos ${ }^{212,213}$. Essa técnica tem demonstrado ser de grande auxílio na melhora da acurácia diagnóstica da pericardite por doença neoplásica, como também na suspeita de tuberculose ou infecção bacteriana ${ }^{214,215}$.

A presença de derrame pericárdico favorece a realização da biópsia por pericardioscopia e sua capacidade diagnóstica, em comparação com as pericardites sem derrame pericárdico associado. Os tecidos obtidos pela biópsia devem ser submetidos a análise histológica (2 fragmentos) e imunohistoquímica (2 fragmentos), além de a pesquisa viral através da reação em cadeia da polimerase viral (4 a 6 fragmentos), que demonstra maior capacidade de detecção viral que a pesquisa no líquido pericárdico ${ }^{216-218}$.

Na figura 4 observamos o fluxograma de abordagem no derrame pericárdico com as indicações de pericardiocentese e biópsia pericárdica.

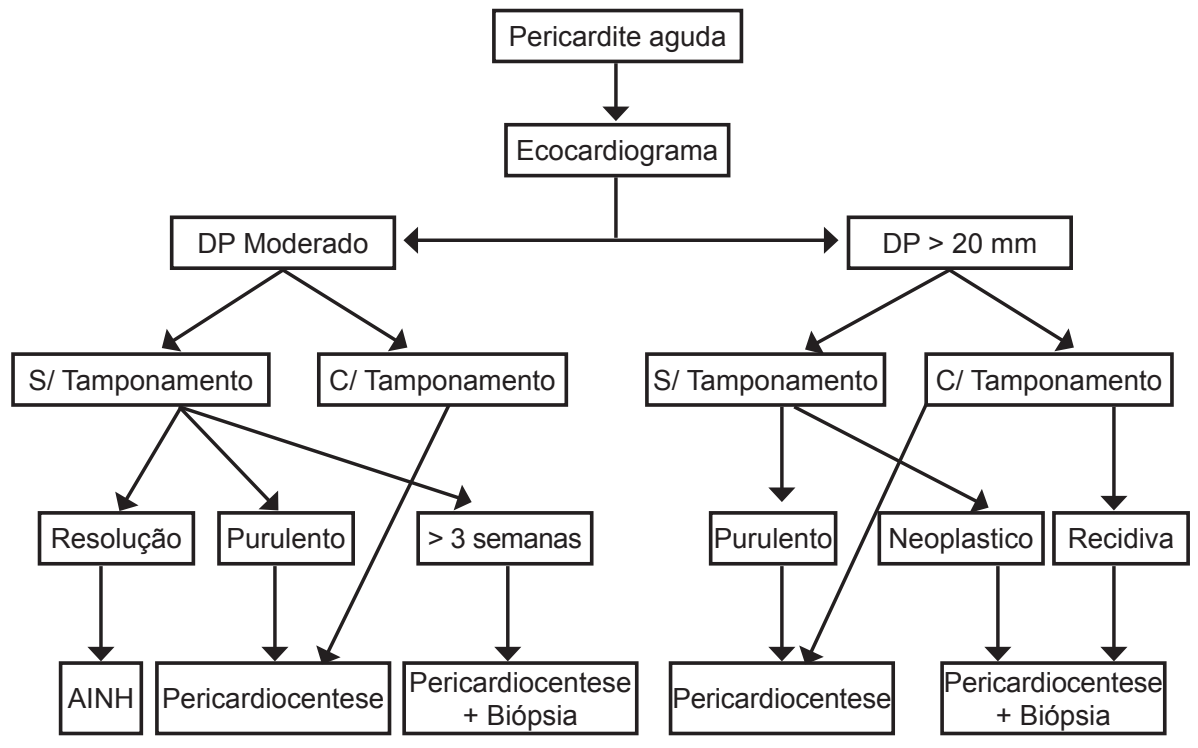

DP: Derrame pericárdico; AINH; Anti-inflamatório não hormonal.

Figura 4 - Fluxograma de indicação de pericardiocentese e biópsia pericárdica. 


\section{Diretrizes}

Tabela 28 - Indicações de pericardiocentese com biopsia pericárdica.

\begin{tabular}{ccc}
\hline $\begin{array}{c}\text { Classe de } \\
\text { recomendação }\end{array}$ & Indicações & $\begin{array}{c}\text { Nível de } \\
\text { evidência }\end{array}$ \\
\hline Classe I & $\begin{array}{c}\text { Na suspeita de tuberculose, neoplasia ou } \\
\text { etiologia bacteriana ou fúngica }\end{array}$ & B \\
\hline Classe I & $\begin{array}{c}\text { Associada à videopericardioscopia para } \\
\text { aumentar a sensibilidade diagnóstica }\end{array}$ & B \\
\hline Classe lla & $\begin{array}{c}\text { No diagnóstico de derrames pericárdicos } \\
\text { importantes assintomáticos }\end{array}$ & B \\
\hline
\end{tabular}

\subsection{Análise histológica}

O quadro histológico pode ser agrupado segundo categorias etiológicas, sendo a etiologia da tuberculose a mais frequente. Acredita-se que alguns vírus causem pericardite autolimitada. Quando a inflamação é acentuada, existe proliferação exuberante de células mesoteliais reativas com atipias nucleares que impõem o diagnóstico diferencial com infiltração neoplásica. Para essa finalidade, a imunohistoquímica é útil, pois contém a diferenciação por marcadores de células epiteliais e mesoteliais $^{212,219}$.

Pericardite fibrinosa - graus variados de espessamento por edema, discreto infiltrado inflamatório e fibrina na superfície, com espessamento do colágeno e tecido de granulação nos casos mais crônicos. Por vezes há proliferação exuberante de células mesoteliais.

Pericardite fibrino-purulenta - infiltrado neutrofílico, por vezes formando abscessos, em meio a fibrina e restos celulares na superfície serosa. O encontro do agente etiológico é frequente.

Pericardite crônica inespecífica - infiltrado linfo-histiocitário associado a fibrose de grau variável. Acredita-se que pode estar associada a infecção viral.

Pericardite hemorrágica - encontrada em associação com pericardites agudas, é acompanhada de componente hemorrágico expressivo. As principais causas são: tuberculose, infiltração neoplásica e cirurgia cardíaca.

Pericardite granulomatosa - o principal agente causal é a tuberculose, mas também micobactérias atípicas e fungos como histoplasma e cândida. Na tuberculose é comum necrose caseosa, e pode evoluir para pericardite constritiva.

Pericardite constritiva - é o resultado da cicatrização de uma pericardite prévia. Caracteriza-se por espessamento fibroso acentuado e aderências entre os folhetos visceral e parietal. Às vezes coexiste calcificação extensa ou em placas.

Pericardite pós-infarto do miocárdio e síndrome de Dressler admite-se que a vizinhança com o miocárdio necrótico possa causar inflamação do pericárdio pós-infarto do miocárdio, que quando ocorre tardiamente é denominado de síndrome de Dressler. A histologia é uma pericardite crônica inespecífica.

A tabela 29 resume as indicações para da imunohistoquímica para o diagnóstico de pericardite.
Tabela 29 - Indicação de imuno-histoquímica para o diagnóstico de pericardite.

\begin{tabular}{ccc}
\hline $\begin{array}{c}\text { Classe de } \\
\text { recomendação }\end{array}$ & Indicações & $\begin{array}{c}\text { Nível de } \\
\text { evidência }\end{array}$ \\
\hline Classe Ila & $\begin{array}{c}\text { Imuno-histoquímica com HLADR tipo I e II } \\
\text { na investigação diagnóstica de inflamação } \\
\text { epimiocárdica e pericárdica. }\end{array}$ & B \\
\hline Classe lla & $\begin{array}{c}\text { Imuno-histoquímica para pesquisa e } \\
\text { contagem de infiltrado por linfócitos T, B e } \\
\text { macrófagos epimiocárdica e pericárdica. }\end{array}$ & B \\
\hline
\end{tabular}

\section{Tratamento}

A hospitalização é desejável na maioria dos pacientes para determinação da etiologia - observar sinais ou sintomas de tamponamento e iniciar com anti-inflamatórios não hormonais (AINH) e tratamento sintomático. AINH são a droga principal para o início do tratamento. Ibuprofeno é preferido, com raros efeitos colaterais e efeitos favoráveis no fluxo coronariano em altas doses.

O tratamento com corticosteroides sistêmicos deve ser restrito a doenças do tecido conjuntivo, doenças autoimunes ou pericardite urêmica. A aplicação intrapericárdica de corticosteroides evita efeitos colaterais sistêmicos e é altamente efetiva para retirar prednisona, ibuprofeno ou colchicina ${ }^{220,221}$, e devem ser introduzidos precocemente. Pacientes em recuperação devem ser observados para possível recorrência ou constrição.

Se o paciente necessitar de anticoagulantes, a heparina é recomendada com observação estrita.

\subsection{Anti-inflamatórios não hormonais e colchicina}

Os AINH são os principais medicamentos para o tratamento das pericardites idiopática e viral. O objetivo principal do tratamento é o alívio da dor e a resolução do processo inflamatório ${ }^{222,223}$.

Os AINH devem ser utilizados nas doses anti-inflamatórias: ácido acetil salicílico (AAS), 500 a 750mg a cada 6 ou 8 horas, por 7 a 10 dias, seguido de redução gradual de $500 \mathrm{mg}$ por semana, por três semanas; ibuprofeno, 400 a $800 \mathrm{mg}$ a cada 6 ou 8 horas, por 14 dias; indometacina, 75 a 150 mg ao dia. Na pericardite pós-infarto agudo do miocárdio, deve-se evitar o uso de indometacina, por estar relacionada à redução do processo cicatricial da área infartada 224,225 .

O tempo de tratamento da pericardite com AINH é em torno de 14 dias, usualmente, podendo ser guiado pelos níveis séricos da PCRT como marcador de atividade inflamatória. A retirada dos AINH deve ser progressiva e lenta para reduzir a possibilidade de recorrência ${ }^{26}$. Todos os pacientes devem fazer uso de inibidores de prótons para proteção da mucosa gástrica.

A colchicina tem demonstrado ser efetiva como terapêutica coadjuvante da pericardite aguda, no alívio da dor e na prevenção da recorrência ao fim de dezoito meses 220,227 . A dose é de 0,5 mg de 12/12 horas ou 0,5 mg a cada 24 horas nos pacientes com menos de $70 \mathrm{~kg}$, pelo período de três meses no primeiro evento e 6 meses na pericardite recorrente ${ }^{228,229}$. 
Nas formas mais graves e recorrentes, alguns estudos sugerem o uso da colchicina por 12 a 24 meses após o último evento de recorrência com retirada gradual ${ }^{230,231}$.

O principal efeito adverso da colchinha é a diarreia que acomete cerca de $8 \%$ dos pacientes, e, com menos frequência, hepatotoxidade, miotoxidade e supressão da medula óssea. Assim, deve ser evitada em pacientes com insuficiência renal severa, disfunção hepática, discrasia sanguínea e distúrbios da motilidade gastrointestinal ${ }^{232-234}$.

\subsection{Imunossupressão}

A utilização de corticoides para supressão da atividade inflamatória da pericardite usualmente ocasiona dramática melhora clínica e inflamatória. Mas devem-se levar em consideração vários aspectos clínicos e fisiopatológicos que limitam a sua eficácia clínica como: 1) A terapia com corticoides favorece o desenvolvimento de recorrência por ocasionar o fenômeno de ancoramento imunológico; 2) Deve-se tentar definir o fator etiológico da pericardite para se ter uma previsão da resposta terapêutica, assim como de sua posologia; 3) Na suspeita de pericardite viral, devese pesquisar a presença viral através de análise do líquido pericárdico e por biópsia endopericárdica, para se afastar a presença viral antes da utilização do corticoide ${ }^{235}$.

A indicação da terapia com corticoide na pericardite aguda idiopática é para as situações de ausência de resposta terapêutica aos anti-inflamatórios não hormonais e à colchicina, ou quando a pericardite é secundária a doença autoimune, doença do tecido conectivo ou pericardite urêmica. A posologia recomendada é de $1 \mathrm{mg} / \mathrm{kg}$ de peso com duração de 2 a 4 semanas. Para se evitar o fenômeno de recorrência imunológica com reativação da pericardite, a retirada do corticoide deve ser lenta e deve-se se associar colchicina na dose de $1 \mathrm{mg}$ por dia ${ }^{168,228}$.

A utilização de corticosteroide intrapericárdico demonstrou importante melhora clínica e baixa recorrência de pericardite ao fim de um ano. A vantagem dessa forma de terapêutica é evitar os efeitos do uso do corticoide sistêmico e o desenvolvimento de recorrência. O esquema terapêutico é a infusão de triancinolona 300 mg/12-12h/dose única, associada ao uso de colchicina por 6 meses. Todos os pacientes foram submetidos a biópsia pericárdica e epimiocárdica, para comprovação do processo inflamatório e para se afastar a presença de infecção viral ou de outros agentes etiológicos. A limitação desse procedimento se deve ao seu caráter invasivo ${ }^{221,236}$.

$\mathrm{Na}$ pericardite recorrente o primeiro aspecto a ser analisado é a pesquisa do possível fator causal: 1) esquema terapêutico inadequado; 2) posologia inadequada; 3) uso de corticoide associado a uma retirada rápida; 4) reativação em decorrência a replicação viral por uso de corticóide; 5) reinfecção; 6) reativação de doença autoimune ou do tecido conectivo. Na ausência de um desses fatores, consideramos o uso de corticoide nos pacientes com crises frequentes e com importante comprometimento das condições clínicas; recomenda-se o uso de prednisona $1-1,5 \mathrm{mg} / \mathrm{kg}$, por 4 semanas com retirada lenta, de cerca de três meses. Em pacientes com recorrência frequente pode-se associar azatioprina na dose de 75-100mg/dia ou ciclofosfamida. Além disso, deve-se associar colchicina para redução da recorrência ${ }^{206,237}$.

A utilização de baixas doses de prednisona $(0,2$ a 0,5 mg/ $\mathrm{kg} / \mathrm{dia} / 4$ semanas) demonstrou a mesma eficácia terapêutica quando comparada a doses de $1 \mathrm{mg} / \mathrm{kg} /$ dia, mas com menor taxa de desenvolvimento de paraefeitos ${ }^{238}$.

\subsection{Antiviral}

As pericardites virais podem ser ocasionadas por diversos agentes virais. O diagnóstico é estabelecido através de pesquisa viral no tecido epimiocárdico, pericárdico e no líquido pericárdico. A terapêutica antiviral tem como objetivo não somente a melhora dos sintomas e a remissão da doença como também evitar a sua recorrência. Nas pericardites virais vários esquemas terapêuticos antivirais estão sendo testados: 1) pericardite por citomegalovírus: hiperimunoglobulina (4 ml/kg nos dia 0 , 4, e $8 ; 2 \mathrm{ml} / \mathrm{kg}$ nos dias 12 e 16; 2); Coxsackie B: interferon alfa (2.5 milhões IU/m2, s.c. por 3 semanas); 3) adenovírus e PVB-19: imunoglobulina intravenosa (10 g nos dias 1 e 3). Embora o uso da imunoglobulina siga o mesmo racional de utilização da miocardite viral, faltam estudos clínicos randomizados para definir a eficácia desta terapêutica ${ }^{239,240}$.

Tabela 30 - Indicações para terapêutica anti-inflamatória, imunossupressora e anti- viral na pericardite.

\begin{tabular}{|c|c|c|}
\hline $\begin{array}{l}\text { Classe de } \\
\text { recomendação }\end{array}$ & Indicações & $\begin{array}{l}\text { Nível de } \\
\text { evidência }\end{array}$ \\
\hline \multicolumn{3}{|c|}{ Anti-inflamatórios na pericardite aguda } \\
\hline Classe I & $\begin{array}{l}\text { Aspirina ou ibuprofeno por } 14 \text { dias no } \\
\text { tratamento da pericardite aguda }\end{array}$ & A \\
\hline Classe I & $\begin{array}{c}\text { Colchicina por } 3 \text { meses no tratmento } \\
\text { da pericardite aguda e } 6 \text { meses na } \\
\text { preicardite recorrente }\end{array}$ & $A$ \\
\hline \\
\hline Classe I & $\begin{array}{c}\text { Prednisona na ausência de resposta aos } \\
\text { AINH e à colchicina na ausência de inf } \\
\text { ecção viral ou outro agente etiológico, } \\
\text { comprovada por biopsia epimiocárdica e } \\
\text { pericárdica. }\end{array}$ & B \\
\hline Classe I & $\begin{array}{l}\text { Prednisona na ausência de infecção } \\
\text { viral ou outro agente etiológico, } \\
\text { comprovada por biópsia epimiocárdica } \\
\text { e pericárdica nas seguintes situações } \\
\text { clínicas: presença de pericardite } \\
\text { autoimune, doença do tecido conectivo } \\
\text { ou pericardite urêmica. }\end{array}$ & B \\
\hline Classe Ila & $\begin{array}{l}\text { Prednisona nos pacientes com pericardite } \\
\text { recorrente na ausência de fator causal } \\
\text { identificado ou infecção viral ou outro } \\
\text { agente etiológico, comprovada por biópsia } \\
\text { epimiocárdica e pericárdica. }\end{array}$ & C \\
\hline Classe lla & $\begin{array}{l}\text { Azatioprina nos pacientes com pericardite } \\
\text { recorrente apesar do uso da prednisona. }\end{array}$ & B \\
\hline Classe Illb & $\begin{array}{l}\text { Triancinolona intrapericárdica na pericardite } \\
\text { autorreativa na ausência de infecção viral } \\
\text { ou outro agente etiológico, comprovada por } \\
\text { biópsia epimiocárdica e pericárdica. }\end{array}$ & $\mathrm{B}$ \\
\hline \multicolumn{3}{|c|}{ Antivirais na pericardite aguda } \\
\hline Classe Ilb & Uso de imunoglobulina na pericardite viral & $\mathrm{C}$ \\
\hline
\end{tabular}




\section{Diretrizes}

\subsection{Tratamento no tamponamento cardíaco}

Esse tratamento é a drenagem do líquido pericárdico de forma a reduzir a pressão intrapericárdica e, dessa forma, melhorar a hemodinâmica do paciente. Na estabilização da hemodinâmica do paciente, anterior à drenagem pericárdica, pode-se fazer a infusão rápida de cristaloide com objetivo de melhorar a perfusão, e na presença de bradicardia indica-se a utilização de aminas ou atropina. A drenagem pericárdica pode ser realizada através de inserção de uma punção percutânea e colocação de um cateter de drenagem ou através drenagem cirúrgica aberta com ou sem pericardioctomia (janela pericárdica), ou ainda através de pericardioscopia assistida do vídeo ${ }^{241}$. A pericardiocentese por cateter deve ser guiada pela ecocardiografia, que permite a identificação do melhor local e ângulo de pressão, reduzindo as complicações e aumentando as taxas de sucesso ${ }^{242}$. A drenagem por cateter pode necessitar alguns dias e o cateter não deve ser removido até a drenagem ser inferior a 20-30 ml/24h.

A drenagem cirúrgica tem a vantagem de permitir a realização de biópsia pericárdica, sendo a forma recomendada em casos de recidiva do derrame após a drenagem via cateter e em casos de coágulos ou derrames localizados não acessíveis pela via percutânea ${ }^{197}$.

\subsection{Tratamento cirúrgico das afecções pericárdicas}

A síndrome de constrição pericárdica é tratada pela excisão do pericárdio. Por causa de aderências densas e calcificação que podem penetrar no miocárdio, a ressecção pericárdica pode ser um desafio técnico. Na maioria dos centros, o procedimento é feito através de esternotomia mediana, com a eventual necessidade do uso de circulação extracorpórea ${ }^{243}$. O objetivo do procedimento é liberar os ventrículos do pericárdio densamente aderido. Cuidado especial deve ser tomado ao dissecar nas regiões dos vasos coronarianos epicárdicos. O objetivo é ressecar o pericárdio de nervo frênico a nervo frênico, e também, posteriormente, em torno da entrada das veias cavas e veias pulmonares. A ressecção completa deve restaurar a curva de pressão-volume ${ }^{244}$. A ressecção completa do pericárdio, entretanto, não é viável em todos os casos, notadamente na pericardite constritiva induzida por radiação. A mortalidade operatória tem sido relatada tão alta quanto 10 a $20 \%{ }^{245,246}$. A sobrevida a longo prazo é menor em pacientes com cirurgia cardíaca prévia, e particularmente em pacientes com pericardite constritiva induzida por radiação ${ }^{247,248}$.

A tabela 31 resume as indicações do tratamento cirúrgico nas afecções pericárdicas.

Tabela 31 - Indicações do tratamento cirúrgico nas afecções pericárdicas.

\begin{tabular}{ccc}
\hline $\begin{array}{c}\text { Classe de } \\
\text { recomendação }\end{array}$ & Indicações & $\begin{array}{c}\text { Nível de } \\
\text { evidência }\end{array}$ \\
\hline Classe I & $\begin{array}{c}\text { Pericardiocentese ou drenagem } \\
\text { pericárdica aberta terapêutica em } \\
\text { pacientes com tamponamento cardíaco }\end{array}$ & $\mathrm{C}$ \\
\hline Classe I & $\begin{array}{c}\text { Pericardiectomia nos pacientes com } \\
\text { pericardite constritiva sintomáticos } \\
\text { refratários ao tratamento clínico. }\end{array}$ & $\mathrm{C}$ \\
\hline Classe lla & $\begin{array}{c}\text { Janela pericárdica em derrames } \\
\text { pericárdicos recorrentes. }\end{array}$ & $\mathrm{C}$ \\
\hline
\end{tabular}

\section{Situações especiais}

\subsection{Na doença renal crônica}

A doença renal crônica (DRC) grave é causa comum de doença pericárdica, incluindo pericardite e efusões pericárdicas. Múltiplos fatores contribuem para seu aparecimento, sendo em geral descritas de duas formas: urêmica e dialítica ${ }^{249}$.

A pericardite urêmica ocorre em torno de 10\% dos pacientes, antecedendo a diálise ou logo após o seu início ${ }^{250}$. Sua fisiopatologia é pouco conhecida e parece não ter relação com a causa base da DRC (exceto no LES e na esclerodermia), mas principalmente com os níveis de ureia. Costuma ter boa resolutividade com a continuidade da terapia dialítica (TD).

A pericardite associada à diálise ocorre em torno de 15\% dos pacientes em hemodiálise e mais raramente na diálise peritoneal. Está associada principalmente a hipervolemia e diálise inadequada. Por isso, a correção volêmica e adequação da TD são essenciais ${ }^{251}$.

As manifestações clínicas e laboratoriais são similares às observadas em pacientes não urêmicos com afecções pericárdicas semelhantes, exceto pela dor torácica, que costuma ocorrer menos nos pacientes com DRC terminal, e pelo eletrocardiograma não apresentar as alterações típicas da pericardite aguda, por ausência de inflamação miocárdica ${ }^{252,253}$

A maioria dos pacientes respondem prontamente à diálise, com resolução da pericardite em cerca de uma a duas semanas. No manuseio do quadro álgico e inflamatório, podem ser utilizados AINH e corticosteroides, sendo que demonstraram menor eficácia nos pacientes refratários à diálise. Nesses casos, o uso de colchicina tem demonstrado algum benefício ${ }^{255}$. Já o uso de heparina durante a TD deve ser controlado. Raramente a pericardite urêmica evolui para constrição pericárdica.

Os pacientesque evoluem com tamponamento pericárdico ou derrame pericárdico de volume persistente sintomático devem ser tratados com pericardiocentese, associada com instilação intrapericárdica de corticoide (triamcinolona 50 mg, 6-6 horas por 3 dias) ${ }^{256}$. A pericardiectomia está indicada na pericardite recorrente com dor persistente refratária ao tratamento anti-inflamatório ${ }^{257}$.

\subsection{Pós-pericardiotomia}

A síndrome pós-pericardiotomia (SPP) acomete em torno de 10 a $15 \%$ dos pacientes submetidos a trauma cirúrgico cardíaco, pericárdico ou ambos, ocorrendo após dias ou até meses $(80 \% \text { no primeiro mês })^{258}$. Acredita-se que a fisiopatologia seja mista com o trauma cirúrgico, gerando em primeiro momento inflamação e, na sequência, processo autoimune (anticorpos antissarcolemais cardíacos) ${ }^{259}$.

A grande maioria dos pacientes cursa com envolvimento pleuropericárdico, como febre após a primeira semana pós-operatória (sem evidência de infecção sistêmica ou focal), dor torácica pleurítica, efusão pleural nova ou piora de preexistente. Com menos frequência, pode apresentar atrito pericárdico (1/3 dos pacientes) e alterações eletrocardiográficas típicas ${ }^{260}$. A evolução para tamponamento 
pericárdico ou pericardite constritiva é menos comum, porém a SPP frequentemente prolonga o internamento ou provoca recorrências e readmissões precoces.

Sugere-se como predisponente para a SPP o uso de ácido aminocaproico durante a cirurgia - cirurgias valvares ou combinadas (coronarianas e valvares). E, em estudo recente, o sexo feminino e a incisão pleural foram registrados como fatores de risco independentes ${ }^{261}$.

A prevenção primária com colchicina ${ }^{262}$ por curto período sugere ser especialmente útil, porém não há evidências que suportem o uso de metilprednisolona ou ácido acetilsalicílico ${ }^{260}$.

O tratamento na fase aguda da SPP é semelhante ao da pericardite aguda, compreende o uso de AINH e colchicina por semanas ou meses, até o desaparecimento da efusão - e a colchicina também está indicada nas recorrências 229,263 . Em casos refratários, o uso de corticoides por via oral (3 a 6 meses) ou pericardiocentese e instilação intrapericárdica de triancinolona são opções relatadas.

\subsection{Neoplasia e pós-radioterapia}

\subsubsection{Neoplasia}

Derrame pericárdico é uma grave complicação de tumores malignos. Essa doença metastática é bem mais frequente, sendo o câncer de pulmão sua principal causa, seguido do câncer de mama, da melanoma, do linfoma e da leucemia ${ }^{264}$.

A evolução clínica costuma ser benigna. Casos sintomáticos podem apresentar desde queixas como desconforto torácico e dispneia, até grave evolução para tamponamento cardíaco ${ }^{265}$. O diagnóstico diferencial da efusão na maioria das vezes é difícil, por isso o diagnóstico definitivo é realizado através do exame citológico do líquido pericárdico.

Para alívio imediato de sintomas a drenagem percutânea e a abordagem cirúrgica são as opções. Na prevenção de recorrências, várias abordagens têm sido propostas: esclerose local, janela pericárdica, quimioterapia sistêmica e/ou local, radioterapia ${ }^{266}$. A bleomicina para esclerose intrapericárdica, em comparação com a drenagem pericárdica isolada, revelou apenas modesto benefício ${ }^{267}$. Nos casos secundários ao adenocarcinoma de pulmão a drenagem cirúrgica parece ser a melhor opção ${ }^{268}$.

\subsubsection{Pericardite por radiação}

A pericardite induzida por radiação pode ocorrer agudamente durante o tratamento radioterápico ou até anos após o seu término. Os pacientes podem se apresentar oligossintomáticos ou com os sintomas mascarados pela doença neoplásica de base. O derrame pode ser hemorrágico ou seroso, podendo evoluir com aderências e constrição. A pericardite deve ser tratada de forma conservadora na ausência de sintomas, ou com pericardiocentese para avaliação na dúvida diagnóstica e nos pacientes com tamponamento. A pericardiectomia está indicada nos pacientes que evoluem com constrição pericárdica, e apresenta alta mortalidade operatória e baixa sobrevida em 5 anos $^{269}$.

\subsection{Pericardite tuberculosa}

A pericardite tuberculosa (PTBC) ocorre em 1-4\% da população com tuberculose (TBC) pulmonar ${ }^{270,271}$ e a TBC é responsável por $7 \%$ dos casos de tamponamento ${ }^{171}$.

A PTBC pode apresentar-se em quatro estágios: seco, efusivo, fase absortiva e fase constritiva ${ }^{272}$. A mortalidade da PTBC não tratada é de aproximadamente $85 \%$. A constrição pericárdica ocorre em $30-50 \%{ }^{273}$

Sua apresentação clínica é variável: pericardite aguda com ou sem derrame; tamponamento cardíaco silencioso; febre persistente; pericardite constritiva aguda, subaguda, efusiva ou crônica; e calcificações pericárdicas ${ }^{274}$.

A PTBC é insidiosa no começo, mas pode começar súbita e dramaticamente em $20-25 \%{ }^{271}$. O ecocardiograma é o melhor método para a confirmação da presença de derrame pericárdico. O diagnóstico é feito pela identificação do Mycobacterium tuberculosis no líquido e/ou tecido pericárdico, e/ou pela presença de granuloma caseoso no pericárdio.

Na PTBC, o líquido pericárdico apresenta alta contagem de proteína e a contagem de leucócitos é altamente variável (700 a 54000/ml). Esses achados não são específicos e somente 40 a $60 \%$ dos pacientes com PTBC submetidos à pericardiocentese tiveram bacilo no exame direto ${ }^{275}$. Também a especificidade do teste tuberculínico tem baixa predictabilidade em áreas onde há alta incidência de TBC. O teste tuberculínico realizado na pele pode ser falso negativo em $25-33 \%$ dos pacientes, e falso positivo em 30-40\% em se tratando de pacientes idosos ${ }^{276}$.

A cultura do líquido pericárdico tem sensibilidade modesta e especificidade de $100 \%{ }^{277}$. A alta atividade da adenosina deaminase (ADA) e a concentração de interferon-c no líquido pericárdico são também diagnósticos, com uma alta sensibilidade e especificidade ${ }^{278}$.

Outro método para detecção de Mycobacterium tuberculosis no líquido pericárdico é o uso de reação da polimerase (PCR), que pode identificar rapidamente o DNA da micobactéria no líquido pericárdico ${ }^{279}$.

Já o uso do teste do interferon-gama (TIG) está aprovado para uso em sangue periférico e não em outros líquidos, tais como líquido pleural ou pericárdico. Não é certo que o TIG no fluido pericárdico tenha vantagens significativas comparadas com a ADA.

O envolvimento perimiocárdico da TBC é também associado com altas titulações de anticorpos antimiosina e antimiolema ${ }^{280}$.

A biópsia pericárdica permite que se faça um rápido diagnóstico, com melhor sensibilidade do que a pericardiocentese (100\% vs. 33\%). A mortalidade relatada em estudos com endoscópio rígido foi de 2,1\% $\%^{281}$ e 3,5\% ${ }^{282}$ devido à indução anestésica em pacientes com derrame pericárdico muito volumoso.

\subsubsection{Tratamento}

Várias combinações de drogas antituberculose de diferentes períodos de duração de tratamento $(6,9,12$ meses) têm sido aplicadas ${ }^{283}$. Somente pacientes com PTBC comprovada ou muito provável devem ser tratados. A prevenção da constrição 


\section{Diretrizes}

no derrame pericárdico crônico de etiologia indeterminada com medicação antituberculose não obteve sucesso ${ }^{284}$.

O uso de esteroides permanece controverso. Uma metaanálise de pacientes com PTBC com derrame e constritiva sugerem que o tratamento via tuberculostáticos combinado com esteroides poderia estar associado com redução da mortalidade, menor necessidade de pericardiocentese ou pericardiectomia ${ }^{285,286}$. Se, a despeito da terapia combinada, há o desenvolvimento de constrição, a pericardiectomia está indicada.

O tratamento medicamentoso para todos os pacientes com PTBC (outras formas de TBC extrapulmonar) é um regime inicial de quatro drogas (tabela 32):

Tabela 32 - Doses terapêuticas e manejo da pericardite tuberculosa.

\begin{tabular}{cc}
\hline $\begin{array}{c}\text { Medicação/ } \\
\text { procedimento }\end{array}$ & Dose/ indicação \\
\hline Isoniazida & $300 \mathrm{mg} \mathrm{VO} \mathrm{1x/dia}$ \\
\hline Rifampina & $600 \mathrm{mg} \mathrm{VO} \mathrm{1x/dia}$ \\
\hline Pirazinamida & 15 a $30 \mathrm{mg} / \mathrm{kg} / \mathrm{dia}$ \\
\hline Etambutol & 15 a $20 \mathrm{mg} / \mathrm{kg} \mathrm{VO} 1 \mathrm{x} / \mathrm{dia}$ \\
\hline Prednisona & $\begin{array}{r}\text { 1-2mg/kg/dia podem ser administrados simultaneamente } \\
\text { progressivamente, redução e descontinuação em } \\
6 \text { a } 8 \text { semanas. }\end{array}$ \\
\hline Após 2 meses & $\begin{array}{c}\text { Interromper o regime de } 4 \text { drogas e manter 2 drogas } \\
\text { (isoniazida e rifampicina) por um total de } 6 \text { meses. }\end{array}$ \\
\hline Pericardiectomia & $\begin{array}{c}\text { Se, apesar despeito combinadada terapia combinada há } \\
\text { o desenvolvimento de constrição e/ou tamponamento }\end{array}$ \\
\hline
\end{tabular}

A fase inicial do tratamento geralmente consiste em terapia diária, ilustrada em cada uma das diferentes opções (tabela 33) ${ }^{287}$.

Tabela 33 - Opções de tratamento inicial preferencial em pericardite tuberculosa.

\begin{tabular}{cc}
\hline & Diariamente isoniazida, rifampicina, pirazinamida e etambutol por 8 \\
semanas, seguindo por 18 semanas com isoniazida e rifampicina \\
diariamente ou 5x na semana.* Pacientes selecionados (HIV negativo, \\
Opção 1 \\
esfregaço negativo aos 2 meses e sem doença cavitária) podem \\
receber isoniazida e rifampicina, ou isoniazida e rifapentina uma vez \\
na semana. ${ }^{*}$ Consultar um especialista em TBC se o paciente for \\
sintomático ou tiver esfregaço ou cultura positivos após 3 meses
\end{tabular}

* todos os esquemas administrados $2 x /$ semana ou $3 x /$ semana devem ser monitorizados diretamente observando a terapia (byDOT). Adapted from American Thoracic Society/Centers for Disease Control/Infectious Diseases Sociey of America ${ }^{287}$.

\subsection{Bacteriana e fúngica}

As pericardites purulentas apresentam elevada morbidade e mortalidade, porém são raras nos adultos ${ }^{288}$. As condições predisponentes são doença de derrame pericárdico préexistente, cirurgia cardíaca ou trauma torácico recente, DRC, imunossupressão, abuso de álcool, artrite reumatoide e neoplasias malignas. A etiologia fúngica é mais rara ainda e habitualmente ocorre em pacientes com infecções fúngicas em outros sítios ${ }^{289}$.

A apresentação mais comum é a de doença infecciosa aguda, sendo pouco frequentes a dor torácica e o atrito pericárdico. Podem-se observar anemia, leucocitose, alterações eletrocardiográficas e radiográficas, porém o ecocardiograma é um dos métodos mais utilizados para detectar e quantificar derrames pericárdicos. Outros métodos podem ser utilizadosm, como a tomografia computadorizada e a ressonância cardíaca ${ }^{290}$.

A suspeita diagnóstica se faz através do quadro clínico, quando da presença de derrame pericárdico ao ecocardiograma. A confirmação diagnóstica depende da pericardiocentese com realização de Gram, cultura, além de pesquisa para fungos e tuberculose. Os agentes Gram positivos são mais prevalentes $(64,2 \%)$, seguidos pelos Gram negativos $(27,7 \%)$ e fungos $(1,4 \%)^{291,292}$.

O tratamento é através de drenagem do líquido pericárdico por pericardiocentese e uso de antimicrobianos, inicialmente para estafilococo, até se obter os resultados da cultura. Em casos de derrames septados em várias lojas, o uso de trombolíticos pode ser considerado, em especial a estreptoquinase na dose de 500.000UI a cada 12 horas (total de três doses) $)^{293,294}$. A realização de drenagem pericárdica com pericardiectomia é o procedimento de escolha, principalmente nas formas persistentes ou recorrentes ${ }^{168}$.

As indicações para o diagnóstico e tratamento da pericardite purulenta se encontram na tabela 34.

Tabela 34 - Indicações para diagnóstico e tratamento da pericardite purulenta.

\begin{tabular}{|c|c|c|}
\hline $\begin{array}{l}\text { Classe de } \\
\text { recomendação }\end{array}$ & Indicações & $\begin{array}{l}\text { Nível de } \\
\text { evidência }\end{array}$ \\
\hline Classe I & $\begin{array}{l}\text { Na suspeita clínica de pericardite purulenta, } \\
\text { realizar pericardiocentese para o diagnóstico }\end{array}$ & B \\
\hline Classe I & $\begin{array}{l}\text { Pericardiotomia para o tratamento de } \\
\text { pericardite purulenta }\end{array}$ & B \\
\hline Classe I & $\begin{array}{l}\text { O uso de antimicrobiano preferencialmente } \\
\text { guiado pelos achados da pericardiocentese } \\
\text { para o tratamento de pericardite purulenta }\end{array}$ & A \\
\hline Classe lla & $\begin{array}{l}\text { Anti-inflamatório não hormonal para o } \\
\text { tratamento de pericardite purulenta }\end{array}$ & B \\
\hline Classe Ila & $\begin{array}{c}\text { Colchicina para o tratamento de } \\
\text { pericardite purulenta }\end{array}$ & B \\
\hline Classe Ila & $\begin{array}{c}\text { Trombolítico intrapericárdico para o } \\
\text { tratamento de pericardite purulenta com } \\
\text { derrames pericárdicos com várias lojas e } \\
\text { muita fibrina }\end{array}$ & C \\
\hline Classe Ila & $\begin{array}{c}\text { Pericardiectomia para o tratamento } \\
\text { das formas recorrente e persistente de } \\
\text { pericardite purulenta }\end{array}$ & B \\
\hline Classe Ila & $\begin{array}{l}\text { Corticoesteroides orais no tratamento } \\
\text { das formas persistentes de pericardite } \\
\text { purulenta para atenuar sintomas }\end{array}$ & C \\
\hline Classe Ilb & $\begin{array}{l}\text { Corticosteroides no tratamento da } \\
\text { pericardite purulenta }\end{array}$ & $C$ \\
\hline
\end{tabular}




\subsection{Auto-imunes}

Processos autoimunes de envolvimento sistêmico podem resultar em pericardite ${ }^{295}$ como observado em artrite reumatoide, lúpus eritematoso sistêmico, esclerose sistêmica múltipla, polimiosite, doença mista do colágeno, espondilites soronegativas, síndrome de Sjogren, vasculites sistêmicas, síndrome de Behcet, granulomatose com poliangeíte, sarcoidose, entre outras.

O quadro clínico varia desde o de um achado assintomático até uma manifestação de pericardite aguda, menos comumente de tamponamento, havendo registros de pericardite constritiva transitória ${ }^{296}$. Sua evolução para pericardite constritiva crônica é rara. O manuseio das formas habituais geralmente se dirige para o tratamento habitual da causa subjacente.

Uma forma isolada de pericardite autoimune tem sido descrita, quando uma sistemática procura de evidências de autoagressão é demonstrada, por exemplo, pelo predomínio de linfócitos ou o achado de autoanticorpos contra sarcolema ${ }^{297}$ no líquido pericárdico. Exclui-se a presença de vírus ou de outros agentes infecciosos (ausência de lgM contra vírus cardiotrópicos no líquido pericárdico e pesquisa de PCR negativo para tais agentes), além de doenças sistêmicas ou neoplásicas.

O tratamento é o usual da pericardite aguda e do derrame pericárdico, associado à abordagem terapêutica da doença de base (tabela 35).

O uso de triancinolona intrapericárdica $300 \mathrm{mg} / \mathrm{m}^{2} / 24 \mathrm{~h}$ diluída em $100 \mathrm{ml}$ de soro, mostrou-se eficaz em aliviar sintomas e prevenir recorrências, evitando os efeitos colaterais de corticoide oral ${ }^{298}$.

Tabela 35 - Indicações de tratamento da pericardite autoimune.

\begin{tabular}{ccc}
\hline $\begin{array}{c}\text { Classe de } \\
\text { recomendação }\end{array}$ & Indicações & $\begin{array}{c}\text { Nível de } \\
\text { evidência }\end{array}$ \\
\hline Classe I & AlNE no tratamento inicial de pericardite \\
autoimune & B & B \\
\hline Classe I & $\begin{array}{c}\text { Colchicina no tratamento das recidivas de } \\
\text { pericardite autoimune }\end{array}$ & B \\
\hline Classe I & $\begin{array}{c}\text { Corticosteroides sistêmicos em dose baixa } \\
\text { para o tratamento de casos refratários de } \\
\text { pericardite autoimune (não responsivos a } \\
\text { AlNEs ou colchicina) }\end{array}$ & B \\
\hline Classe I & $\begin{array}{c}\text { Indicação cirúrgica de derrame pericárdico } \\
\text { refratário secundário a quilotórax pós } \\
\text { cirurgia cardíaca }\end{array}$ & B \\
\hline Classe lla & $\begin{array}{c}\text { Possibilidade de uso de corticosteroide } \\
\text { intrapericárdico em casos de } \\
\text { refratariedade }\end{array}$ & B \\
\hline Classe III & $\begin{array}{l}\text { Corticosteroides sistêmicos em dose alta } \\
\text { para o tratamento de casos refratários de } \\
\text { pericardite autorimune }\end{array}$ & \\
\hline
\end{tabular}

\subsection{Quilopericárdio e hipotireoidismo}

Quilopericárdio se refere à condição de acúmulo de material de drenagem do ducto torácico no pericárdio como resultado de fístula, complicando cirurgia de mediastino, cirurgia cardiovascular, traumatismo torácico, tumores mediastínicos ou anomalias congênitas do ducto torácico ${ }^{250}$.
O líquido pericárdico é de aspecto branco leitoso, opalescente, com alto conteúdo de triglicerídeos (5-50 g/L) e proteína(22-60 g/L) e gorduras. A ressonância magnética traz grandes subsídios para firmar o diagnóstico por meio da sequência dos sinais T1 e T2 ${ }^{299}$.

Eventualmente se confunde com o de outras etiologias e somente é esclarecido após exploração cirúrgica do pericárdio ${ }^{300}$. O tratamento é de acordo com a etiologia e a quantidade de líquido pericárdico. Em situações em que este é secundário a cirúrgica cardíaca ou torácica, sem sinais de tamponamento, o tratamento poderá ser conduzido com punção ocasional e dieta com triglicérides de cadeia média ${ }^{301}$. Em casos refratários ao tratamento conservador, cirurgia com derivação pericardioperitoneal ou de forma alternativa à ligadura do ducto torácico, quando se consegue identificar o seu percurso ${ }^{302}$.

Derrame pericárdico em hipotireoidismo é relativamente comum, sendo registrado em 30 a $80 \%$ dos casos mais avançados da doença e em 3 a $6 \%$ das formas mais precoces ${ }^{303}$. Embora raramente se complique por tamponamento, essa ocorrência pode ser registrada, e uma pista para seu desenvolvimento pode ser a da presença de frequência cardíaca inesperadamente elevada num quadro de hipotireoidismo, com baixa voltagem de QRS ${ }^{304}$.

O tratamento do derrame pericárdico é facilmente obtido com o tratamento do hipotireoidismo (tabela 36).

Tabela 36 - Indicações no quilopericárdio e no hipotireoidismo.

\begin{tabular}{ccc}
\hline $\begin{array}{c}\text { Classe de } \\
\text { recomendação }\end{array}$ & Indicações & $\begin{array}{c}\text { Nível de } \\
\text { evidência }\end{array}$ \\
\hline I & $\begin{array}{c}\text { Cirurgia em casos refratários de } \\
\text { quilopericárdio pós-cirurgia cardíaca }\end{array}$ & B \\
\hline I & $\begin{array}{c}\text { Tratamento do derrame pericárdico em } \\
\text { hipotireoidismo com reposição tireoidiana }\end{array}$ & B \\
\hline
\end{tabular}

\subsection{Pós-infarto agudo do miocárdio}

As duas formas de manifestação da pericardite após o IAM são a pericardite epistenocárdica, com apresentação "precoce", também chamada pericardite peri-infarto, e a pericardite "tardia" pós-infarto, ou síndrome de Dressler. A incidência de ambas está em declínio ${ }^{305,306}$. Dor pericárdica e atrito pericárdico definem a pericardite peri-infarto e geralmente ela se desenvolve no $2^{\circ}$ ou $3^{\circ}$ dia após um IAM transmural. As manifestações eletrocardiográficas são de difícil identificação, pois são superpostas pelas alterações do infarto. A persitência de ondas T invertidas ou a normalização destas pode sugerir a presença de pericardite. O curso clínico é benigno, e o prognóstico do paciente não é alterado pelo desenvolvimento desta complicação.

A pericardite pós-infarto ocorre em aproximadamente $5 \%$ a $6 \%$ de pacientes trombolisados e desenvolve-se normalmente durante a segunda semana, podendo vir a se manifestar meses pós o IAM. Deve ser suspeitada em qualquer paciente com dor pleuropericárdica. Atrito pericárdico pode ou não se manifestar. A diferenciação de pericardite e angina recorrente pode ser difícil, mas uma história cuidadosa e avaliação eletrocardiográfica seriada podem ajudar na distinção. A 
maioria dos casos tem curso benigno; no entanto, como está associada a infartos maiores, a taxa de mortalidade global em longo prazo é maior ${ }^{307}$.

Complicações raras incluem hemopericárdio, tamponamento cardíaco e pericardite constritiva. A terapia é direcionada para o alívio da dor, geralmente respondendo bem a antiinflamatórios não esteroidais. No entanto, permanece em grande parte empírica devido à relativa falta de ensaios clínicos controlados ${ }^{308,309}$. Além disso, a duração do tratamento também não está bem estabelecida: podemos, entretanto, gerar algumas recomendações. O ibuprofeno, 1600-3200 mg/dia, por até 2 semanas, tem sido o fármaco de escolha por aumentar o fluxo sanguíneo coronariano e apresentar menor incidência de efeitos adversos 224,310 . AAS, 2-4 g/ dia, por 2 a 5 dias também pode ser utilizado com igual eficácia (4). Para pacientes com sintomas refratários e recorrentes, a colchicina, $0,6 \mathrm{mg}$, duas vezes ao dia, é preferível a corticosteroides orais, que devem ser restritos a baixas doses (prednisona, 0,2-0,5 mg/ kg / dia) ${ }^{223,311,312}$.

\subsection{HIV}

A doença pericárdica é a manifestação clínica mais frequente da doença cardiovascular em pacientes com AIDS. O derrame pericárdico (DP) ocorre em 20\% (10 a $40 \%$ ), sendo volumoso em 4\%313-316, sendo $2 / 3$ são causados por infecção ou neoplasia, e esta relacionada a um pior prognóstico ${ }^{317}$.

O quadro clínico da pericardite no HIV é similar ao de outras etiologias. O achado do M. tuberculosis é frequente em pacientes com HIV ${ }^{318-323}$, sendo que o teste da tuberculina negativo não exclui o diagnóstico. Além disso, a biópsia pericárdica é mais sensível do que esfregaço e cultura de líquido pericárdico, mas pode não ser positiva para granuloma caseoso. A pericardite por citomegalovírus (CMV) também apresenta maior incidência em portadores do vírus HIV $324,325$.

O tratamento da pericardite em portadores de HIV é sintomático e preventivo. Se o derrame é sintomático, recorrente ou crônico, com confirmada infecção viral, o tratamento específico deve ser instituído ${ }^{242}$.

O tamponamento cardíaco ocorre entre 33 e 40\% dos casos, e a drenagem imediata é necessária. Se o derrame pericárdico for volumoso em pacientes portadores de AIDS, sem etiologia estabelecida, o tratamento empírico para M. tuberculosis está indicado ${ }^{326-328}$.

\subsection{Pós-traumática e por dissecção aórtica}

\subsubsection{Pós-traumática}

A pericardite pós-traumática é secundária a acidentes ou ferimentos iatrogênicos, sendo que, nestes casos, situações mais graves podem levar ao derrame e tamponamento pericárdico, o que gera necessidade de intervenção cirúrgica de emergência. A lesão do tórax e do coração, fechada ou penetrante com contusão miocárdica, pode provocar pericardite. Essa pericardite, no entanto, possui pouca significância clínica e pode se desenvolver dias ou meses após a lesão cardíaca ou torácica. O processo inflamatório parece ser devido à produção de anticorpos como resposta à injúria miocárdica. A pericardite pós-cirurgia cardíaca tem sido reportada em 20\% dos casos de cirurgia de revascularização miocárdica, desenvolvendo-se de dias a meses após a intervenção.

A pericardite iatrogênica ocorre infrequentemente em menos de $0.2 \%$ de intervenções percutâneas. Entre as mais frequentes temos valvuloplastia mitral percutânea, punção transeptal, transecção de artéria coronária após angioplastia, biópsia endomiocárdica, implante de eletrodo de marcapasso no ventrículo direito ou implante de eletrodos epicárdicos.

Outra situação de pericardite por injúria ocorre nos casos de radiação torácica ou mediastinal, utilizada para a terapêutica de uma variedade de neoplasias, principalmente a doença de Hodgkin, os linfomas não Hodgkin e o carcinoma de mama. A probabilidade de desenvolver a pericardite está relacionada à fonte de aplicação da radiação, à dose, ao fracionamento, à duração, ao volume de exposição, ao campo de aplicação e à idade do paciente. A pericardite induzida pela radiação pode ocorrer durante a terapia ou meses e anos mais tarde $\mathrm{e}^{167,168}$.

\subsubsection{Por dissecção aórtica}

$\mathrm{Na}$ dissecção aórtica o derrame pericárdico ocorre em $17-45 \%$ dos pacientes e em $48 \%$ das autópsias ${ }^{329}$. A dissecção da aorta ascendente é comumente complicada com hemopericárdio que pode ser fatal. O diagnóstico é estabelecido usualmente por ecocardiograma transesofágico, tomografia do tórax ou ressonância do coração e da aorta ${ }^{330}$.

A pericardiocentese está contraindicada pelo risco de aumentar o sangramento e agravar a dissecção. Os pacientes devem ser submetidos imediatamente a cirurgia para correção da aorta e drenagem pericárdica ${ }^{331}$.

\subsection{Pericardite recorrente}

A pericardite recorrente geralmente ocorre de 18 a 20 meses após um episódio inicial de pericardite que foi resolvida. Ela pode surgir em cerca de 15 a 32\% dos casos e apresenta-se sob duas formas: intermitente (períodos sem sintomas na ausência de tratamento) e incessante (a suspensão do tratamento faz com que os sintomas retornem) ${ }^{168,254}$. Os mecanismos envolvidos no desenvolvimento da recorrência são: 1) tratamento inadequado com AINH ou corticoide (dose, tempo); 2) uso inadequado de corticóide, ocasionando replicação viral; 3) reinfecção viral; 4) reativação de doença autoimune.

A utilização de colchicina é a terapêutica mais segura e eficaz para prevenção da pericardite, principalmente quando o uso de AINH ou corticoide não falharam em impedir a recorrência ${ }^{332}$.

A terapia com corticoides está indicada nos pacientes com recorrência frequente ou com importante comprometimento clínico. Na ausência de resposta 
Diretrizes

adequada ao corticosteroide, pode-se associar azatioprina ou ciclosporina ${ }^{206}$. Um dos principais fatores determinantes da recorrência é a redução rápida da dose de corticoide, que não deve ser feita num período inferior a três meses.

A pericardiectomia está indicada para os casos com recorrência frequente, muito sintomática e refratária à terapêutica ${ }^{333-335}$.

A tabela 37 resume as indicações para o tratamento na pericardite recorrente.
Tabela 37 - Indicações para o tratamento da pericardite recorrente.

\begin{tabular}{ccc}
\hline $\begin{array}{c}\text { Classe de } \\
\text { recomendação }\end{array}$ & Indicações & $\begin{array}{c}\text { Nível de } \\
\text { evidência }\end{array}$ \\
\hline Classe I & $\begin{array}{c}\text { Colchicina por 6 meses no tratamento da } \\
\text { pericardite recorrente }\end{array}$ & B \\
\hline Classe Ila & $\begin{array}{c}\text { Asprina ou ibuprofeno para o tratamento } \\
\text { da pericardite recorrente }\end{array}$ & B \\
\hline Classe Ila & $\begin{array}{c}\text { Colchicina para o tratamento de pericardite } \\
\text { pós infarto agudo do miocárdio }\end{array}$ & B \\
\hline Classe Ilb & $\begin{array}{c}\text { Pericardiectomia no tratamento de } \\
\text { pericardite recorrente para casos } \\
\text { refratários e muito sintomáticos }\end{array}$ & B \\
\hline Classe Ilb & $\begin{array}{c}\text { Corticosteroides sistêmicos no tratamento } \\
\text { da pericardite recorrente após falha no } \\
\text { tratamento com AlNEs e colchicina }\end{array}$ & C \\
\hline Classe Ilb & $\begin{array}{c}\text { Utilização de outros agentes } \\
\text { imunossupressores (azatioprina e } \\
\text { ciclosporina) nas recorrências por } \\
\text { doenças auto-imunes ou do colágeno }\end{array}$ & C \\
\hline
\end{tabular}




\section{Referências}

1. Carniel E, Sinagra G, Bussani R, Di Lenarda A, Pinamonti B, Lardieri G, etal. Fatal myocarditis: morphologic and clinical features. Ital Heart J. 2004;5(9):702-6.

2. Kytö V, Saraste A, Voipio-Pulkki LM, Saukko P. Incidence of fatal myocarditis: a population-based study in Finland. Am J Epidemiol. 2007;165(5):570-4.

3. Hahn EA, Hartz VL, Moon TE, O'Connell JB, Herskowitz A, McManus BM, et al. The Myocarditis Treatment Trial: design, methods and patients enrollment. Eur Heart J. 1995; 16 (Suppl O):162-7.

4. Kühl U, Pauschinger M, Noutsias M, Seeberg B, Bock T, Lassner D, et al. High prevalence of viral genomes and multiple viral infections in the myocardium of adults with "idiopathic" left ventricular dysfunction. Circulation. 2005;111(7):887-93.

5. Neuspiel DR, Kuller LH. Sudden and unexpected natural death in childhood and adolescence. JAMA. 1985;254(10):1321-5.

6. Rahman JE, Helou EF, Gelzer-Bell R, Thompson RE, Kuo C, Rodriguez ER, et al. Noninvasive diagnosis of biopsy- proven cardiac amyloidosis. J Am Coll Cardiol. 2004;43(3):410-5.

7. Frustaci A, Verardo R, Caldarulo M, Acconcia MC, Russo MA, Chimenti C. Myocarditis in hypertrophic cardiomyopathy patients presenting acute clinical deterioration. Eur Heart J. 2007;28(6):733-40.

8. JCS Joint Working Group. Guidelines for diagnosis and treatment of myocarditis (JCS 2009): digest version. Circ J. 2011;75(3):734-43.

9. Montera MW, Pereira Y, Silva EL, Takiya C, Mesquita ET. Accuracy of non invasive methods to diagnose Chronic Myocarditis in patients with dilated cardiomyophaty. Eur J Heart Fail. 2011; . S10: S162-S165.

10. Blauwet LA, Cooper LT. Myocarditis. Prog Cardiovasc Dis. 2010;52(4):274-88.

11. McAlister HF, Klementowicz PT, Andrews C, Fisher JD, Feld M, Furman S. Lyme carditis: an important cause of reversible heart block. Ann Intern Med. $1989 ; 110(5): 339-45$.

12. Andrade JP, Marin-Neto JA, Paola AA, Vilas-Boas F, Oliveira GM, Bacal F, et al; Sociedade Brasileira de Cardiologia. I Diretriz Latino Americana para o diagnóstico e tratamento da cardiopatia chagásica. Arq Bras Cardiol. 2011;97(2 supl. 3):1-47.

13. Kilian JG, Kerr K, Lawrence C, Celermajer DS. Myocarditis and cardiomyopathy associated with clozapine. Lancet. 1999;354(9193):1841-5.

14. Stelts S, Taylor MH, Nappi J, Van Bakel AB. Mesalamine associated hypersensitivity myocarditis in ulcerative colitis. Ann Pharmacother. 2008;42(6):904-5.

15. Murphy JG, Wright RS, Bruce GK, Baddour LM, Farrell MA, Edwards WD, et al. Eosinophilic-lymphocytic myocarditis after smallpox vaccination. Lancet. 2003;362(9393):1378-80.

16. Cassimatis DC, Atwood JE, Engler RM, Linz PE, Grabenstein JD, Vernalis MN. Smallpox vaccination and myopericarditis: a clinical review. J Am Coll Cardiol. 2004;43(9):1503-10.

17. Corssmit EP, TripMD, Durrer JD. Loeffler's endomyocarditis in the idiopathic hypereosinophilic syndrome. Cardiology. 1999;91(4):272-6.

18. Nunes H, Freynet O, Naggara N, Soussan M, Weinman P, Diebold B, et al. Cardiac sarcoidosis. Semin Respir Crit Care Med. 2010;31(4):428-41.

19. Cooper LT Jr. Giant cell and granulomatous myocarditis. Heart Fail Clin. 2005;1(3):431-7.

20. Felker GM, Jaeger CJ, Klodas E, Thiemann DR, Hare JM, Hruban RH, et al. Myocarditis and long-term survival in peripartum cardiomyopathy. Am Heart J. 2000;140(5):785-91.

21. Midei MG, DeMent SH, Feldman AM, Hutchins GM, Baughman KL. Peripartum myocarditis and cardiomyopathy. Circulation. 1990;81(3):922-8.

22. Kindermann I, Barth C, Mahfoud F, Ukena C, Lenski M, Yilmaz A, et al. Update on myocarditis. J Am Coll Cardiol. 2012;59(9):779-92.
23. Kawai C. From myocarditis to cardiomyopathy: mechanisms of inflammation and cell death: learning from the past for the future. Circulation. 1999;99(8):1091-100.

24. Yuen S, Smith J, Caruso L, Balan M, Opavsky MA. The coxsackie-adenovirus receptor induces an inflammatory cardiomyopathy independent of viral infection. J Mol Cell Cardiol. 2011;50(5):826-40.

25. Oakley CM. Myocarditis, pericarditis and other pericardial diseases. Heart. 2000;84(4):449-54.

26. Ammann P, Naegeli B, Schuiki E, Straumann E, Frielingsdorf J, Rickli H, et al. Long-term outcome of acute myocarditis is independent of cardiac enzyme release. Int J Cardiol. 2003;89(2-3):217-22.

27. Mason JW. Myocarditis. Adv Intern Med. 1999;44:293-310.

28. Andréoletti L, Lévêque N, Boulagnon C, Brasselet C, Fornes P. Viral causes of human myocarditis. Arch Cardiovasc Dis. 2009;102(6-7):559-68.

29. Cooper LT Jr. Myocarditis. N Engl J Med. 2009;360(15):1526-38.

30. Taliercio CP, Olney BA, Lie JT. Myocarditis related to drug hypersensitivity. Mayo Clin Proc. 1985;60(7):463-8.

31. Arness MK, Eckart RE, Love SS, Atwood JE, Wells TS, Engler RJ, et al. Myopericarditis following smallpox vaccination. Am J Epidemiol. 2004;160(7):642-51.

32. Spodick DH. Eosinophilic myocarditis. Mayo Clin Proc. 1997;72(10):996.

33. Narula N, McNamara DM. Endomyocardial biopsy and natural history of myocarditis. Heart Fail Clin. 2005;1(3):391-406.

34. Rosenstein ED, Zucker MJ, Kramer N. Giant cell myocarditis: most fatal of autoimmune diseases. Semin Arthritis Rheum. 2000;30(1):1-16.

35. Baughman RP, Lower EE, du Bois RM. Sarcoidosis. Lancet. 2003;361(9363):1111-8.

36. Thomas PD, Hunninghake GW. Current concepts of the pathogenesis of sarcoidosis. Am Rev Respir Dis. 1987;135(3):747-60.

37. Caforio AL, Calabrese F, Angelini A, Tona F, Vinci A, Bottaro S, et al. A prospective study of biopsy-proven myocarditis: prognostic relevance of clinical and aetiopathogenetic features at diagnosis. Eur Heart J. 2007;28(11):1326-33.

38. Montera MW, Karinina A, Lycurgo G, Silva EE, Takya C, Evandro T, et al. Clinical and functional profile of patients with viral miocarditis vs non viral miocarditis. J Card Fail. 2006;12(6 Suppl):S28.

39. Magnani JW, Dec GW. Myocarditis: current trends in diagnosis and treatment. Circulation. 2006;113(6):876-90.

40. Dec GW Jr, Palacios IF, Fallon JT, Aretz HT, Mills J, Lee DC, et al. Active myocarditis in the spectrum of acute dilated cardiomyopathies: clinical features, histologic correlates, and clinical outcome. N Engl J Med. 1985;312(14):885-90.

41. Amabile NF, Fraisse A, Bouvenot J, Chetaille P, Ovaert C. Outcome of acute fulminant myocarditis in children. Heart. 2006;92(9):1269-73.

42. Morimoto S, Kato S, Hiramitsu S, Uemura A, Ohtsuki M, Kato Y, et al. Role of myocardial interstitial edema in conduction disturbances in acute myocarditis. Heart Vessels. 2006;21(6):356-60.

43. Yazaki Y, Isobe M, Hiramitsu S, Morimoto S, Hiroe M, Omichi C, et al. Comparison of clinical features and prognosis of cardiac sarcoidosis and idiopathic dilated cardiomyopathy. Am J Cardiol. 1998;82(4):537-40.

44. Mahfoud F, Gärtner B, Kindermann M, Ukena C, Gadomski K, Klingel K, et al. Virus serology in patients with suspected myocarditis: utility or futility? Eur Heart J. 2011;32(7):897-903.

45. Morgera T, Di Lenarda A, Dreas L, Pinamonti B, Humar F, Bussani $\mathrm{R}$, et al. Electrocardiography of myocarditis revisited: clinical and prognostic significance of electrocardiographic changes. Am Heart J. 1992;124(2):455-67. 
46. Nakashima H, Katayama T, Ishizaki M, Takeno M, Honda Y, Yano K. Q wave and non-Q wave myocarditis with special reference to clinical significance. Jpn Heart J. 1998;39(6):763-74

47. Mangini S, Conceição-Souza GE, Ramires JAF. Pericardites. In: Veronesi R. Tratado de infectologia. 3a ed. São Paulo: Atheneu; 2005. p. 2067-94.

48. Pinamonti B, Alberti E, Cigalotto A, Dreas L, Salvi A, Silvestri F, et al. Echocardiographic findings in myocarditis. Am J Cardiol. 1988;62(4):285-91.

49. Escher F, Westermann D, Gaub R, Pronk J, Bock T, Al-Saadi N, et al. Development of diastolic heart failure in a 6-year follow-up study in patients after acute myocarditis. Heart. 2011;97(9):709-14.

50. Angelini A, Calzolari V, Calabrese F, Boffa GM, Maddalena F, Chioin R, et al. Myocarditis mimicking acute myocardial infarction: role of endomyocardial biopsy in the differential diagnosis. Heart. 2000;84(3):245-50.

51. Mendes LA, Dec GW, Picard MH, Palacios IF, Newell J, Davidoff R. Right ventricular dysfunction: an independent predictor of adverse outcome in patients with myocarditis. Am Heart J. 1994;128(2):301-7.

52. Felker GM, Boehmer JP, Hruban RH, Hutchins GM, Kasper EK, Baughman $\mathrm{KL}$, et al. Echocardiographic findings in fulminant and acute myocarditis. J Am Coll Cardiol. 2000;36(1):227-32.

53. Friedrich MG, Sechtem U, Schulz-Menger J, Holmvang G, Alakija P, Cooper LT, et al. International Consensus Group on Cardiovascular Magnetic Resonance in Myocarditis. Cardiovascular magnetic resonance in myocarditis: a JACC White Paper. J Am Coll Cardiol. 2009;53(17):1475-87.

54. Abdel-Aty H, Boye P, Zagrosek A, Wassmuth R, Kumar A, Messroghli D, et al. Diagnostic performance of cardiovascular magnetic resonance in patients with suspected acute myocarditis: comparison of different approaches. J Am Coll Cardiol. 2005;45(11):1815-22.

55. Friedrich MG, Strohm O, Schulz-Menger J, Marciniak H, Luft FC, Dietz R. Contrast media-enhanced magnetic resonance imaging visualizes myocardial changes in the course of viral myocarditis. Circulation. 1998;97(18):1802-9.

56. De Cobelli F, Pieroni M, Esposito A, Chimenti C, Belloni E, Mellone R, et al. Delayed gadolinium-enhanced cardiac magnetic resonance in patients with chronic myocarditis presenting with heart failure or recurrent arrhythmias. J Am Coll Cardiol. 2006;47(8):1649-54.

57. Mahrholdt H, Goedecke C, Wagner A, Meinhardt G, Athanasiadis A, Vogelsberg $\mathrm{H}$, et al. Cardiovascular magnetic resonance assessment of human myocarditis: a comparison to histology and molecular pathology. Circulation. 2004;109(10):1250-8.

58. Mahrholdt H, Wagner A, Deluigi CC, Kispert E, Hager S, Meinhardt G, et al. Presentation, patterns of myocardial damage, and clinical course of viral myocarditis. Circulation. 2006;114(15):1581-90.

59. Grün S, Schumm J, Greulich $S, W$ agner $A$, Schneider S, Bruder O, et al. Long-term follow-up of biopsy-proven viral myocarditis predictors of mortality and incomplete recovery. J Am Coll Cardiol. 2012;59(18):1604-15.

60. Sparrow PJ, Merchant N, Provost YL, Doyle DJ, Nguyen ET, Paul NS. CT and MR imaging findings in patients with acquired heart disease at risk for sudden cardiac death. Radiographics. 2009;29(3):805-23.

61. Boussel L, Gamondes D, Staat P, Elicker BM, Revel D, Douek P. Acute chest pain with normal coronary angiogram: Role of contrast-enhanced multidetector computed tomography in the differential diagnosis between myocarditis and myocardial infarction. J Comput Assist Tomogr. 2008;32(2):228-32.

62. O'Connell JB, Henkin RE, Robinson JA, Subramanian R, Scanlon PJ, Gunnar RM. Gallium-67 imaging in patients with biopsy-proven myocarditis. Circulation. 1984;70(1):58-62

63. Dec GW. Introduction to clinical myocarditis. In: Cooper LT. (editor). Myocarditis: from bench to bedside. Totowa, NJ: Humana Press; 2003. p. 257-81.
64. Margari ZJ, Anastasiou-Nana MI, Terrovitis J, Toumanidis S, Agapitos EV Lekakis JP, et al. Indium-111 monoclonal antimyosin cardiac scintigraphy in suspected acute myocarditis: evolution and diagnostic impact. Int J Cardiol. 2003;90(2-3):239-45

65. Montera MW, Almeida DR, Peixoto CM, Takiya C, Mesquita CT, Mesquita ET. Correlation between gallium scanning and clinical characteristics, left ventricular systolic function, and immunologic alterations in patients with active lymphocite myocarditis. J Card Fail. 2004;10(4 Suppl):S82.

66. Cooper LT, Baughman K, Feldman AM, Frustaci A, Jessup M, Kuhl U, et al. The role of endomyocardial biopsy in the management of cardiovascular disease: a scientific statement from the American Heart Association, the American College of Cardiology, and the European Society of Cardiology Endorsed by the Heart Failure Society of America and the Heart Failure Association of the European Society of Cardiology. Eur Heart J. 2007;28(24):3076-93.

67. Cooper LT Jr, Berry GJ, Shabetai R. Idiopathic giant-cell myocarditis: natural history and treatment. Multicenter Giant Cell Myocarditis Study Group Investigators. N Engl J Med. 1997;336(26):1860-6.

68. Shields RC, Tazelaar HD, Berry GJ, Cooper LT Jr. The role of right ventricular endomyocardial biopsy for idiopathic giant cell myocarditis. J Card Fail. 2002;8(2):74-8.

69. Takada K, Ina Y, Yamamoto M, Satoh T, Morishita M. Prognosis after pacemaker implantation in cardiac sarcoidosis in Japan: clinical evaluation of corticosteroid therapy. Sarcoidosis. 1994;11(2):113-7.

70. Wojnicz R, Nowalany-Kozielska E, Wojciechowska C, Glanowska G, Wilczewski P, Niklewski T, et al. Randomized, placebo-controlled study for immunosuppressive treatment of inflammatory dilated cardiomyopathy: two-year follow-up results. Circulation. 2001;104(1):39-45.

71. Feldman AM, Lorell BH, Reis SE. Trastuzumab in the treatment of metastatic breast cancer: anticancer therapy versus cardiotoxicity. Circulation. 2000; 102(3):272-4

72. Oakes DF, Manolis AS, Estes NA 3rd. Limited clinical utility of endomyocardia biopsy in patients presenting with ventricular tachycardia without apparent structural heart disease. Clin Cardiol. 1992;15(1):24-8.

73. Sakakibara S, Konno S. Endomyocardial biopsy. Jpn HeartJ. 1962;3:537-43

74. Copeland JG, Valdes-Cruz L, Sahn DJ. Endomyocardial biopsy with fluoroscopic and two-dimensional echocardiographic guidance: case report of a patient suspected of having multiple cardiac tumors. Clin Cardiol. 1984;7(8):449-52.

75. Rabischoffsky A. Biópsia miocárdica guiada pelo ecocardiograma. Rev Bras Ecocardiogr. 2008;21(2):27-30.

76. Mavrogeni SI, Markussis V, Kaklamanis L, Tsiapras D, Paraskevaidis I, Karavolias G, et al. A comparison of magnetic resonance imaging and cardiac biopsy in the evaluation of heart iron overload in patients with betathalassemia major. Eur J Haematol. 2005;75(3):241-7.

77. Bowles NE, Ni J, Kearney DL, Pauschinger M, Schultheiss HP, McCarthy R, et al. Detection of viruses in myocardial tissues by polymerase chain reaction: evidence of adenovirus as a common cause of myocarditis in children and adults. J Am Coll Cardiol. 2003;42(3):466-72.

78. Richardson PJ. Endomyocardial biopsy technique. In: Bolte HD. Myocardial biopsy: diagnostic significance. Berlin: Springer Verlag; 1982.

79. Fowles RF, Mason JW. Myocardial biopsy (editorial). Mayo Clinic Proc. 1982;459-62.

80. Baughman KL. Diagnosis of myocarditis: death of Dallas criteria. Circulation. 2006;113(4):593-5.

81. Maisch B, Herzum M, Hufnagel G, Schönian U. Immunosuppressive and immunomodulatory treatment for myocarditis. Curr Opin Cardiol. $1996 ; 11(3): 310-24$

82. Meinardi MT, van der Graaf WT, van Veldhuisen DJ, Gietema JA, de Vries EG, Sleijfer DT. Detection of anthracycline-induced cardiotoxicity. Cancer Treat Rev. 1999;25(4):237-47. 
83. Badorff C, Noutsias M, Kühl U, Schultheiss HP. Cell-mediated cytotoxicity in hearts with dilated cardiomyopathy: correlation with interstitial fibrosis and foci of activated T lymphocytes. J Am Coll Cardiol. 1997;29(2):429-34.

84. Noutsias M, Pauschinger M, Schultheiss H, et al. Phenotypic characterization of infiltrates in dilated cardiomyopathy: diagnostic significance of T-lymphocytes and macrophages in inflammatory cardiomyopathy. Med Sci Monit. 2002;8(7):CR478-87.

85. Milei J, Bortman G, Fernandez-Alonso G, Grancelli H, Beigelman R. Immunochemical staining of lymphocytes for the reliable diagnosis of myocarditis in endomyocardial biopsies. Cardiology. 1990;77(2):77-85.

86. Kuhl U, Noutsias M, Seeberg B. Immunohistological evaluation of myocardial biopsies from patients with dilated cardiomyopathy. J Heart Fail. 1994;9:231-45.

87. Kühl U, Noutsias M, Seeberg B, Schannwell M, Welp LB, Schultheiss HP. Chronic inflammation in the myocardium of patients with clinically suspected dilated cardiomyopathy. J Card Fail. 1994;1(1):13-25.

88. Kühl U, Noutsias M, Seeberg B, Schultheiss HP. Immunohistological evidence for a chronic intramyocardial inflammatory process in dilated cardiomyopathy. Heart. 1996;75(3):295-300.

89. Kuhl U, Toussaint H, Ulrich G, Wagner D, Wolff P, Schultheiss HP. Evaluation of immunohistological data for the diagnosis of myocarditis. In: Schultheiss HP. (editor). New concepts of viral heart disease. Berlin, Heidelberg, New York, Tokyo: Springer-Verlag; 1988. p. 325-36.

90. Noutsias M, Seeberg B, Schultheiss HP, Kühl U. Expression of cell adhesion molecules in dilated cardiomyopathy: evidence for endothelial activation in inflammatory cardiomyopathy. Circulation. 1999;99(16):2124-31.

91. Kühl U, Seeberg B, Schultheiss HP, Strauer BE. Immunohistological characterization of infiltrating lymphocytes in biopsies of patients with clinically suspected dilated cardiomyopathy. Eur Heart J. 1994;15 Suppl C:62-7.

92. Wojnicz R, Nowalany-Kozielska E, Wodniecki J, Szczurek-Katanski K, Nozynski J, Zembala M, et al. Immunohistological diagnosis of myocarditis: potential role of sarcolemmal induction of the MHC and ICAM-1 in the detection of autoimmune mediated myocyte injury. Eur Heart J. 1998;19(10):1564-72

93. Maisch B, Portig I, Ristic A, Hufnagel G, Pankuweit S. Definition of inflammatory cardiomyopathy (myocarditis): on the way to consensus: a status report. Herz. 2000;25(3):200-9.

94. Schultz JC, Hilliard AA, Cooper LT Jr, Rihal CS. Diagnosis and treatment of viral myocarditis. Mayo Clin Proc. 2009;84(11):1001-9.

95. Costanzo-Nordin MR, Reap EA, O'Connell JB, Robinson JA, Scanlon PJ. A nonsteroid anti-inflammatory drug exacerbates Coxsackie B3 murine myocarditis. J Am Coll Cardiol. 1985;6(5):1078-82.

96. Cabinian AE, Kiel RJ, Smith F, Ho KL, Khatib R, Reyes MP. Modification of exercise-aggravated coxsackievirus B3 murine myocarditis by Tlymphocyte suppression in an inbred model. J Lab Clin Med. 1990;115(4):454-62.

97. Maron BJ. Sudden death in youngathletes. N EnglJ Med. 2003;349(11):1064-75.

98. Maron BJ, Ackerman MJ, Nishimura RA, Pyeritz RE, Towbin JA, Udelson JE. Task Force 4: HCM and other cardiomyopathies, mitral valve prolapse, myocarditis, and Marfan syndrome. J Am Coll Cardiol. 2005;45(8):1340-5.

99. Schultheiss HP, Kühl U, Cooper LT. The management of myocarditis. Eur Heart J. 2011;32(21):2616-25.

100. Fohlman J, Ilbäck NG, Friman G, Morein B. Vaccination of Balb/c mice against enteroviral mediated myocarditis.Vaccine. 1990;8(4):381-4.

101. Reyes MP, Khatib R, Khatib G, Ho KL, Smith F, Kloner RA. Prolonged captopril therapy in murine viral myocarditis. J Cardiovasc Pharmacol Ther. 1998;3(1):43-50.

102. Xiao J, Shimada M, Liu W, Hu D, Matsumori A. Anti-inflammatory effects of eplerenone on viral myocarditis. Eur J Heart Fail. 2009;11(4):349-53.
103. Anguita-Sánchez M, Castillo-Domínguez JC, Mesa-Rubio D, Ruiz-Ortiz M, López-Granados A, Suárez de Lezo J. [Should angiotensin-converting enzyme inhibitors be continued over the long term in patients whose left ventricular ejection fraction normalizes after an episode of acute myocarditis?]. Rev Esp Cardiol. 2006;59(11):1199-201.

104. Aboukhoudir F, Rekik S, Hirsch JL. Images in cardiovascular medicine. Live echocardiographic visualization of the migration of a voluminous left ventricular thrombus complicating an acute myocarditis. Circulation. 2009;120(2):e8-10.

105. Mason JW, O'Connell JB, Herskowitz A, Rose NR, McManus BM, Billingham ME, et al. A clinical trial of immunosuppressive therapy for myocarditis. The Myocarditis Treatment Trial Investigators. N Engl J Med. 1995;333(5):269-75.

106. Frustaci A, Russo MA, Chimenti C. Randomized study on the efficacy of immunosuppressive therapy in patients with virus-negative inflammatory cardiomyopathy: the TIMIC study. Eur Heart J. 2009;30(16):1995-2002.

107. Frustaci A, Chimenti C, Calabrese F, Pieroni M, Thiene G, Maseri A. Immunosuppressive therapy for active lymphocytic myocarditis virological and immunologic profile of responders versus nonresponders. Circulation. 2003;107(6):857-63.

108. Montera MW, Almeida DR, Mesquita ET, Villacorta H, Mesquita CT, Takiya C, et al. Predictors of left ventricular function improvement after immunosuppression therapy in patients with active lymphocytic myocarditis. J Card Fail. 2004;10(4 Suppl):S82.

109. Maisch B, Pankuweit S, Koelsch S, Hufnagel G, Funck R, Grimm $W$, et al. Sequential analysis of immunosuppressive therapy in autoreactive myocarditis: sequential analysis from ESETCID. Circulation. 2007;116:337-8

110. Stess CS, Khoo MS, Lowery CM, Sauer WH. Ventricular tachycardia storm successfully treated with immunosuppression and catheter ablation in a patient with cardiac sarcoidosis. J Cardiovasc Electrophysiol. $2011 ; 22(2): 210-3$

111. Nunes H, Bouvry D, Soler P, Valeyre D. Sarcoidosis. Orphanet J Rare Dis. $2007 ; 2: 46$.

112. Wijetunga $M$, Rockson S. Myocarditis in systemic lupus erythematosus. Am J Med. 2002;113(5):419-23.

113. Deonarain R, Cerullo D, Fuse K, Liu PP, Fish EN. Protective role for interferonbeta in coxsackievirus B3 infection. Circulation. 2004;110(23):3540-3.

114. Schultheiss HP, Piper C, Sowade O, Karason K, Kapp JF, Wegscheider K, et al. The effect of subcutaneous treatment with interferon-Beta-1B over 24 weeks on safety, virus elimination and clinical outcome in patients with chronic viral cardiomyopathy. Circulation. 2008;118(22):2312.

115. Maisch B, Haake H, Schlotmann S, Funck R, Richter A, Pankuweit S. Intermediate dose of pentaglobin eradicates effectively inflammation in parvo B19 and adenovirus positive myocarditis. Eur Heart). 2008;29(Abstract Supplement):438.

116. Muller J, Wallukat G, Dandel M, Bieda M, Brandes K, Spiegelsberger $\mathrm{S}$, et al. Immunoglobulin adsorption in patients with idiopathic dilated cardiomyopathy. Circulation. 2000;101(4):385-91.

117. Shaw SM, Shah MK, Williams SG, Fildes JE. Immunological mechanisms of pentoxifylline in chronic heart failure. Eur J Heart Fail. 2009;11(2):113-8.

118. Sliwa K, Skudicky D, Candy G, Wisenbaugh T, Sareli P. Randomised investigation of effects of pentoxifylline on left-ventricular performance in idiopathic dilated cardiomyopathy. Lancet. 1998;351(9109):1091-3.

119. Skudicky D, Sliwa K, Bergemann A, Candy G, Sareli P. Reduction in Fas/APO1 plasma concentrations correlates with improvement in left ventricular function in patients with idiopathic dilated cardiomyopathy treated with pentoxifylline. Heart. 2000;84(4):438-9.

120. Skudicky D, Bergemann A, Sliwa K, Candy G, Sareli P. Beneficial effects of pentoxifylline in patients with idiopathic dilated cardiomyopathy treated with angiotensin-converting enzyme inhibitors and carvedilol: results of a randomized study. Circulation. 2001;103(8):1083-8. 
121. Sliwa K, Skudicky D, Candy G, Bergemann A, Hopley M, Sareli P. The addition of pentoxifylline to conventional therapy improves outcome in patients with peripartum cardiomyopathy. Eur J Heart Fail. 2002;4(3):305-9.

122. Gupta S, Markham DW, Drazner MH, Mammen PP. Fulminant myocarditis. Nat Clin Pract Cardiovasc Med. 2008;5(11):693-706.

123. Felker GM, Thompson RE, Hare JM, Hruban RH, Clemetson DE, Howard $\mathrm{DL}$, et al. Underlying causes and long-term survival in patients with initially unexplained cardiomyopathy. N Engl J Med. 2000;342(15):1077-84.

124. McCarthy RE 3rd, Boehmer JP, Hruban RH, Hutchins GM, Kasper EK, Hare $\mathrm{JM}$, et al. Long-term outcome of fulminant myocarditis as compared with acute (nonfulminant) myocarditis. N Engl J Med. 2000;342(10):690-5.

125. Davydow DS, Hough CL. Surviving fulminant myocarditis: is the head the heart of the matter? Crit Care Med. 2011;39(5):1211-3.

126. Goland S, Czer LS, Siegel RJ, Tabak S, Jordan S, Luthringer D, et al. Intravenous immunoglobulin treatment for acute fulminant inflammatory cardiomyopathy: series of six patients and review of literature. Can J Cardiol. 2008;24(7):571-4

127. McNamara DM, Rosenblum WD, Janosko KM, Trost MK, Villaneuva FS, Demetris AJ, et al. Intravenous immune globulin in the therapy of myocarditis and acute cardiomyopathy. Circulation. 1997;95(11):2476-8.

128. Tanawuttiwat T, Trachtenberg BH, Hershberger RE, Hare JM, Cohen MG. Dual percutaneous mechanical circulatory support as a bridge to recovery in fulminant myocarditis. ASAIO J. 2011;57(5):477-9.

129. Sezai A, Hata M, Niino T, Yoda M, Takayama T, Saito S, et al. Mechanical circulatory support for fulminant myocarditis. Surg Today. 2008;38(9):773-7.

130. Dec GW. Recognition of the apical ballooning syndrome in the United States. Circulation. 2005;111(4):388-90.

131. Bybee KA, Prasad A. Stress-related cardiomyopathy syndromes. Circulation. 2008; 118(4):397-409.

132. Bocchi EA, Guimarães G, Tarasoutshi F, Spina G, Mangini S, Bacal F. Cardiomyopathy, adult valve disease and heart failure in South America. Heart. 2009;95(3):181-9.

133. Higuchi M de L, Gutierrez PS, Aiello VD, Palomino S, Bocchi E, Kalil J, et al. Immunohistochemical characterization of infiltrating cells in human chronic chagasic myocarditis: comparison with myocardial rejection process. Virchows Arch A Pathol Anat Histopathol. 1993;423(3):157-60.

134. Melo LM, Souza GE, Valim LR, Moreira LF, Damico EA, Rocha TR, etal. Study of pro-thrombotic and pro-inflammatory factors in Chagas cardiomyopathy. Arq Bras Cardiol. 2010;95(5):655-62.

135. Mangini S, Silveira FS, Silva CP, Grativvol PS, Seguro LF, Ferreira SM, et al. Decompensated heart failure in the emergency department of a cardiology hospital. Arq Bras Cardiol. 2008;90(6):400-6.

136. Bocchi EA. [Update on indications and results of the surgical treatment of heart failure]. Arq Bras Cardiol. 1994;63(6):523-30.

137. Bocchi EA. Exercise training in Chagas' cardiomyopathy: trials are welcome for this neglected heart disease. Eur J Heart Fail. 2010;12(8):782-4.

138. Bellotti G, Bocchi EA, de Moraes AV, Higuchi ML, Barbero-Marcial M, Sosa $\mathrm{E}$, et al. In vivo detection of Trypanosoma cruzi antigens in hearts of patients with chronic Chagas' heart disease. Am HeartJ. 1996;131(2):301-7. Erratum in: Am Heart J. 1998;135(3):550.

139. Higuchi M de L, Kawakami J, Ikegami R, Clementino MB, Kawamoto FM, Reis MM, et al. Do Archaea and bacteria co-infection have a role in the pathogenesis of chronic chagasic cardiopathy? Mem Inst Oswaldo Cruz. 2009;104(Suppl 1):199-207.

140. Bocchi EA, Kalil R, Bacal F, de Lourdes Higuchi M, Meneghetti C, Magalhães A, et al. Magnetic resonance imaging in chronic Chagas' disease: correlation with endomyocardial biopsy findings and Gallium-67 cardiac uptake. Echocardiography. 1998;15(3):279-88.
141. Vilas-Boas F, Feitosa GS, Soares MB, Pinho-Filho JA, Nascimento T, Barojas $\mathrm{MM}$, et al.Invasive and noninvasive correlations of B-type natriuretic peptide in patients with heart failure due to Chagas cardiomyopathy. Congest Heart Fail. 2008;14(3):121-6.

142. Mocelin AO, Issa VS, Bacal F, Guimarães GV, Cunha E, Bocchi EA. The influence of aetiology on inflammatory and neurohumoral activation in patients with severe heart failure: a prospective study comparing Chagas' heart disease and idiopathic dilated cardiomyopathy. Eur J Heart Fail. 2005;7(5):869-73.

143. Issa VS, Bocchi EA. Antitrypanosomal agents: treatment or threat? Lancet. 2010;376(9743):768.

144. Bocchi EA, Cruz F, Guimarães G, Pinho Moreira LF, Issa VS, Ayub Ferreira SM, et al. Long-term prospective, randomized, controlled study using repetitive education at six-month intervals and monitoring for adherence in heart failure out patients: the REMADHE trial. Circ Heart Fail. 2008;1(2):115-24

145. Issa VS, Amaral AF, Cruz FD, Ferreira SM, Guimarães GV, Chizzola $\mathrm{PR}$, et al. Beta-blocker therapy and mortality of patients with Chagas cardiomyopathy: a subanalysis of the REMADHE prospective trial. Circ Heart Fail. 2010;3(1):82-8.

146. Bocchi EA, Bacal F, Guimarães G, Mendroni A, Mocelin A, Filho AE, et al. Granulocyte-colony stimulating factor or granulocyte-colony stimulating factor associated to stem cell intracoronary infusion effects in non ischemic refractory heart failure. Int J Cardiol. 2010;138(1):94-7.

147. Bocchi EA, Marcondes-Braga FG, Ayub-Ferreira SM, Rohde LE, Oliveira WA Almeida DR, et al; Sociedade Brasileira de Cardiologia. III Diretriz Brasileira de Insuficiência Cardíaca Crônica. Arq Bras Cardiol. 2009;93(1 supl 1):1-71.

148. Bocchi EA, Vilas-Boas F, Moreira Mda C, Barretto AC, Lage S, Albuquerque D, et al; Investigators of BELIEF Study; Heart Failure Working Group of Brazilian Society of Cardiology. Levosimendan in decompensated heart failure patients: efficacy in a Brazilian cohort. Results of the BELIEF study. Arq Bras Cardiol. 2008;90(3):182-90.

149. Bocchi EA, Moreira LF, Bellotti G, Barreto AC, Azul LG, Stolf N, et al. Hemodynamic study during upright isotonic exercise before and six months after dynamic cardiomyoplasty for idiopathic dilated cardiomyopathy or Chagas' disease. Am J Cardiol. 1991;67(2):213-4.

150. Moreira LF, Stolf NA, de Lourdes Higuchi M, Bacal F, Bocchi EA, Oliveira SA. Current perspectives of partial left ventriculectomy in the treatment of dilated cardiomyopathy. Eur J Cardiothorac Surg. 2001;19(1):54-60.

151. Bocchi EA, Bellotti G, Moreira LF, Bacal F, de Moraes AV, Fiorelli A, et al. Mid-term results of heart transplantation, cardiomyoplasty, and medical treatment of refractory heart failure caused by idiopathic dilated cardiomyopathy. J Heart Lung Transplant. 1996;15(7):736-45.

152. Bocchi EA, Bellotti G, Uip D, Kalil J, de Lourdes Higuchi M, Fiorelli A, et al. Long-term follow-up after heart transplantation in Chagas' disease. Transplant Proc. 1993;25(1 Pt 2):1329-30.

153. Borghetti-Maio SA, Romano BW, Bocchi EA, Moreira LF, Barreto AC, Stol NA, et al. Quality of life after cardiomyoplasty. J Heart Lung Transplant. 1994:13(2):271-5.

154. Bocchi EA, Fiorelli A; First Guideline Group for Heart Transplantation of the Brazilian Society of Cardiology. The Brazilian experience with heart transplantation: a multicenter report. J Heart Lung Transplant. 2001;20(6):637-45

155. Fiorelli Al, Stolf NA, Honorato R, Bocchi E, Bacal F, Uip D, et al. Late evolution after cardiac transplantation in Chagas' disease. Transplant Proc. 2005:37(6):2793-8

156. Bocchi EA, Vieira ML, Fiorelli A, Hayashida S, Mayzato M, Leirner A, et al. [Hemodynamic and neurohormonal profile during assisted circulation with heterotopic artificial ventricle followed by heart transplantation]. Arq Bras Cardiol. 1994;62(1):23-7.

157. Bocchi EA, Higuchi ML, Vieira ML, Stolf N, Bellotti G, Fiorelli A, et al. Higher incidence of malignant neoplasms after heart transplantation for treatment of chronic Chagas' heart disease. J Heart Lung Transplant. 1998;17(4):399-405. 
158. Bocchi EA, Fiorelli A. The paradox of survival results after heart transplantation for cardiomyopathy caused by Trypanosoma cruzi. First Guidelines Group for Heart Transplantation of the Brazilian Society of Cardiology. Ann Thorac Surg. 2001;71(6):1833-8.

159. Campos SV, Strabelli TM, Amato Neto V, Silva CP, Bacal F, Bocchi EA, et al. Risk factors for Chagas' disease reactivation after heart transplantation. J Heart Lung Transplant. 2008;27(6):597-602.

160. Bacal F, Silva CP, Bocchi EA, Pires PV, Moreira LF, Issa VS, et al. Mychophenolate mofetil increased chagas disease reactivation in heart transplanted patients: comparison between two different protocols. Am J Transplant. 2005;5(8):2017-21.

161. Bocchi EA, Bellotti G, Mocelin AO, Uip D, Bacal F, Higuchi ML, et al. Heart transplantation for chronic Chagas' heart disease. Ann Thorac Surg. 1996;61(6):1727-33

162. Lieberman EB, Hutchins GM, Herskowitz A, Rose NR, Baughman KL. Clinico pathologic description of myocarditis. J Am Coll Cardiol. 1991;18(7):161726.

163. Hare JM, Baughman KL. Fulminant and acute lymphocytic myocarditis: the prognostic value of clinicopathological classification. Eur Heart J. 2001;22(4):269-70.

164. Calabrese F, Rigo E, Milanesi O, Boffa GM, Angelini A, Valente M, et al. Molecular diagnosis of myocarditis and dilated cardiomyopathy in children: clinicopathologic features and prognostic implications. Diagn Mol Pathol. 2002; 11(4):212-21.

165. Meneghini A, Breda JR, Ferreira C. Pericardite aguda. In Serrano Jr CV, Timerman A, Stefanini E. Tratado de cardiologia SOCESP. $2^{a}$ ed. Barueri: Editora Manole; 2009. p. 1961-78.

166. Brady WJ, Perron AD, Martin ML, Beagle C, Aufderheide TP. Cause of ST segment abnormality in ED chest pain patients. Am J Emerg Med. 2001;19(1):25-8.

167. Trouthton RW, Asher CR, Klein AL. Pericarditis. Lancet. 2004;363(9410):717-27.

168. Maisch B, Seferović PM, Ristić AD, Erbel R, Rienmüller R, Adler Y, et al; Task Force on the Diagnosis and Management of Pericardial Diseases of the European Society of Cardiology. Guidelines on the diagnosis and management of pericardial diseases executive summary: The Task force on the diagnosis and management of pericardial diseases of the European Society of Cardiology. Eur Heart J. 2004;25(7):587-610.

169. Goyle KK, Walling AD. Diagnosing pericarditis. Am Fam Physician. 2002;66(9):1695-702.

170. Libby P, Zipes D, Bonow R. Braunwald's heart disease: a textbook of cardiovascular disease. 8th ed. Philadelphia; Elsevier; 2007.

171. Trautner BW, Darouiche RO. Tuberculous pericarditis: optimal diagnosis and management. Clin Infect Dis. 2001;33(7):954-61.

172. Soler-Soler J, Sagristà-Sauleda J, Permanyer-Miralda G. Relapsing pericarditis. Heart. 2004;90(11):1364-8.

173. Permanyer-Miralda G, Sagristà-Sauleda J, Soler-Soler J. Primary acute pericardial disease: a prospective series of 231 consecutive patients. Am J Cardiol. 1985;56(10):623-30.

174. Zayas R, Anguita M, Torres F, Gimenez D, Bergillos F, Ruiz M, et al. Incidence of specific etiology and role of methods for specific etiologic diagnosis of primary acute pericarditis. Am J Cardiol. 1995;75(5):378-82.

175. Sagristà-Sauleda J, Angel J, Sambola A, Alguersuari J, Permanyer-Miralda G, Soler-Soler J. Low-pressure cardiac tamponade: clinical and hemodynamic profile. Circulation. 2006;114(9):945-52.

176. Bonnefoy E, Godon G, Kirkorian G, Fatemi M, Chevalier P, Touboul P. Serum cardiac troponin I and ST-segment elevation in patients with acute pericarditis. Eur Heart J. 2000;21(10):832-6.

177. Brandt RR, Filzmaier K, Hanrath P. Circulating cardiac troponin I in acute pericarditis. Am J Cardiol. 2001;87(11):1326-8.
178. Cohen R, Cohen-Aubart F, Steg PG. [Acute pericarditis in the modern era: a diagnostic challenge]. Ann Cardiol Angeiol (Paris). 2008;57(1):10-5.

179. Imazio M, Brucato A, Maestroni S, Cumetti D, Dominelli A, Natae G, et al. Prevalence of $\mathrm{C}$-reactive protein elevation and time course of normalization in acute pericarditis: implications for the diagnosis, therapy, and prognosis of pericardits. Circulation. 2011;123(10):1092-7.

180. Mady C, Fernandes F, Arteaga E, Ramires FJ, Buck Pde C, Salemi VM, et al. Serum NT pro-BNP: relation to systolic and diastolic function in cardiomyopathies and pericardiopathies. Arq Bras Cardiol. 2008;91(1):46-54.

181. Fernandes F, Almeida IJ, Ramires FJ, Buck PC, Salemi VM, Ianni BM, et al. [NT pro-BNP levels in pericardial diseases and how they are used as complementary evaluation method of diastolic restriction. Initial experience: 25 cases]. Arq Bras Cardiol. 2006;86(3):175-80.

182. Levy PY, Fournier PE, Charrel R, Metras D, Habib G, Raoult D. Molecular analysis of pericardial fluid: a 7-year experience. Eur Heart J. 2006;27(16):1942-6.

183. Imazio M, Brucato A, Doria A, Brambilla G, Ghirardello A, Romito A, et al. Antinuclear antibodies in recurrent idiopathic pericarditis: prevalence and clinical significance. Int J Cardiol. 2009;136(3):289-93.

184. Surawicz B, Lasseter KC. Electrocardiogram in pericarditis. Am J Cardiol. 1970;26(5):471-4.

185. Spodick DH. Diagnostic electrocardiographic sequences in acute pericarditis. Significance of PR segment and PR vector changes. Circulation. 1973;48(3):575-80.

186. Baljepally R, Spodick DH. PR-segment deviation as the initial electrocardiographic response in acute pericarditis. Am J Cardiol. 1998;81(12):1505-6.

187. Bruce MA, Spodick DH. Atypical electrocardiogram in acute pericarditis: characteristics and prevalence. J Electrocardiol. 1980;13(1):61-6.

188. Spodick DH. Arrhythmias during acute pericarditis: a prospective study of 100 consecutive cases. JAMA. 1976;235(1):39-41.

189. Jung HO, Seung KB, Madias JE. Electrocardiographic changes resulting from pericardial effusion drainage. Am J Cardiol. 2010;106(3):437-41.

190. Bruch C, Schmermund A, Dagres N, Bartel T, Caspari G, Sack S, et al. Changes in QRS voltage in cardiac tamponade and pericardial effusion: reversibility after pericardiocentesis and after anti-inflammatory drug treatment. J Am Coll Cardiol. 2001;38(1):219-26.

191. Bashour FA, Cochran PW. The association of electrical alternans with pericardial effusion. Dis Chest. 1963;44:146-53.

192. Lange RA, Hillis LD. Clinical practice: acute pericarditis. N Engl J Med. 2004;351(21):2195-202.

193. Ginzton LE, Laks MM. The differential diagnosis of acute pericarditis from the normal variant: new electrocardiographic criteria. Circulation. 1982;65(5):1004-9.

194. Dalton JC, Pearson RJ Jr, White PD. Constrictive pericarditis: a review and long-term follow-up of 78 cases. Ann Intern Med. 1956;45(3):445-58.

195. Khandaker MH, Espinosa RE, Nishimura RA, Sinak LJ, Hayes SN, Melduni RM, et al. Pericardial disease: diagnosis and management. Mayo Clin Proc. 2010;85(6):572-93.

196. Eisenberg MJ, Dunn MM, Kanth N, Gamsu G, Schiller NB. Diagnostic value of chest radiography for pericardial effusion. J Am Coll Cardiol. 1993;22(2):588-93.

197. Ling LH, Oh JK, Breen JF, Schaff HV, Danielson GK, Mahoney DW, et al. Calcific constrictive pericarditis: is it still with us? Ann Intern Med. 2000;132(6):444-50.

198. LittleWC, Freeman GL. Pericardial disease. Circulation. 2006;113(12):1622-32.

199. Nagueh SF, Appleton CP, Gillebert TC, Marino PN, Oh JK, Smiseth OA, et al. Recommendations for the evaluation of left ventricular diastolic function by echocardiography. J Am Soc Echocardiogr. 2009;22(2):107-33. 
200. Wang Z), Reddy GP, Gotway MB, Yeh BM, Hetts SW, Higgins CB. CT and MR imaging of pericardial disease. Radiographics. 2003;23 Spec No:S167-80.

201. Goldstein JA. Cardiac tamponade, constrictive pericarditis, and restrictive cardiomyopathy. Curr Probl Cardiol. 2004;29(9):503-67.

202. Talreja DR, Edwards WD, Danielson GK, Schaff HV, Tajik AJ, Tazelaar HD, et al. Constrictive pericarditis in 26 patients with histologically normal pericardial thickness. Circulation. 2003;108(15):1852-7.

203. Oh KY, Shimizu M, Edwards WD, Tazelaar HD, Danielson GK. Surgical pathology of the parietal pericardium: a study of 344 cases (1993-1999). Cardiovasc Pathol. 2001;10(4):157-68.

204. Dakik HA, Hourani M, Bazarbachi A. Scintigraphic imaging of pericarditis. Clin Cardiol. 2009;32(11):E89.

205. James OG, Christensen JD, Wong TZ, Borges-Neto S, Koweek LM. Utility of FDG PET/CT in inflammatory cardiovascular disease. Radiographics. 2011;31(5):1271-86.

206. Khandaker MH, Espinosa RE, Nishimura RA, Sinak LJ, Hayes SN, Melduni RM, et al. Pericardial disease: diagnosis and management. Mayo Clin Proc. 2010;85(6):572-93.

207. Spodick DH. Pericardial diseases. In: Braunwald E, Zippes DP, Libby P. (editors). Heart disease. 6th ed. Philadelphia, London, Toronto, Montreal Sydney, Tokyo: W.B. Saunders; 2001. p. 1823-76.

208. Sagristà-Sauleda J, Angel J, Permanyer-Miralda G, Soler-Soler J. Longterm follow-up of idiopathic chronic pericardial effusion. N Engl J Med. 1999;341(27):2054-9.

209. Fernandes F, lanni BM, Arteaga E, Benvenutti L, Mady C. [Value of pericardial biopsy in the etiologic diagnosis of pericardial diseases]. Arq Bras Cardiol. 1998;70(6):393-5.

210. Labovitz AJ, Noble VE, Bierig M, Goldstein SA, Jones R, Kort S, et al. Focused cardiac ultrasound in the emergent setting: a consensus statement of the American Society of Echocardiography and American College of Emergency Physicians. J Am Soc Echocardiogr. 2010;23(12):1225-30.

211. Sagristà-Sauleda J, Angel J, Sánchez A, Permanyer-Miralda G, Soler-Soler J. Effusive-constrictive pericarditis. N Engl J Med. 2004;350(5):469-75.

212. Pêgo-Fernandes PM, Mariani AW, Fernandes F, lanni BM, Stolf NG, Jatene $\mathrm{FB}$. The role of videopericardioscopy in evaluating indeterminate pericardial effusions. Heart Surg Forum. 2008;11(1):E62-5.

213. Maisch B, Ristic AD, Rupp H, Spodick DH. Pericardial access using the PerDUCER and flexible percutaneous pericardioscopy. Am J Cardiol. 2001;88(11):1323-6.

214. Seferovic PM, Ristic AD, Maksimovic R, Tatic V, Ostojic M, Kanjuh V. Diagnostic value of pericardial biopsy: improvement with extensive sampling enabled by pericardioscopy. Circulation. 2003;107(7):978-83 .

215. Maisch B, Pankuweit S, Brilla C, Funck RC, Simon BC, Grimm W, et al. Intrapericardial treatment of inflammatory and neoplastic pericarditis guided by pericardioscopy and epicardial biopsy - results from a pilot study. Clin Cardiol.1999;22(1 Suppl 1):117-22.

216. Maisch B, Ristic AD, PankuweitS, Neubauer A, Moll R. Neoplastic pericardial effusion: efficacy and safety of intrapericardial treatment with cisplatin. Eur Heart J. 2002;23(20):1625-31.

217.Levy R, Najioullah F, Thouvenot D, Bosshard S, Aymard M, Lina B. Evaluation and comparison of PCR and hybridization methods for rapid detection of cytomegalovirus in clinical samples. J Virol Methods. 1996;62(2):103-11.

218. Satoh T, Kojima M, Ohshima K. Demonstration of the Epstein-Barr genome by the polymerase chain reaction and in situ hybridisation in a patient with viral pericarditis. Br Heart J. 1993;69(6):563-4

219. Andreoletti L, Hober D, Belaich S, Lobert PE, Dewilde A, Wattre P. Rapid detection of enterovirus in clinical specimens using PCR and microwell capture hybridization assay. J Virol Methods. 1996;62(1):1-10.
220. Maisch B, Bethge C, Drude L, Hufnagel G, Herzum M, Schonian U. Pericardioscopy and epicardial biopsy: new diagnostic tools in pericardial and perimyocardial diseases. Eur Heart J. 1994;15 Suppl C:68-73.

221. Maisch B, Ristic AD, Pankuweit S. Intrapericardial treatment of autoreactive pericardial effusion with triamcinolone: the way to avoid side effects of systemic corticosteroid therapy. Eur Heart J. 2002;23(19):1503-8.

222. Adler Y, Finkelstein Y, Guindo J, Rodriguez de la Serna A, Shoenfeld Y, BayesGenis A, et al. Colchicine treatment for recurrent pericarditis: a decade of experience. Circulation. 1998;97(21):2183-5.

223. Imazio M, Demichelis B, Parrini I, Giuggia M, Cecchi E, Gaschino G, et al. Day-hospital treatment of acute pericarditis: a management program for outpatient therapy. J Am Coll Cardiol. 2004;43(6):1042-6.

224. Spodick DH. Acute pericarditis: current concepts and practice. JAMA. 2003;289(9):1150-3

225. Schifferdecker B, Spodick DH. Nonsteroidal anti-inflammatory drugs in the treatment of pericarditis. Cardiol Rev. 2003;11(4):211-7.

226. Jugdutt $\mathrm{BI}$, Basualdo CA. Myocardial infarct expansion during indomethacin or ibuprofen therapy for symptomatic post infarction pericarditis: influence of other pharmacologic agents during early remodelling. Can J Cardiol. 1989;5(4):211-21.

227. Shabetai R. Recurrent pericarditis: recent advances and remaining questions. Circulation. 2005;112(13):1921-3.

228. Adler Y, Zandman-Goddard G, Ravid M, Avidan B, Zemer D, Ehrenfeld M, et al. Usefulness of colchicine in preventing recurrences of pericarditis. Am J Cardiol. 1994;73(12):916-7.

229. Imazio M, Bobbio M, Cecchi E, Demarie D, Demichelis B, Pomari F, et al. Colchicine in addition to conventional therapy for acute pericarditis: results of the COlchicine for acute PEricarditis (COPE) trial. Circulation. 2005;112(13):2012-6.

230. Imazio M, Bobbio M, Cecchi E, Demarie D, Pomari F, Moratti M, et al. Colchicine as first choice therapy for recurrent pericarditis: results of the CORE (COlchicine for REcurrent pericarditis) trial. Arch Intern Med. 2005;165(17):1987-91

231. Brucato A, Brambilla, Adler Y, Spodick DH, Canesi B. Therapy for recurrent acute pericarditis: a rheumatological solution? Clin Exp Rheumatol. 2006;24(1):45-50.

232. Imazio M, Brucato A, Adler Y, Brambilla G, Artom G, Cecchi E, et al. Prognosis of idiopathic recurrent pericarditis as determined from previously published reports. Am J Cardiol. 2007;100(6):1026-8.

233. Lange U, Schumann C, Schmidt KL. Current aspects of colchicine therapy- classical indications and new therapeutic uses. Eur J Med Res. 2001;6(4):150-60.

234. Wilbur K, Makowsky M. Colchicine myotoxicity: case reports and literature review. Pharmacotherapy. 2004;24(12):1784-92.

235. Terkeltaub RA. Colchicine update: 2008. Semin Arthritis Rheum. 2009;38(6):411-9.

236. Artom G, Koren-Morag N, Spodick DH, Brucato A, Guindo J, Bayes-deLuna A, et al. Pretreatment with corticosteroids attenuates the efficacy of colchicine in preventing recurrent pericarditis: a multicentre all-case analysis. Eur Heart J. 2005;26(7):723-7.

237. Spodick DH. Intrapericardial treatment of persistent autoreactive pericarditis/myopericarditis and pericardial effusion. Eur Heart J. 2002;23(19):1481-2.

238. Asplen CH, Levine HD. Azathioprine therapy of steroid-responsive pericarditis. Am Heart J. 1970;80(1):109-11.

239. Imazio M, Brucato A, Cumetti D, Brambilla G, Demichelis B, Ferro S, et al. Corticosteroids for recurrent pericarditis high versus low doses: nonrandomized observation. Circulation. 2008;118(6):667-71. 
240. Peterlana D, Puccetti A, Simeoni S, Tinazzi E, Corrocher R, Lunardi C. Efficacy of intravenous immunoglobulin in chronic idiopathic pericarditis: report of four cases. Clin Rheumatol. 2005;24(1):18-21.

241. Maisch B, Ristic AD, Seferovic PM. New directions in diagnosis and treatment of pericardial disease: a project of the Taskforce on Pericardial Disease of the World Heart Federation. Herz. 2000;25(8):769-80.

242. Uramoto H, Hanagiri T. Video-assisted thoracoscopic pericardiectomy for malignant pericardial effusion. Anticancer Res. 2010;30(11):4691-4.

243. Traylor JJ, Chan K, Wong I, Roxas JN, Chandraratna PA. Large pleural effusions producing signs of cardiac tamponade resolved by thoracentesis. Am J Cardiol. 2002;89(1):106-8.

244. Tirilomis T, Univerdoben S, von der Emde J. Pericardiectomy for chronic constrictive pericarditis: risks and outcome. Eur J Cardiothorac Surg. 1994;8(9):487-92.

245. Kuroda H, Sakaguchi M, Takano T, Tsunemoto H, Shinohara M, Fukaya Y, et al. Intraoperative monitoring of pressure-volume loops of the left ventricle in pericardiectomy for constrictive pericarditis. J Thorac Cardiovasc Surg. 1996;112(1):198-9.

246. McCaughan BC, Schaff HV, Piehler JM, Danielson GK, Orszulak TA, Puga FJ, et al. Early and late results of pericardiectomy for constrictive pericarditis. J Thorac Cardiovasc Surg. 1985;89(3):340-50.

247. Seifert FC, Miller DC, Oesterle SN, Oyer PE, Stinson EB, Shumway NE. Surgical treatment of constrictive pericarditis: analysis of outcome and diagnostic error. Circulation. 1985;72(3 Pt 2):II264-73.

248. Ni Y, von Segesser LK, Turina M. Futility of pericardiectomy for postirradiation constrictive pericarditis? Ann Thorac Surg. 1990;149(3):445-8.

249. Bertog SC, Thambidorai SK, Parakh K, Schoenhagen P, Ozduran V, Houghtaling PL, et al. Constrictive pericarditis: etiology and cause-specific survival after pericardiectomy. J Am Coll Cardiol. 2004;43(8):1445-52.

250. Sagristà-Sauleda J, Mercé AS, Soler-Soler J. Diagnosis and management of pericardial effusion. World J Cardiol. 2011;3(5):135-43.

251. Rostand SG, Brunzell JD, Cannon RO 3rd, Victor RG. Cardiovascular complications in renal failure. J Am Soc Nephrol. 1991;2(6):1053-62.

252. Jiamsripong P, Mookadam F, Oh JK, Khandheria BK. Spectrum of pericardial disease: part II. Expert Rev Cardiovasc Ther. 2009;7(9):1159-69.

253. Alpert MA, Ravenscraft MD. Pericardial involvement in end-stage renal disease. Am J Med Sci. 2003;325(4):228-36

254. Kleynberg RL, Kleynberg VM, Kleynberg LM, Farahmandian D. Chronic constrictive pericarditis in association with end-stage renal disease. Int J Nephrol. 2011;2011:469602.

255. Connors JP, Kleiger RE, Shaw RC, Voiles JD, Clark RE, Harter H, et al. The indications for pericardiectomy in the uremic pericardial effusion. Surgery. 1976;80(6):689-94.

256. Markel G, Imazio M, Brucato A, Adler Y. Colchicine for the prevention of recurrent pericarditis. Isr Med Assoc J. 2008;10(1):69-72.

257. Lindsay J Jr, Crawley IS, Calloway GM Jr. Chronic constrictive pericarditis following uremic hemopericardium . Am Heart J. 1970;79(3):390-5.

258. Banerjee A, Davenport A. Changing patterns of pericardial disease in patients with end-stage renal disease. Hemodial Int. 2006;10(3):249-55.

259. Prince SE, Cunha BA. Postpericardiotomy syndrome. Heart Lung. 1997;26(2):165-8.

260. Khan AH. The postcardiac injury syndromes. Clin Cardiol. 1992;15(2):67-72.

261. Imazio M, Brucato A, Markel G, Cemin R, Trinchero R, Spodick DH, et al. Meta-analysis of randomized trials focusing on prevention of the postpericardiotomy syndrome. Am J Cardiol. 2011;108(4):575-9.

262. Ashikhmina EA, Schaff HV, Sinak LJ, Li Z, Dearani JA, Suri RM, et al. Pericardial effusion after cardiac surgery: risk factors, patient profiles, and contemporary management. Ann Thorac Surg. 2010;89(1):112-8.
263. Imazio M, Trinchero R, Brucato A, Rovere ME, Gandino A, Cemin R, et al. COlchicine for the Prevention of the Post-pericardiotomy Syndrome (COPPS): a multicentre, randomized, double-blind, placebo-controlled trial. Eur Heart J. 2010;31(22):2749-54.

264. Cocco G, Chu DC, Pandolfi S. Colchicine in clinical medicine: a guide for internists. Eur J Intern Med. 2010;21(6):503-8.

265. Maisch B, Ristic A, Pankuweit S. Evaluation and management of pericardial effusion in patients with neoplastic disease. Prog Cardiovasc Dis. 2010;53(2):157-63.

266. Balghith M, Taylor DA, Jugdutt BI. Cardiac tamponade as the first clinical manifestation of metastatic adenocarcinoma of the lung. Can J Cardiol. 2000;16(7):925-7.

267. Lestuzzi C. Neoplastic pericardial disease: old and current strategies for diagnosis and management. World J Cardiol. 2010;2(9):270-9.

268. Kunitoh H, Tamura T, Shibata T, Imai M, Nishiwaki Y, Nishio M, et al; JCOG Lung Cancer Study Group, Tokyo, Japan. A randomised trial of intrapericardial bleomycin for malignant pericardial effusion with lung cancer (JCOG9811). Br J Cancer. 2009;100(3):464-9.

269. Kim SH, Kwak MH, Park S, Kim HJ, Lee HS, Kim MS, et al. Clinical characteristics of malignant pericardial effusion associated with recurrence and survival. Cancer Res Treat. 2010;42(4):210-6.

270. Ewer MS, Ewer SM. Cardiotoxicity of anticancer treatments: what the cardiologist needs to know. Nat Rev Cardiol. 2010;7(10):564-75.

271. Fowler NO. Tuberculous pericarditis. JAMA. 1991;266(1):99-103.

272. Sagristà-Sauleda J, Permanyer-Miralda G, Soler-Soler J. Tuberculous pericarditis: ten year experience with a prospective protocol for diagnosis and treatment. J Am Coll Cardiol. 1988;11(4):724-8.

273. Ortbals DW, Avioli LV. Tuberculous pericarditis. Arch Intern Med. $1979 ; 139(2): 231-4$.

274. Long R, Younes M, Patton N, Hershfield E. Tuberculous pericarditis: longterm outcome in patients who received medical therapy alone. Am Heart J. 1989;117(5):1133-9.

275. Fowler NO, Manitsas GT. Infectious pericarditis. Prog Cardiovasc Dis. $1973 ; 16(3): 323-36$.

276. Porte HL, Janecki-Delebecq TJ, Finzi L, Métois DG, Millaire A, Wurtz AJ. Pericardioscopy for primary management of pericardial effusion in cancer patients. Eur J Cardiothorac Surg. 1999;16(3):287-91.

277. Ewer K, Deeks J, Alvarez L, Bryant G, Waller S, Andersen P, et al. Comparison of T-cell-based assay with tuberculin skin test for diagnosis of Mycobacterium tuberculosis infection in a school tuberculosis outbreak. Lancet. 2003;361(9364):1168-73.

278. Reuter H, Burgess L, van Vuuren W, Doubell A. Diagnosing tuberculous pericarditis. QJM. 2006;99(12):827-39.

279. Lee JH, Lee CW, Lee SG, Yang HS, Hong MK, Kim JJ, et al. Comparison of polymerase chain reaction with adenosine deaminase activity in pericardial fluid for the diagnosis of tuberculous pericarditis. Am J Med. $2002 ; 113(6): 519-21$.

280. Piersimoni C, Scarparo C. Relevance of commercial amplification methods for direct detection of Mycobacterium tuberculosis complex in clinical samples. J Clin Microbiol. 2003;41(12):5355-65.

281. Nugue O, Millaire A, Porte H, de Groote P, Guimier P, Wurtz A, et al. Pericardioscopy in the etiologic diagnosis of pericardial effusion in 141 consecutive patients. Circulation. 1996;94(7):1635-41.

282. Koh KK, Kim EJ, Cho CH, Choi MJ, Cho SK, Kim SS, et al. Adenosine deaminase and carcinoembryonic antigen in pericardial effusion diagnosis, especially in suspected tuberculous pericarditis. Circulation. 1994;89(6):2728-35.

283. Strang JI, Kakaza HH, Gibson DG, Allen BW, Mitchison DA, Evans DJ, et al. Controlled clinical trial of complete open surgical drainage and of prednisolone in treatment of tuberculous pericardial effusion in Transkei. Lancet. 1988;2(8614):759-64. 
284. Dwivedi SK, Rastogi P, Saran RK, Narain VS, Puri VK, Hasan M. Antitubercular treatment does not prevent constriction in chronic pericardial effusion of undetermined etiology: a randomized trial. Indian HeartJ. 1997;49(4):411-4.

285. Alzeer AH, FitzGerald JM. Corticosteroids and tuberculosis: risks and use as adjunct therapy. Tuber Lung Dis. 1993;74(1):6-11.

286. Mayosi BM, Ntsekhe M, Volmink JA, Commerford PJ. Interventions for treating tuberculous pericarditis. Cochrane Database Syst Rev. 2002;(4):CD000526.

287. Strang JI. Rapid resolution of tuberculous pericardial effusions with high dose prednisone and anti-tuberculous drugs. J Infect. 1994;28(3):251-4 .

288. Blumberg HM, Burman WJ, Chaisson RE, Daley CL, Etkind SC, Friedman LN etal. American Thoracic Society, Centers for Disease Control and Prevention and the Infectious Diseases Society. American Thoracic Society/Centers for Disease Control and Prevention/Infectious Diseases Society of America: treatment of tuberculosis. Am J Respir Crit Care Med. 2003;167(4):603-62.

289. Parikh SV, Memon N, Echols M, Shah J, McGuire DK, Keeley EC. Purulent pericarditis: report of 2 cases and review of the literature. Medicine (Baltimore). 2009;88(1):52-65.

290. Skiest DJ, Steiner D, Werner M, Garner JG. Anaerobic pericarditis: case report and review. Clin Infect Dis. 1994;19(3):435-40.

291. Majid AA, Omar A. Diagnosis and management of purulent pericarditis: experience with pericardiectomy. J Thorac Cardiovasc Surg. 1991;102(3):413-7.

292. Imazio M, Mayosi BM, Brucato A, Markel G, Trinchero R, Spodick DH, et al. Triage and management of pericardial effusion. J Cardiovasc Med (Hagerstown). 2010;11(12):928-35.

293. Imazio M, Brucato A, Mayosi BM, Derosa FG, Lestuzzi C, Macor A, et al. Medical therapy of pericardial diseases: part I: idiopathic and infectious pericarditis. J Cardiovasc Med (Hagerstown). 2010;11(10):712-22.

294. Tomkowski WZ, Gralec R, Kuca P, Burakowski J, Orłowski T, Kurzyna M. Effectiveness of intrapericardial administration of streptokinase in purulent pericarditis. Herz. 2004;29(8):802-5

295. Augustin P, Desmard M, Mordant P, Lasocki S, Maury JM, Heming N, et al. Clinical review: intrapericardial fibrinolysis in management of purulent pericarditis. Crit Care. 2011;15(2):220.

296. Rose NR. Recurrent pericarditis: an autoimmune disease? Heart. 2010;96(10):734-5

297. Haley JH, Tajik AJ, Danielson GK, Schaff HV, Mulvagh SL, Oh JK. Transient constrictive pericarditis: causes and natural history. J Am Coll Cardiol. 2004;43(2):271-5

298. Caforio AL, Brucato A, Doria A, Brambilla G, Angelini A, Ghirardello $\mathrm{A}$, et al. Anti-heart and anti-intercalated disk autoantibodies: evidence for autoimmunity in idiopathic recurrent acute pericarditis. Heart. 2010;96(10):779-84.

299. Maisch B, Ristic AD, Seferovic PM, Spodick DH. Intrapericardial treatment of autoreactive myocarditis with triamcinolon: successful administration in patients with minimal pericardial effusion. Herz. 2000;25(8):781-6.

300. Frank H, Globits S. Magnetic resonance imaging evaluation of myocardial and pericardial disease. J Magn Reson Imaging. 1999;10(5):617-26.

301. Weyne A, Lampaert A, Clement D. Chyle: a masquerading etiology of pericardial effusion. Int J Cardiol. 1987;14(1):106-9.

302. Gabriel Martínez J, Marco E, Marín F, Ibáñez A, Quiles JA, Cabezas A, et al. [Chylopericardium after acute pericarditis]. Rev Esp Cardiol. 1996;49(3):226-8

303. Scholten C, Staudacher M, Girsch W, Wolf G, Grimm M, Binder T, et al. A novel therapeutic strategy for the management of idiopathic chylopericardium and chylothorax. Surgery. 1998;123(3):369-70.

304. Kabadi UM, Kumar SP. Pericardial effusion in primary hypothyroidism. Am Heart J. 1990;120(6 Pt 1):1393-5.
305. Lee $\mathrm{KO}$, Choo MH. Low voltage electrocardiogram with tachycardia in hypothyroidism--a warning sign of cardiac tamponade. Ann Acad Med Singapore. 1993;22(6):945-7.

306. Gregoratos G. Pericardial involvement in acute myocardial infarction. Cardiol Clin. 1990;8(4):601-8.

307. Shahar A, Hod H, Barabash GM, Kaplinsky E, Motro M. Disappearance of a syndrome: Dressler's syndrome in the era of thrombolysis. Cardiology. 1994;85(3-4):255-8.

308. Indik JH, AlpertJS. Post-myocardial infarction pericarditis. Curr Treat Options Cardiovasc Med. 2000;2(4):351-6.

309. Berman J, Haffajee Cl, Alpert JS. Therapy of symptomatic pericarditis after myocardial infarction: retrospective and prospective studies of aspirin indomethacin, prednisone, and spontaneous resolution. Am Heart J. $1981 ; 101(6): 750-3$

310. Imazio M, Brucato A, Trinchero R, SpodickD, Adler Y. Individualized therapy for pericarditis. Expert Rev Cardiovasc Ther. 2009;7(8):965-75.

311. Boden WE, Sadaniantz A. Ventricular septal rupture during ibuprofen therapy for pericarditis after acute myocardial infarction. Am J Cardiol. 1988;55(13 Pt 1):1631-2.

312. Eppert A. Towards evidence-based emergency medicine: best BETs from the Manchester Royal Infirmary. BET 3: colchicine as an adjunct to nonsteroidal anti-inflammatory drugs for the treatment of acute pericarditis. Emerg Med J. $2011 ; 28(3): 244-5$

313. Lotrionte M, Biondi-Zoccai G, Imazio M, Castagno D, Moretti C, Abbate A et al. International collaborative systematic review of controlled clinical trials on pharmacologic treatments for acute pericarditis and its recurrences. Am Heart J. 2010;160(4):662-70.

314. Corallo S, Mutinelli MR, Moroni M, Lazzarin A, Celano V, Repossini A, et al. Echocardiography detects myocardial damage in AIDS: prospective study in 102 patients. Eur Heart J. 1988;9(8):887-92.

315. Himelman RB, Chung WS, Chernoff DN, Schiller NB, Hollander H. Cardiac manifestations of human immunodeficiency virus infection: a two-dimensional echocardiographic study. J Am Coll Cardiol. 1989;13(5):1030-6.

316. De Castro S, Migliau G, Silvestri A, D'Amati G, Giannantoni P, Cartoni D, et al. Heart involvement in AIDS: a prospective study during various stages of the disease. Eur Heart J. 1992;13(11):1452-9.

317. Heidenreich PA, Eisenberg MJ, Kee LL, Somelofski CA, Hollander H, Schille NB, et al. Pericardial effusion in AIDS: incidence and survival. Circulation. 1995:92(11):3229-34.

318. Estok L, Wallach F. Cardiac tamponade in a patient with AIDS: a review of pericardial disease in patients with HIV infection. Mt Sinai J Med. 1998;65(1):33-9

319. Maher D, Harries AD. Tuberculous pericardial effusion: a prospective clinical study in a low-resource setting--Blantyre, Malawi. Int J Tuberc Lung Dis. 1997:1(4):358-64.

320. Dronda F, Suzacq C. [Pericardial tuberculosis complicated with heart tamponade as presentation form of acquired immunodeficiency syndrome]. Rev Clin Esp. 1997;197(7):502-6.

321. Nogueira G, Macedo AJ, Paixão A, Nunes MA, Ferreira M, Bernardino L, et al. [Cardiovascular morbidity in children with human immunodeficiency virus infection]. Acta Med Port. 1998;11(12):1051-7.

322. Sá I, Môço R, Cabral S, Reis AH, Pereira LS, Torres S, et al. Constrictive pericarditis of tuberculous etiology in the HIV-positive patient: case report and review of the literature. Rev Port Cardiol. 2006;25(11):1029-38.

323. Sudano I, Spieker LE, Noll G, Corti R, Weber R, Lüscher TF. Cardiovascular disease in HIV infection. Am Heart J. 2006;151(6):1147-55.

324. Ntsekhe M, Mayosi BM. Cardiac manifestations of HIV infection: an African perspective. Nat Clin Pract Cardiovasc Med. 2009;6(2):120-7. 


\section{Diretrizes}

325. Campbell PT, Li JS, Wall TC, O'Connor CM, Van Trigt P, Kenney RT, et al. Cytomegalovirus pericarditis: a case series and review of the literature. Am J Med Sci. 1995;309(4):229-34.

326. Acierno LJ. Cardiac complications in acquired immunodeficiency syndrome (AIDS): a review. J Am Coll Cardiol. 1989;13(5):1144-54.

327. Small PM, Schecter GF, Goodman PC, Sande MA, Chaisson RE, Hopewell PC. Treatment of tuberculosis in patients with advanced human immunodeficiency virus infection. N Engl J Med. 1991;324(5):289-94.

328. Sunderam G, McDonald RJ, Maniatis T, Oleske J, Kapila R, Reichman LB Tuberculosis as a manifestation of the acquired immunodeficiency syndrome (AIDS). JAMA. 1986;256(3):362-6.

329. Syed FF, Mayosi BM. A modern approach to tuberculous pericarditis. Prog Cardiovasc Dis. 2007;50(3):218-36

330. Nienaber CA, von Kodolitsch Y, Nicolas V, Siglow V, Piepho A, Brockhoff C, et al. The diagnosis of thoracic aortic dissection by noninvasive imaging procedures. N Engl J Med. 1993;328(1):1-9
331.Erbel R, Alfonso F, Boileau C, Dirsch O, Eber B, Haverich $A$, et al. Diagnosis and management of aortic dissection. Eur Heart J. 2001;22(18):1642-81.

332. Mellwig KP, Vogt J, Schmidt HK, Gleichmann U, Minami K, Körfer R. [Acute aortic dissection (Stanford A) with pericardial tamponade - extension of the dissection after emergency pericardial puncture]. Z Kardiol. 1998;87(6):482-6

333. Imazio M, Brucato A, Cemin R, Ferrua S, Belli R, Maestroni S, et al: CORP (COlchicine for Recurrent Pericarditis) Investigators. Colchicine for recurrent pericarditis (CORP): a randomized trial. Ann Intern Med. 2011;155(7):409-14.

334. Miller JI, Mansour KA, Hatcher CR Jr. Pericardiectomy: current indications, concepts, and results in a university center. Ann Thorac Surg. $1982 ; 34(1): 40-5$.

335. Hatcher CR Jr, Logue RB, Logan WD Jr, Symbas PN, Mansour KA, Abbott OA. Pericardiectomy for recurrent pericarditis. J Thorac Cardiovasc Surg. 1971;62(3):371-8. 